\title{
Dosso Dossi, Garofalo, and the Costabili Polyptych: Imaging Spiritual Authority
}

\author{
Giancarlo Fiorenza
}

In the 1568 edition of his Life of the Ferrarese painter Benvenuto Tisi, called Garofalo (ca. 1476 or 1481-1559), Giorgio Vasari provides a detailed account of the artist's education and early career, including specific information on the genesis of the extraordinary Costabili polyptych (with frame, 31 feet 6 inches by 18 feet 11 inches, or 9.6 by 5.8 meters), now in the Pinacoteca Nazionale of Ferrara (Fig. 1). ${ }^{1}$ The dating of the Costabili polyptych, which Garofalo executed in collaboration with the artist Giovanni di Niccolò de Luteri, known as Dosso Dossi (ca. 1486?-1542), lies at the center of a controversy. One art historian has recently stated that the entire chronology of northern Italian painting in the early sixteenth century hinges on knowing precisely when these two artists achieved the stylistic innovations exhibited by the polyptych-from the textural complexities to the embellishment of bodily form. ${ }^{2}$ Since questions of artistic choice have direct bearing on the experience and historical status of the image, Vasari's early reception of the Costabili polyptych is primary in the establishment of a contextual framework. It is important to note that Vasari met Garofalo personally during his two visits to Ferrara between 1540 and 1542, gaining firsthand information on the artist's work. ${ }^{3}$ Vasari relates that Garofalo had been called back to Ferrara from his sojourn in Rome, where he had studied under Raphael, in order to decorate a small chapel in the ducal castle (this probably occurred toward the end of 1512). ${ }^{4}$ Once he had completed this project ("[1]a quale finita"), the artist took up the commission to paint the polyptych for Antonio Costabili (ca. 1450-1527), the chief magistrate (giudice) of the communal magistracy known as the Dodici Savi of Ferrara. Only after fulfilling his obligations for the giudice's polyptych ("[1]a quale finita") did Garofalo begin work on several other pressing commissions in the city, including an altarpiece for the church of S. Spirito, which Vasari describes as follows: "the Virgin in the air with the Child in her arms, and below some other figures."5 This is unquestionably Garofalo's celebrated Suxena Altarpiece, now also in the Pinacoteca Nazionale of Ferrara, which has a provenance from S. Spirito, in the chapel of the Immaculate Conception patronized by the Suxena family of Ferrara (Fig. 2) ${ }^{6}$ It is well known that Garofalo imitated the composition of Raphael's Madonna di Foligno of 1512 for his own altarpiece, which shows the Virgin and Child appearing in the clouds above Saints Jerome and Francis and two donors, who kneel in worship before a magnificent landscape. Garofalo dated the Suxena Altarpiece December 1514-a date that strongly implies the Costabili polyptych was completed by the end of that year. ${ }^{7}$

Vasari's chronology agrees with a series of payments to Garofalo and Dosso recorded in the municipal ledger, or zornale, of the Commune of Ferrara (now housed in the Archivio di Stato of Ferrara); these payments have been published recently by Adriano Franceschini. ${ }^{8}$ The first docu- ment, dated July 11, 1513, indicates that Antonio Costabili had commissioned Dosso and Garofalo to paint a polyptych for the high altar of the church of S. Andrea in Ferrara (now in ruins), at that time occupied by the Eremitani friars of the Augustinian order. ${ }^{9}$ According to the initial payment, work was already in progress on the altarpiece ("de una tavola che depinzono"). A reimbursement to the artists on August 6, 1513, for the purchase of costly pigments in Venice, and interim payments on November 15 and 21 totaling 210 lire marchesane, suggest that Dosso and Garofalo worked continuously and closely together on the enormous Costabili polyptych. ${ }^{10}$ Early sources confirm that Costabili possessed the patronage rights for the high altar and chancel of S. Andrea, his parish church, and that his altarpiece stood in the back of the chancel raised above the choir stalls. ${ }^{11}$ Unfortunately, the municipal registers for 1514 and the following years are largely missing from the archives, thereby leaving Vasari's implicit date of completion for this imposing work open to question.

The Costabili polyptych still retains its original frame, albeit reconstructed after suffering severe damage during World War II. The towering central panel is set within a classical arch and shows the Virgin and Child enthroned, with the infant Saint John the Baptist to one side. A number of saints gather at the foot of the throne: those securely identifiable are Saint Andrew, the patron saint of the church, who bears a cross and gestures toward the Virgin; Saint Jerome, who holds an open book while resting his foot on a skull; and the youthful John the Evangelist, who, sitting cross-legged on the steps of the Virgin's throne, turns to address her as he pauses from writing his Gospel. The angels who float in the clouds above support the luxurious tapestry adorning the Madonna's high-backed throne, while several spiritelli, ${ }^{12}$ in a motif echoed in the Suxena Altarpiece, display folios with citations from the Vulgate Book of Isaiah 9:6 written in bold majuscules: DEUS FORTIS; PRINCEPS PACIS. These phrases are unprecedented in Ferrarese painting, and a major part of this study will be devoted to determining their meaning within the framework of the polyptych. ${ }^{13} \mathrm{~A}$ pronounced display of chiaroscuro enshrouds the entire composition, and its dramatic effect is especially prominent in the lower side panels depicting Saints George, the patron saint of Ferrara, and Sebastian, another Christian soldier. In the spandrel above Saint George sits Saint Augustine, who appears as a hermit dressed in the habit of the Eremitani (also known as the Austin friars), wearing a scapular, his bishop's miter resting at his feet. While the saint's dress denotes the eremitic character of the order of friars at S. Andrea, a remarkable and unexampled feature is the fiery red halo shining around Augustine's head. Equally arresting is the rain of fire shooting from within the interior of the cell that the saint points to urgently. The significance of these details has never been fully explained and demands 


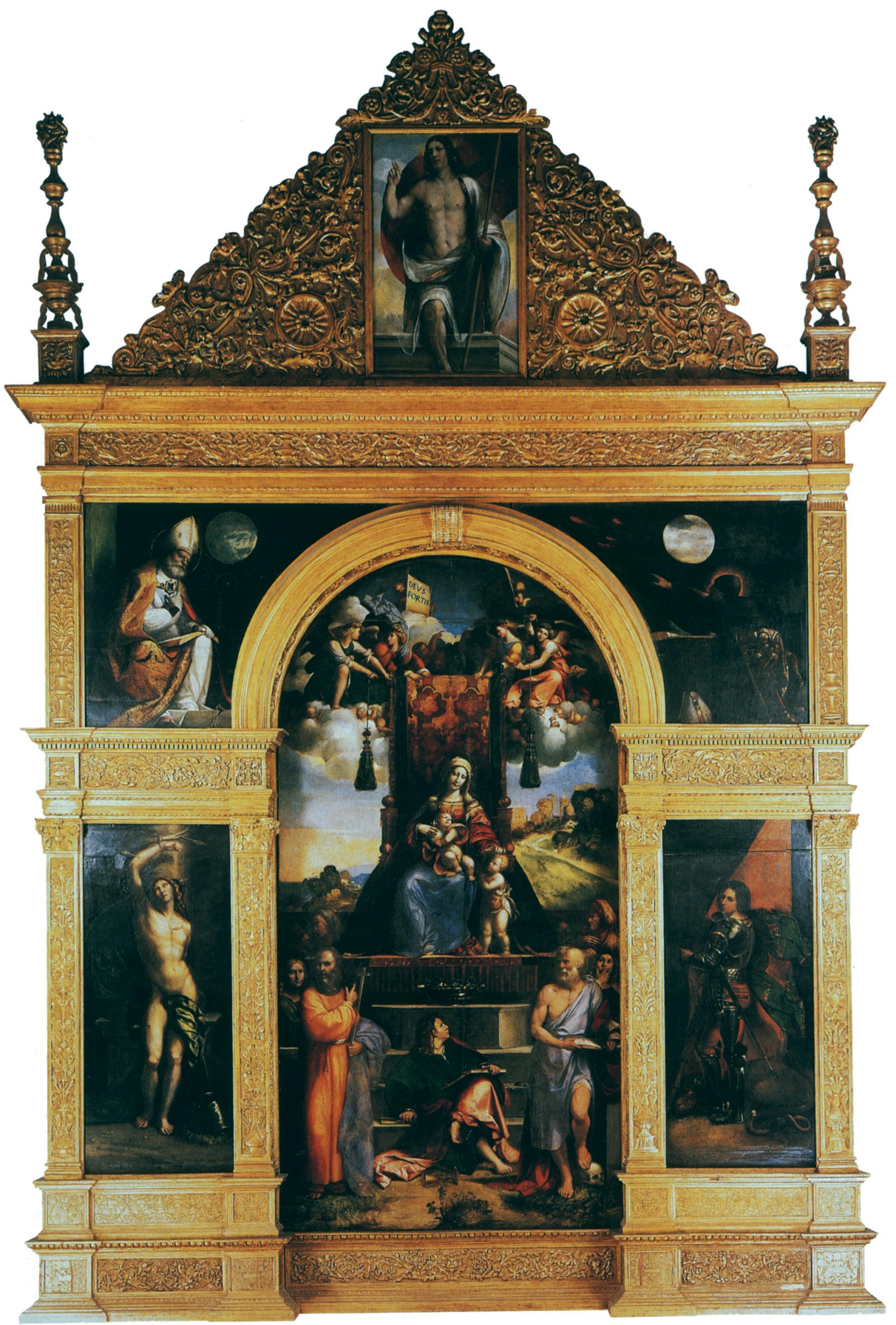

1 Dosso Dossi and Garofalo, Costabili polyptych. Ferrara, Pinacoteca Nazionale (photo: Soprintendenza per i Beni Artistici e Storici, Bologna) 


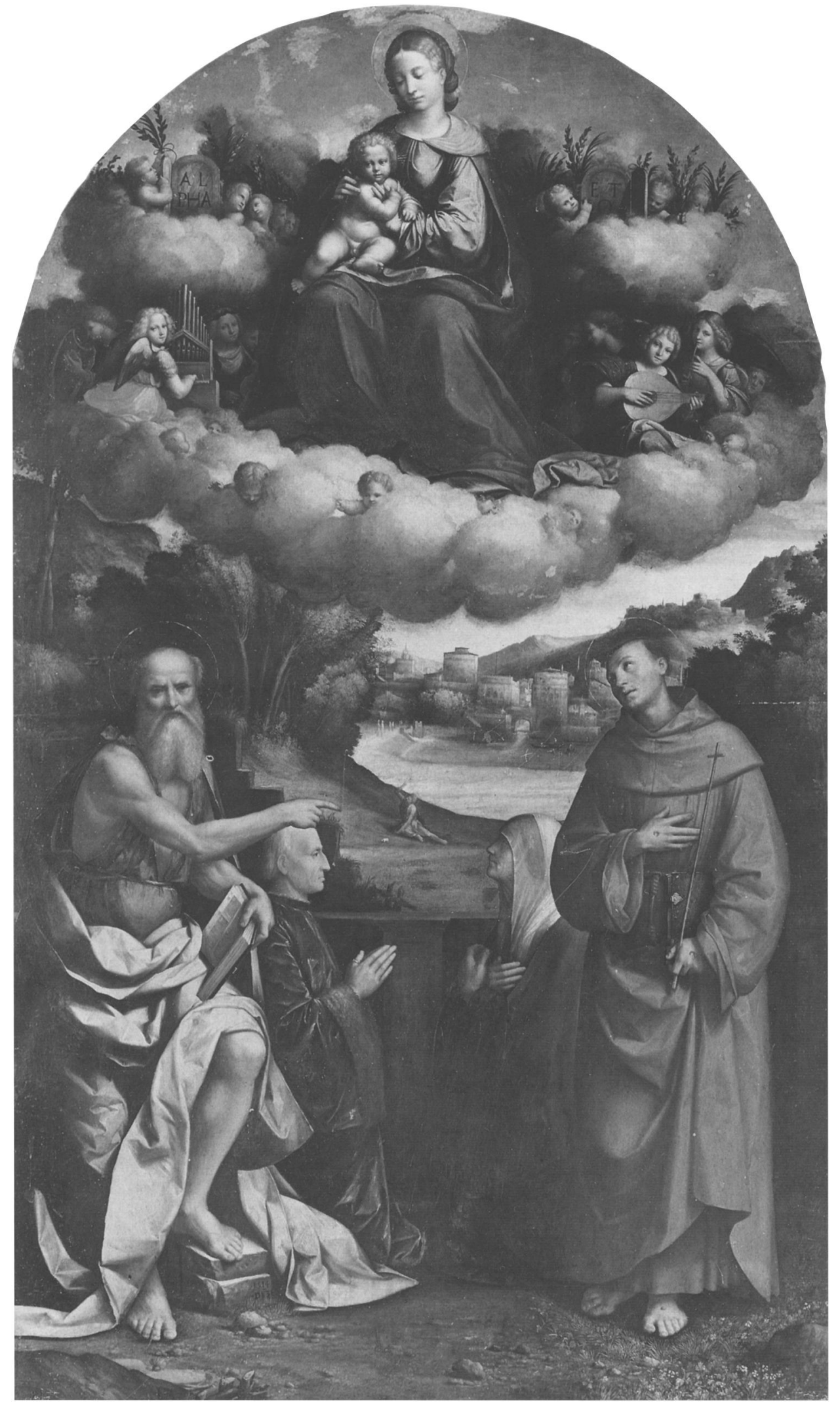

2 Garofalo, Suxena Altarpiece. Ferrara, Pinacoteca Nazionale (photo:

Soprintendenza BAS, Bologna) attention. In the pendant panel, Saint Ambrose sits in contemplation with one hand at his breast and a manuscript resting on his lap. The oculus windows depicted in each of their two cells illuminate the figures with an otherworldly silvery light. The pediment contains an image of the Risen Christ emerging triumphantly from his tomb, another rare subject for the pinnacle of an altarpiece that deserves closer scrutiny.

\section{The State of the Question}

Very few paintings by Dosso can be securely dated, and it is important to note that the zornale documents anticipate the 
conventional dating of the Costabili polyptych, based on stylistic arguments, by more than ten years. ${ }^{14}$ Previously, Alessandra Pattanaro's important discovery of Costabili's testament, dated July 30, 1527, which mentions the Costabili polyptych as extant, led scholars to all but anchor its date to about 1523-24 and assert that the commission arose in the context of the aging patron's funerary plans. ${ }^{15}$ Alessandro Ballarin, who dismissed Vasari's chronology, compared the monumental portrayal of the saintly body to such works as Dosso's Saint Sebastian Altarpiece (Fig. 3), commissioned in 1518 and installed in 1522 in the cathedral in Modena, and the composition of the central panel to Garofalo's Madonna Enthroned with Saints, painted in 1524 for the high altar of the church of S. Silvestro in Ferrara, and now in the cathedral. ${ }^{16}$ Judgments on the division of labor have more or less followed Roberto Longhi, who attributed to Dosso the panels of Saints George and Augustine, as well as the Risen Christ, the Madonna and Child, the saint sitting on the steps, and those standing to the right of the throne. ${ }^{17}$ Debate has arisen over the artist responsible for executing the panel of Saint Ambrose, yet it appears that Garofalo depicted this figure, along with the angels, John the Baptist, and the saints to the left of the throne in the central panel, as well as the panel of Saint Sebastian. ${ }^{18}$ In their recent reconstruction of Dosso's chronology, Peter Humfrey and Mauro Lucco have endorsed Franceschini's dating of the polyptych's completion to 1514, citing artistic precedents in the works of Titian, Giorgione, and especially Raphael's early Roman works. ${ }^{19}$ Despite the lack of documentary evidence, the authors suggested that Dosso himself had visited Rome prior to working on the polyptych, and Humfrey even entertained the idea that Dosso had already begun painting the altarpiece by late $1512 .{ }^{20}$ However, in response to the reopened question of date, Andrea de Marchi and Luisa Ciammitti, among others, have deemed the altarpiece an unorthodox collaboration resulting from two distinct campaigns, with Dosso extensively repainting and "transforming" Garofalo's passages some years after 151314. ${ }^{21}$ The impetus behind this evaluation comes from the detailed photography complemented by an examination report on the Costabili polyptych published by Vincenzo Gheroldi. ${ }^{22}$ The photographs show very impressionistic brushstrokes over more tightly controlled areas of modeling and detail, which are most prominent in the highlights for the hair of the angels and spiritelli in the central panel (Fig. 4), and on the face and robe (especially the knee) of Saint Ambrose (Fig. 5). These "gestures of sprezzatura" are attributed to the hand of Dosso, who presumably, after a period of interruption, completed his panels and altered the work of Garofalo in a style that is seen to comply with the pictorial advancements made by Romanino and Parmigianino in the 1520 s.

These observations have already made an impact on the scholarship of Ferrarese painting, but they require qualification because not enough emphasis is placed on the viewpoint of the beholder. If we refrain from a microscopic viewing of the work and instead look at the polyptych in its entirety and consider its original setting, these broad tonal and textural juxtapositions and evocative displays of surface description may be seen as sophisticated technical solutions for achieving balanced perspective and proper foreshortening. Because the

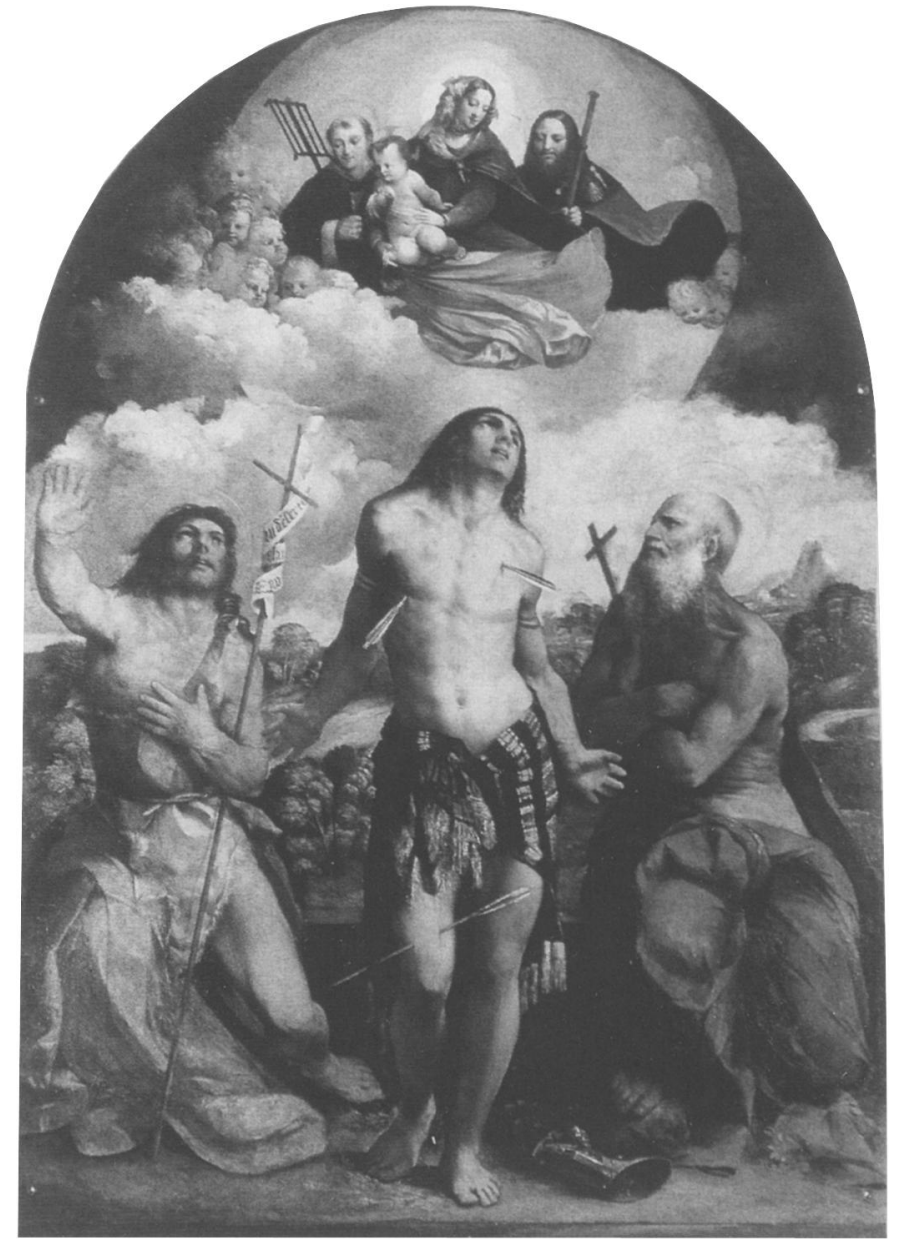

3 Dosso Dossi, Madonna and Child in Glory with Saints John the Baptist, Sebastian, and Jerome. Modena, Duomo (photo: Anderson, Florence)

Costabili polyptych is so immense and would have been viewed at a considerable distance, it posed a formidable optical and artistic challenge. Without these exaggerated and somewhat untamed gestures in the highlights, which resemble the bold and dazzling manipulation of paint exhibited by Titian's late paintings, the entire perspective of the altarpiece (based on an implied light source coming from the right) would collapse and the work would be visually incoherent. Perspective, as Erwin Panofsky teaches us, privileges the viewer, enabling the readability and experience of the image as composition and "symbolic form." ${ }^{23}$ Admittedly, Dosso's vocabulary is innovative and dramatic, especially regarding the punctuation of chiaroscuro and exuberant touches of color for the panels of Saints George and Augustine. Yet the assumption that Dosso painted over Garofalo's work after a considerable hiatus (especially regarding the splashes of yellow highlight for the hair of the spiritelli and the traces of impasto) in order to "modernize" the polyptych fails to grasp Dosso's working methods and the intention behind such exaggerated brushstrokes. In Dosso's stunning Virgin and Child with Saints George and Michael Archangel (Galleria Estense, Modena) of about 1519, the artist applied the highlights on the wings and hair of the Archangel Michael with modulated strokes of iridescent hues over more finely articulated passages (Fig. 6). The commission for this undated altarpiece, 


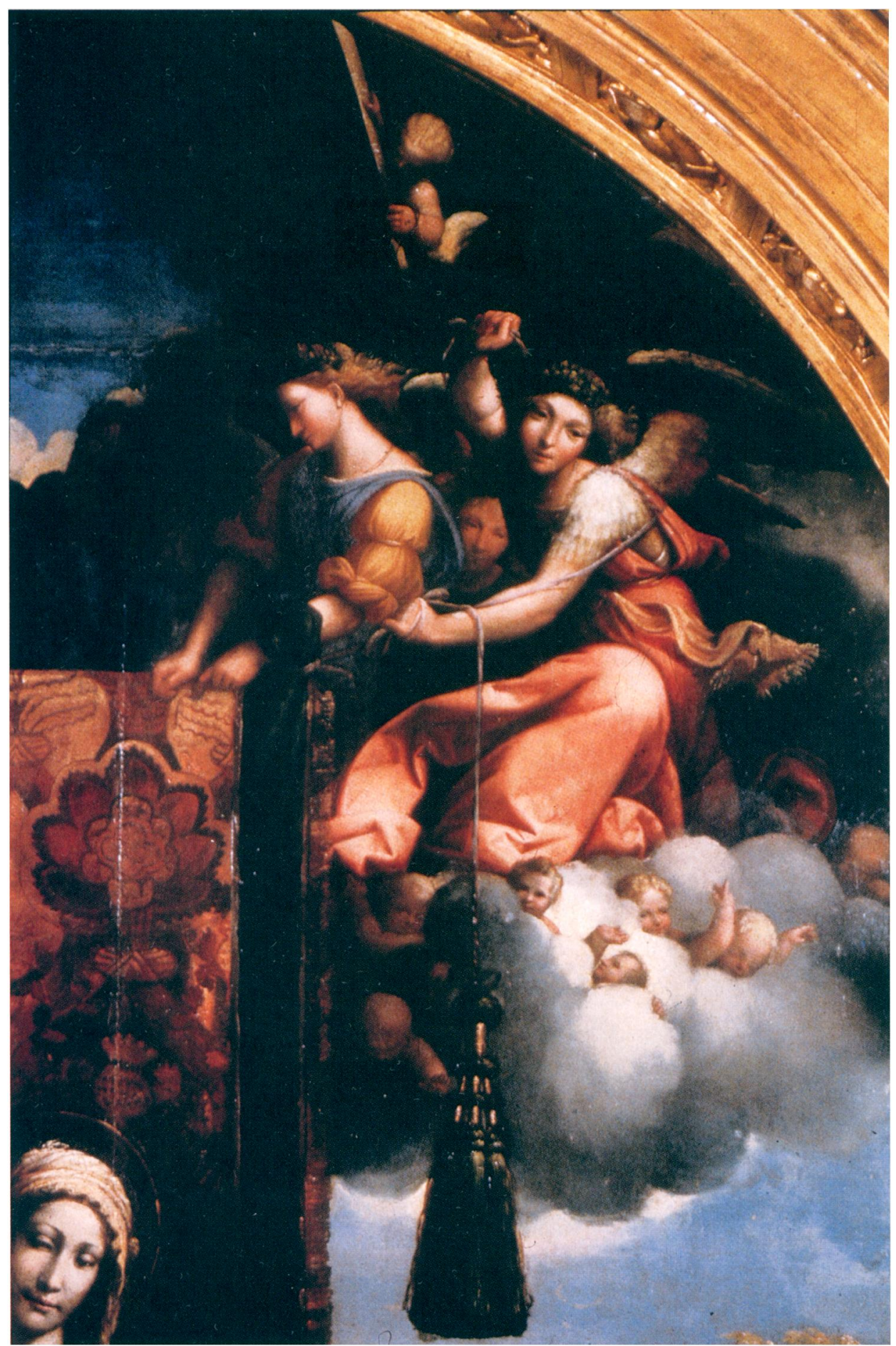

4 Detail of Fig. 1 with angels and spiritelli in central panel which has a provenance from S. Agostino in Modena, was probably awarded to the artist by the Eremitani friars of $S$. Agostino based on their knowledge of Dosso's work for the Ferrarese Eremitani. ${ }^{24}$ The pictorial effect resembles that of the Costabili polyptych, though less exaggerated since the Modenese altarpiece is significantly smaller $(1111 / 2$ by 69 $3 / 4$ inches, or 283 by 177 centimeters). Such overwrought artifice (contemporary to the rest of the composition) was necessary in order to achieve the proper perspective and modeling with the available lighting and the given viewpoint of the beholder.
Alternatively, there is no reason to assume that the highlights and impasto in question are not by Garofalo himself, who could have adjusted his technique according to the visual demands of this monumental work and yet maintained a coherency with Dosso's manner. We can detect a loosening of the brush in some of Garofalo's other paintings, notably in the drapery and visually resonant landscape of the Suxena Altarpiece. In other words, either artist could have-and, indeed, must have-painted these passages of sprezzatura for the altarpiece to be legible from a distance. No historian prior to the publication of Gheroldi's photographs in 1998 deemed 


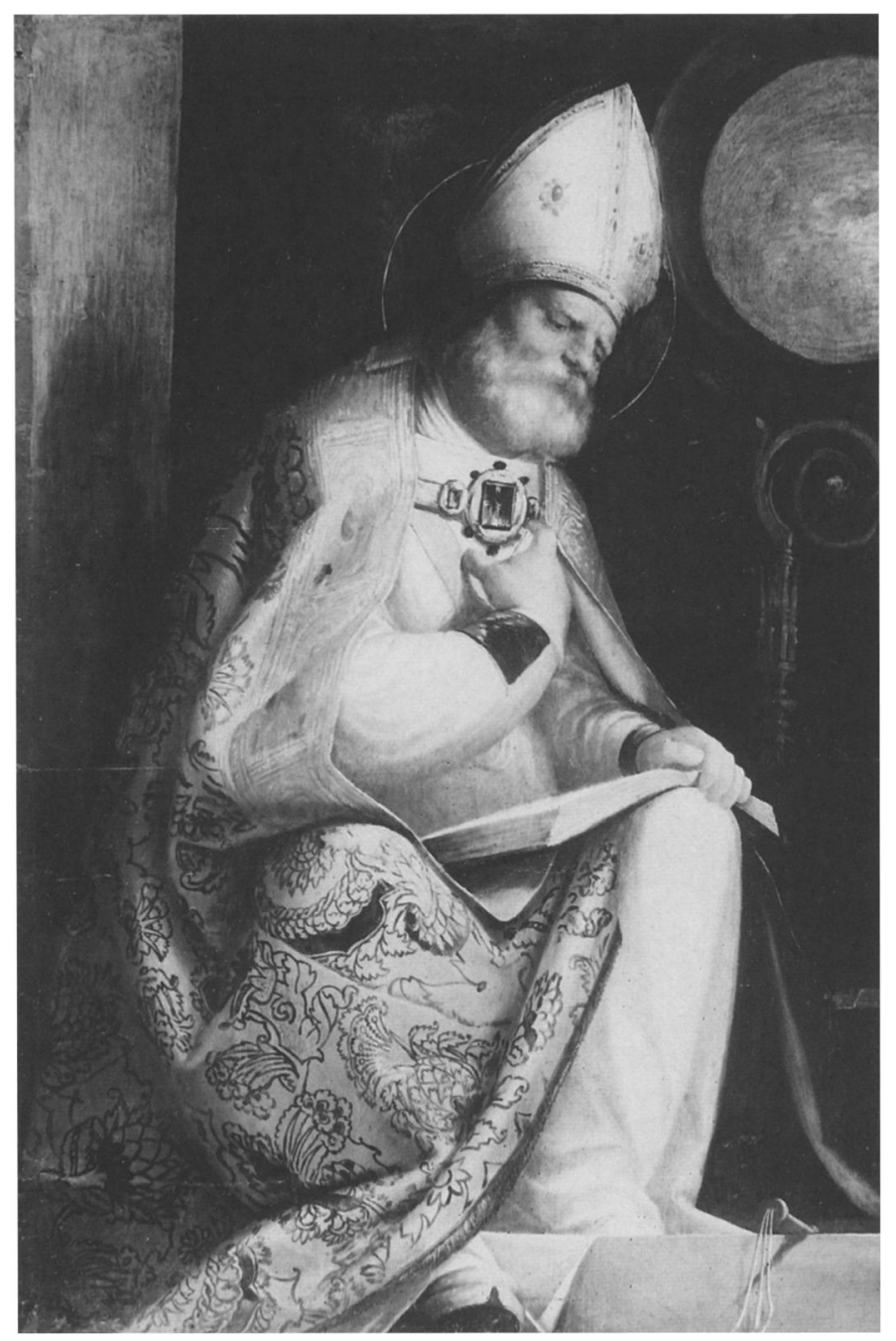

5 Detail of Fig. 1 with Saint Ambrose

the altarpiece as uneven or inconsistent in its execution. ${ }^{25}$ Ironically enough, debate continues over the division of labor and the artist responsible for the design of the central panel. ${ }^{26}$ Furthermore, from a technical point of view, there is no evidence that would impinge on the dating of the Costabili polyptych to 1513-14. Since no cross sections of pigment were taken from the polyptych, Gheroldi could not determine from the numerous infrared reflectographs whether the vigorous brushstrokes were applied contemporaneously or after the paint had dried. ${ }^{27}$ Nor, surprisingly, is there any mention of the evaluation made in 1782 by Cesare Cittadella, who reported that the polyptych had been poorly cleaned and retouched in the areas of shading by imprudent restorers, which may account for certain inconsistencies in the paint layers or the small traces of pigment above areas of crackling. ${ }^{28}$ It is also worth observing that Garofalo imitated the ornamental throne and shape of the grand steps of the Costabili polyptych in his Madonna and Child Enthroned with Saints Lazarus and Job (Pinacoteca Civica, Argenta), which the artist painted for the church of the Madonna della Celletta in Argenta and dated October 21, 1513 (Fig. 7). ${ }^{29}$

As Franceschini himself duly noted, the Costabili polyptych was more than likely completed by 1514 because both Dosso and Garofalo enjoyed subsequent patronage from within the

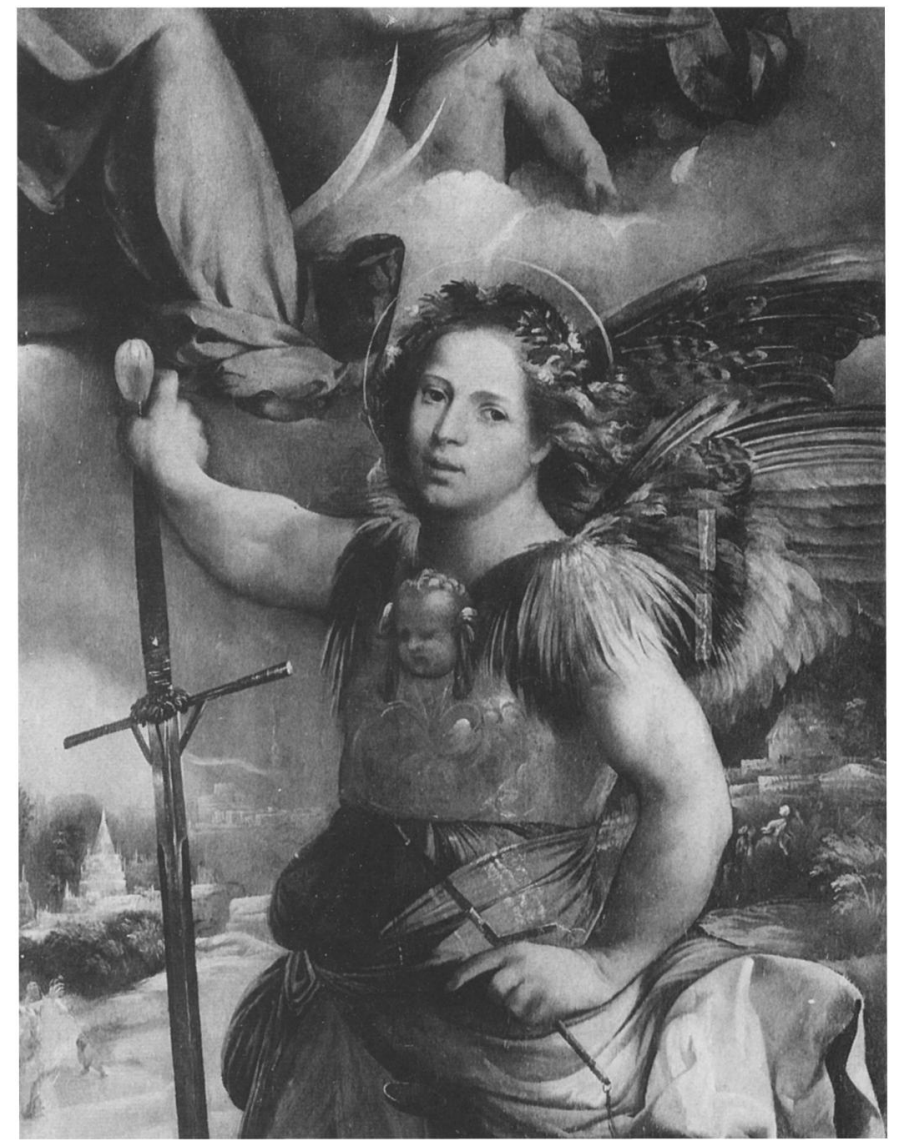

6 Dosso Dossi, Virgin and Child with Saints George and Michael Archangel, detail, Saint Michael Archangel. Modena, Galleria Estense

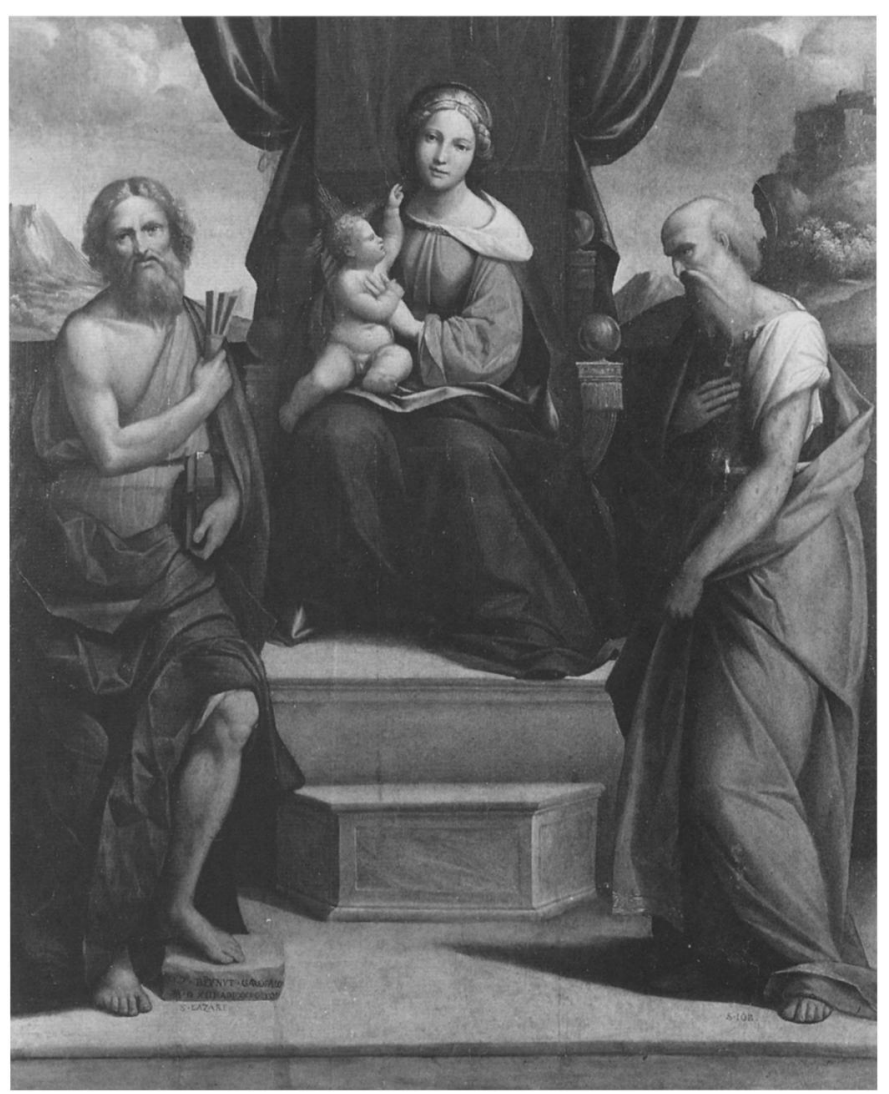

7 Garofalo, Madonna and Child Enthroned with Saints Lazarus and Job. Argenta, Pinacoteca Civica (photo: Soprintendenza BAS, Bologna) 


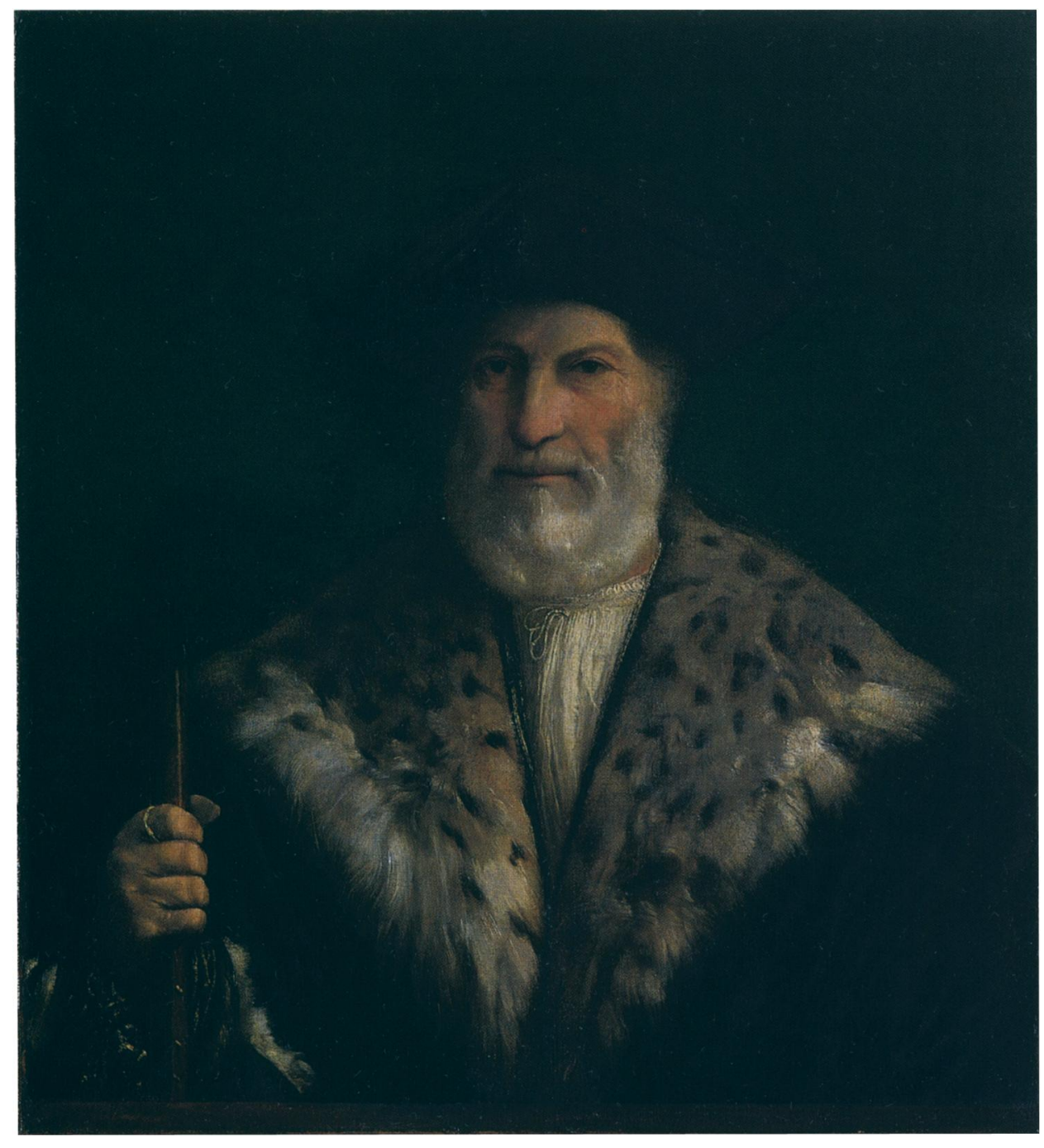

8 Dosso Dossi, Portrait of a Man in a Fur Collar (Antonio Costabili). Milan, private collection (photo: Studio Fotografico Perotti)
Eremitani community and from Antonio Costabili. Would not the patron and the friars first have ensured that the artists satisfied their obligations for what Francesco Scannelli judged to be one of the greatest accomplishments of Emilian art before allocating or overseeing other commissions of the artists? ${ }^{30}$ Documents record that by September 1517, Garofalo had completed his Saint William Altarpiece (National Gallery, London), for which he received his final payments from the Franciscan sisters of S. Guglielmo in Ferrara only after Costabili intervened on the artist's behalf. ${ }^{31}$ There is evidence that Costabili also intervened in a compensatory dispute between Garofalo and the Eremitani regarding the artist's fresco of the Allegory of the Crucifixion (1523), executed for the refectory of S. Andrea (Pinacoteca Nazionale, Ferrara). ${ }^{32}$ New documents reveal, furthermore, that Garofalo, together with the painter Tommaso da Carpi, decorated a chapel dedicated to the Crucifixion and the Madonna in S. Andrea in $1524 .{ }^{33}$ More important, the 1513 zornale documents for the Costabili polyptych, in which Dosso is called "Dosso dalla Mirandola," provide the earliest record of the artist's residency in Ferrara. ${ }^{34}$ The discovery of these documents strengthens the notion that Costabili, a shrewd patron of the arts, was responsible for seeking out the artist for what was possibly his first commission in Ferrara, and whose success helped earn him Este patronage: Dosso is recorded on the Este account books as early as March $1514 .{ }^{35}$ Costabili's confidence in Dosso's artistic abilities apparently extended to the commission of the patron's portrait (ca. 1519-20), now in a private collection in Milan (Fig. 8).$^{36}$ This superb portrait captures the patron's cultivation of his nobility and leadership-a self-presentation aimed at a Ferrarese audience. Just as the physiognomy of the portrait bears the distinctive stylistics of Dosso's artifice, so too do the theatrics of light and shadow the rich colors, and the expressive movements and passions of the human figure in the Costabili polyptych betoken a Ferrarese style, developed through a study of nature and models of artistic excellence.

More is at stake concerning the 1513 commission for the Costabili polyptych than the reconstruction of a stylistic chronology for both Dosso and Garofalo and defining their artistic sources. The debate involves radically different and incompatible interpretations of this image in relation to its religious, civic, and historical context if one dates the work to the mid-1520s as opposed to 1513-14. Thus, the state of the question on the Costabili polypytch is really one of methodological inquiry. There has yet to be a focused or convincing attempt to consider why two artists working in Ferrara in the early sixteenth century would have adopted such a striking 
pictorial vocabulary. What are the cultural function and rhetorical effect of their artistic performance? Moreover, what would a clerical or lay audience expect from the high altarpiece of S. Andrea in 1513 as opposed to the mid-1520s? Among these unresolved questions lies a certainty: the zornale documents clearly state that work on the Costabili polyptych was initiated in 1513, meaning that the carpentry was already designed and an iconography already designated. Even though the painters' discovery of visible forms through which to express the message of the polyptych is itself a process of invention, their figures and stylistic devices must have enhanced the subject matter that was negotiated beforehand and dictated to them by the patron and, as we shall see, the friars of S. Andrea. Significantly, the technical evidence does not reveal any trace of alterations to the subject matter. Another point to consider is that the patron's family chapel, dedicated to the Virgin and dating back to the fourteenth century, had no explicit funerary function prior to $1527 .{ }^{37}$ This calls into question previous assumptions about the motivation underlying the patron's commission. Surely Costabili envisioned his polyptych as a lavish gift to the friars in the hopes of securing future burial rights at the high altar for himself, his descendants, and the remains of his ancestors, who were buried in other churches throughout the city, as his testament specifies. ${ }^{38}$ On the other hand, the unprecedented inscriptions from the Book of Isaiah, the prominent figure of the Risen Christ in the pediment, and the singular appearance of Saint Augustine are testimonies to other initiatives and interests that an explanation of the work solely in terms of a sepulchral function would not allow us to specify. Therefore, any investigation into the altarpiece's meaning must come to grips with the historical circumstances surrounding its commission: this would be Ferrara's involvement in the Cambrai Wars.

\section{Duke Alfonso I d'Este, Antonio Costabili, and the Cambrai Wars}

On April 19, 1509, Pope Julius II made Alfonso I d'Este (1476-1534, duke from 1505) gonfaloniere della Chiesa (defender of the papal standard), enlisting him in the AntiVenetian League of Cambrai (created December 10, 1508) along with the French king and the Holy Roman emperor. ${ }^{39}$ The League of Cambrai aimed to curtail Venice's aggressive territorial expansion and monopolization of the trade routes of the Adriatic Sea. The duke of Ferrara played a pivotal role in the resulting war against Venice; his decisive victory over the Republic of Venice's naval forces at the Battle of Polesella on December 22, 1509, compelled the latter to sign a peace agreement in February 1510 favorable to Julius II. ${ }^{40}$ For all Alfonso's military efforts in the service of the papacy, the duke irritated the pope by consolidating his alliance with the French, who had been a perennial threat to the balance of power in Italy since their capture of Milan in 1499. Julius II also litigated with Alfonso over a license to produce salt in the Papal States, sending his ambassador to deal specifically with Antonio Costabili, a long-trusted diplomat of the Este. Furthermore, notwithstanding the Venetian surrender, Alfonso continued his attacks on the Republic of Venice in order to secure his patrimony in the Polesine that he had recently regained. Infuriated by Alfonso's actions, the pope turned against him by forming an alliance with the Venetians, and with an appeal to Divine Providence announced to an envoy of the republic that "it is the will of God to punish the duke of Ferrara and liberate Italy from the hands of the French." 41 On August 9, 1510, the pope stripped Alfonso of his title of gonfaloniere and published a bull of excommunication against him. On September 14, 1510, Julius II placed the entire city of Ferrara, a traditionally papal territory where the Este served as vicars, under interdict, thus seeking to demoralize Ferrara's civic life and turn the citizenry against its leader. ${ }^{42}$

According to the Ferrarese chronicler Paolo di Tommaso Zerbinati, director of the ducal mint, the interdict of Ferrara stunned the citizens and threatened to turn Ferrara into a religious wasteland: no daily masses were held, many other religious offices were suspended, and most of the priests and monks fled the city. ${ }^{43}$ Worse still, Julius II was relentless in his attack on Ferrara and the Este dominions, conquering Modena (August 18, 1510) and Reggio (July 4, 1512), two important ducal states. Nonetheless, Alfonso successfully defended the city of Ferrara, and his brilliant military skills enabled the Ferrarese, with the aid of the French, to destroy the papal alliance at the famous Battle of Ravenna fought on Easter Sunday, 1512. The war slowly took its toll on Julius II, and toward the end of that year the pope's health declined sharply. Consequently, in what must have been seen as a miracle to the Ferrarese after enduring years of ecclesiastical censure and military oppression, on the night of February 20-21, 1513, Julius II died. With the election of the new Medici pope, Leo X, an armistice was declared, made official by a papal bull published on March 13, 1513, that annulled Ferrara's interdict and readmitted Alfonso to the Church. ${ }^{44}$

Immediately following the peace agreement, Ferrara accelerated its campaign designed to reconstruct its fortifications and repair damages to its religious and civic monuments. Antonio Costabili, Ferrara's chief magistrate, was in charge of this crucial project. ${ }^{45}$ Costabili, who was elected giudice of the Dodici Savi on April 18, 1506, also served as the private counselor (consigliere secreto) to the duke of Ferrara. ${ }^{46}$ During the war he assumed the position of acting duke (vice duca) and played an instrumental role in maintaining security within the city and upholding the spirits of the Ferrarese citizens while Alfonso commanded his troops on the battlefield. ${ }^{47}$ At the conclusion of the conflict, the giudice even held a quasiofficial celebration of Ferrara's independence by throwing a lavish banquet at his private residence attended by the most illustrious personalities in Ferrara. ${ }^{48}$ In recognition of Costabili's role as communal spokesperson and his postwar civic efforts, Daniele Fini, the poet and chancellor of the University of Ferrara, labeled him "pater patriae." 49 A look at the zornale of the Commune for the year 1513 reveals the impressive monetary scope of Costabili's rebuilding initiative. Notably, it is among these records that Costabili's compensation to Dosso and Garofalo appears. Although these payments do not fall under the rubric of "war expense [spesa della guerra]" in the zornale, the chronology suggests that Costabili conceived his polyptych within the context of the war and the campaign following its resolution. Since the court society of Ferrara witnessed a considerable overlap of personal and official interests, it is tempting to see the Costabili polyptych as 
strategically designed to address the entire Ferrarese community-the clergy, the court, and its subjects. ${ }^{50}$

\section{Hypothesis of "Just War"}

Support for interpreting the Costabili polyptych as a civicoriented monument comes from the displayed folios quoting Isaiah 9:6 in its central panel. The Book of Isaiah opens with a vision of Israel in the throes of sin and corruption, where civil unrest has turned to open violence and insolence rules. In the ninth chapter, the prophet names God as the bearer of justice, vindicating the afflictions suffered by Israel at the hands of ruthless kings who have waged war against its cities. God's purpose unfolds as Isaiah foretells the deliverance of Jerusalem from years of war and oppression with the birth of a promised child, whose kingdom of peace shall flourish forever:

For a child is born to us, and a son is given to us, and the government is upon his shoulder: and his name shall be called, Wonderful, Counselor, God the Mighty [Deus fortis], the Father of the world to come, the Prince of Peace [Princeps pacis].

Peace establishes God's covenant with Jerusalem and inaugurates an ideal of justice and righteousness in the context of war. ${ }^{51}$ Peace is synonymous with strength, with victory, with completion. God puts an end to warfare, political oppression, and social injustice in both the spiritual and political senses; thus, these verses from the Book of Isaiah carry strong implications for the duchy of Ferrara and its rulers.

The interpretative schemata governing the Costabili polyptych, as we shall see, incorporate a specific set of religious and civic ideas designed to cast Ferrara's fight against the pope as a "just war." The thesis and policy of "just war" reached the level of articulate debate in the fifteenth and early sixteenth centuries, notably with Lorenzo Valla and Erasmus of Rotterdam, who challenged a long tradition of ecclesiastical reliance on arms to preserve the jus of Christianity. It was Saint Augustine who developed the Christian doctrine of "just war" (bellum justum), which was later elaborated into theory by such theologians as Isidore of Seville and Thomas Aquinas. ${ }^{52}$ By definition, a "just war" meets one or more of the following criteria: it avenges injuries inflicted on a community or recuperates lost possessions; it maintains peace, especially in defense against hostilities; it is commanded by the authority of a prince, or by God. With regard to this humanist discourse, a sense of the altarpiece's meaning and impact, and a context for certain artistic choices, are obtainable if one places it in relation to the devotional requirements of an audience who yearned for God's favor and protection during the war. ${ }^{53}$ Contemporary responses toward the war reveal the close social, political, and religious nexus that sustained the court and the city. In particular, the writings of Andrea Baura and Antonio Meli, two Augustinian friars from S. Andrea, provided new ways of interpreting the evangelical message in order to overcome Ferrara's historical and spiritual conflictspresent and future. Image and text substantiate one another and promise salvation. Accordingly, my focus on questions of meaning and audience intends to reevaluate the pictorial language of the altarpiece in terms of these broader cultural tendencies.

\section{Humanist Responses to War}

Faced with papal oppression and spiritual censure, the Ferrarese community stood poised between ecclesiastical obedience and patriotic loyalty, meditating on God's providential mastery over history. The accomplished yet little-known poet and courtier Francesco Bovio (Ferrara, 1472-after 1543) yearned for peace in a number of his writings and sought to reestablish an ideal of justice that is promised in God's covenant with man. ${ }^{54} \mathrm{~A}$ characteristic example appears in an unpublished poem, dated August 1512, addressed to Bovio's friend and spiritual companion named Alexander, a certain Augustinian from the congregation of the Lateran canons, who occupied the church of S. Lazzaro of Ferrara. The context of the poem is Ferrara's struggle (ultimately futile) to defend the city of Rovigo against enemy capture. In his lament over a land swarming with hostile militia, Bovio explains that soldiers generate only ruin, whereas God generates peace; the relevant closing lines read as follows:

This is the way of soldiers, they cannot endure quiet but always love uproar from which they can enrich themselves. We desire peace, God of Peace [pacis Deus], O, make it turn out well, and by your gift restore to us peace which is henceforth stable. You, nourishing God, I pray, foster us with peace of the body and of the spirit, which this world itself cannot supply. ${ }^{55}$

It is clear that the doctrine of peace is here being promoted and deployed within strongly ideological arguments against the war and the maneuverings of Christianity's leader. Even though Julius II proclaimed his war as the will of God, in his quest to consolidate an unbroken chain of Papal States from Rome to the Adriatic Sea, he was ruthlessly killing innocent Christians. It was for this reason that Erasmus of Rotterdam considered the pope the greatest offender against peace, labeling him a barbarian tyrant, a new Caesar, whom the theologian denies access to Heaven in his Dialogus Julius exclusus e coelis, published (anonymously) in $1517 .{ }^{56}$ Bovio's poem participates in humanist discourses on reconciliation by contrasting peace to war in order to plea for the end of hostilities and foster concord. When the poet invokes the God of Peace (pacis Deus) he is assimilating a traditional prophetic language calling for the defeat of wickedness and the fulfillment of God's covenant with man.

A parallel development of scriptural themes occurs in the Costabili polyptych with the strong visual presence of the same prophecy by Isaiah. The Book of Isaiah proclaims God as the bearer of justice, the vindicator. The replacement of war with peace that is manifest in the birth of a promised child orchestrates Israel's participation in its own redemption. ${ }^{57}$ Clearly, the quotation of Isaiah 9:6 in the Costabili polyptych is uniquely determined by Ferrara's historical situation and responds to the emotional climate of the community. But if we claim that Ferrara envisioned its war against the pope as historically and conceptually a reenactment of the trials and joys experienced by the biblical nation of Israel, then we need to examine more closely how the Word of God was read, meditated on, and experienced in Ferrara. It is helpful to examine divergent readings of Scripture in relation to historical crisis. 
Consider, for example, Erasmus's Querela Pacis (A Complaint of Peace), written in 1516 (published in 1517) while he was the counselor to Prince Charles of Burgundy (later Charles V). The theologian dedicated his work to Philip of Burgundy, bishop of Utrecht, urging reconciliation between France and the Holy Roman Empire. Erasmus, who centers his discourse on Christ, advocated peace as a powerful political weapon. By means of rhetorical argumentation, Erasmus develops his discourse using Isaiah 9:6 as his primary topos. ${ }^{58}$ In the Querela Pacis, the interlocutor Peace pointedly argues the following:

Survey the life of Christ from start to finish, and what else is it but a lesson in concord and mutual love? What do all his commandments and parables teach if not peace and love for one another? Think of the mighty prophet Isaiah: when he was inspired by the divine spirit and prophesized that Christ would come to unite the world, did he promise a tyrant, a sacker of cities, a warrior, a conqueror? He did not. What then did he promise? A Prince of Peace. Isaiah wished it to be understood that his Prince was the best of all princes, and so he named him after that quality which he judged to be best. ${ }^{59}$

The Book of Isaiah figures prominently in Erasmus's politics of nonviolence. Because Erasmus saw no grounds for war, he interpreted the references to battles in the Hebrew Bible allegorically. War, according to the theologian, meant a battle against vices, personal and spiritual. The conquest of vices is the source of peace.

\section{Friar Andrea Baura on God's Strength}

Significantly, the Costabili polyptych invokes the same topos of Isaiah, indicating that the Ferrarese had a considerable investment in the discursiveness of the image. The method underlying the altarpiece's inventio, literally, the "discovery" of an argument, as Leon Battista Alberti defines it in his De pictura of $1435,{ }^{60}$ follows the same rhetorical principles governing the humanist theology that was cultivated by the Eremitani friars of S. Andrea. The friars came to S. Andrea in the mid-thirteenth century and subsequently enjoyed the patronage and benefices of the Este and the leading families of the community, especially the Costabili. The Augustinians established an important theological center at S. Andrea, which gained accreditation in $1406 .{ }^{61}$ At the time of Ferrara's conflict Andrea Baura (born ca. 1482-83), an Augustinian from S. Andrea, composed an exegetical work entitled Exposition ingeniosa et accomodata a nostri tempi del XIV, XV, et XVII Psalmo ${ }^{62}$ Baura published his exposition in Ferrara on February 11, 1513, and dedicated it to Lucrezia Borgia, the duchess of Ferrara, who had come to S. Andrea for spiritual solace while her husband was on the battlefield. The friar's exegesis weds medieval commentary to a humanist approach to the Scriptures through his reassertion of the absolute primacy of the biblical texts. That Baura chose the vernacular to write his exposition, which aimed at the comprehension and content of a particular passage or sentence from the Vulgate, is a gesture toward a civic-oriented Christianity. Baura's theology, in contrast to Erasmus's political agenda, promotes a policy of "just war."63 A highly relevant example illustrating this process is Baura's exposition on Psalm 17:2, "Diligam te Domine fortitudo mea" (I will love thee, O Lord, my strength), which concerns King David's thanks to God for victory in battle and deliverance from persecution by the tyrant Saul. Baura labels David a figure of the Church Militant (chiesa militante), interpreting these passages as the need for faith to ensure victory and purify the Church. Peace comes through God's strength, which in turn nourishes King David's soul:

Diligam te domine: O Lord I continue to think about what I must do so as not to be ungrateful to your majesty, which is of such grace that you conceded to liberate me from so many calamities. Yet I do not know what works for me because all of my deeds are nothing in front of your infinite majesty; I know that you do not need my deeds. . . . Fortitudo mea: This is my strength through which I will save myself if ever I were tormented by my enemies. And if you are my strength, who will there be with the presumption to offend me by any means? Other times when I was not loving you I put my confidence in earthly defenses, in weapons, in soldiers, in strong walls, and in fortifications, which appeared impregnable; but I was deceiving myself, because there is no strength where you are not. ${ }^{64}$

Additional references to the fallen pagan cities of Rome and Carthage invite both a literal and metaphoric (or spiritual) reading of Scripture, exploring the full semantic dimensions of the biblical text under inquiry. Baura's exegesis of David's thanksgiving for military victory must be read against the Book of Isaiah because Isaiah's prophecy is filled with references to Davidic monarchy. In their different ways, Isaiah 9:6 and Psalm 17 both evoke the themes of peace through strength and divine intervention, and would therefore legitimate the use of arms with recourse to Divine Providence.

The invention of the Costabili polyptych correlates with the philological interpretation of Scripture practiced by Andrea Baura, whose profoundly humanist method historicizes the biblical text. ${ }^{65}$ The reading habits of the Augustinians at $\mathrm{S}$. Andrea suggest that Psalm 17 functioned as a subtext informing the interpretative schemata of the Costabili polyptych. In turn, this could indicate that Andrea Baura participated in devising the invention of the altarpiece, a point to which I shall return.

That the inscriptions pronounce a divinely ordained victory is corroborated by the overall format of the polyptych. The magnificent frame with its impressive central arch may have been designed to evoke triumph. ${ }^{66}$ In a related argument, Deborah Howard has suggested that Titian's The Assumption of the Virgin (ca. 1515-18), painted immediately following the Cambrai Wars for the high altar of the S. Maria Gloriosa dei Frari in Venice, carries implicit political connotations of Venetian victory through its triumphal arch-like frame and coronation imagery (Fig. 9) ${ }^{67}$ The "ecstatic tone" of Titian's altarpiece, which is notably flanked by tombs of the doges, shows a "radiant" and "victorious" Mary that Howard describes as "tinged with patriotic allegory." 68 An equally powerful image in the Costabili polyptych is the Resurrection of Christ in its gabled pinnacle. In addition to seeing it as a symbol of salvation, we might interpret the image of the Risen 


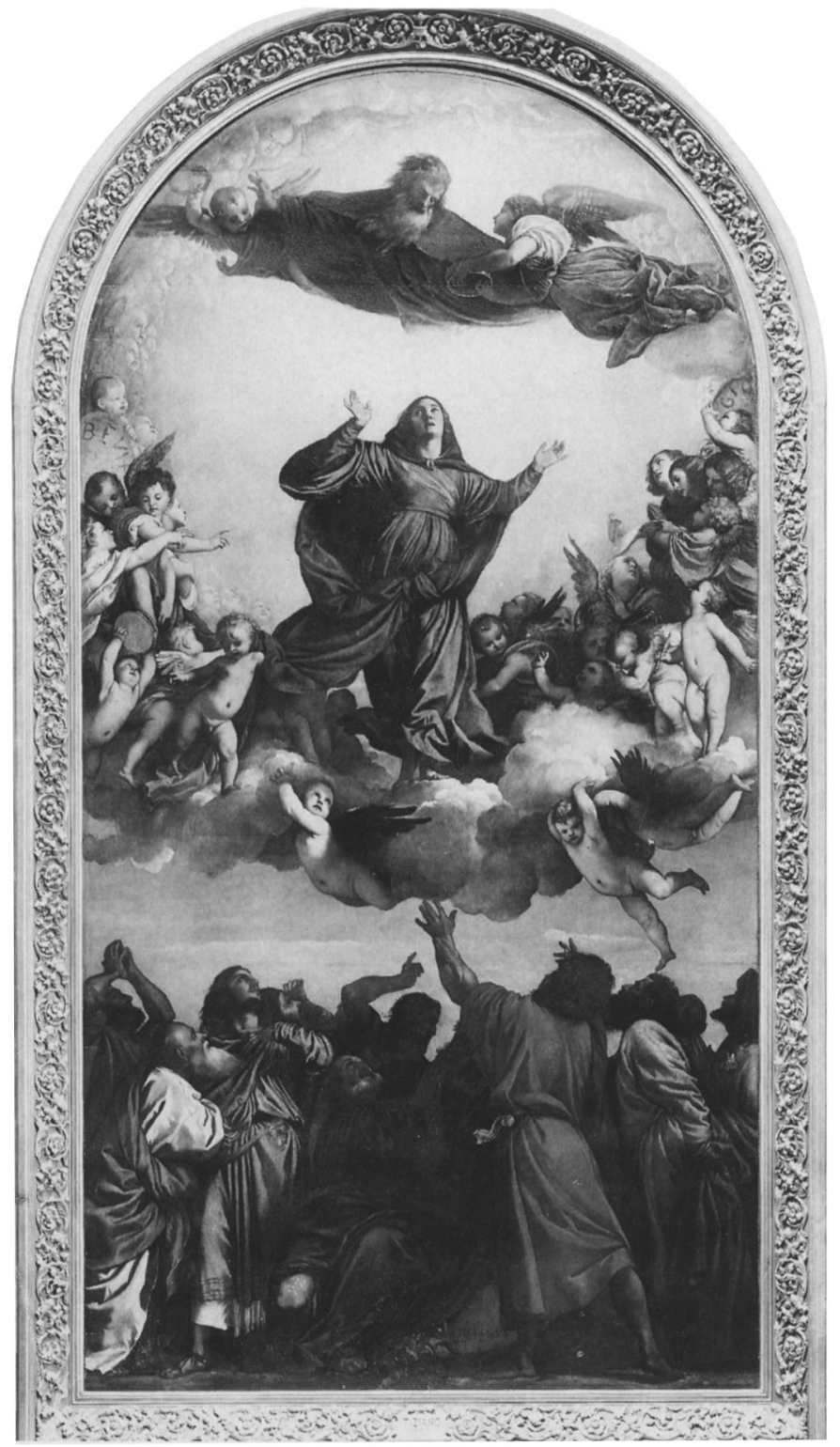

9 Titian, The Assumption of the Virgin. Venice, S. Maria Gloriosa dei Frari (photo: Alinari/Art Resource, New York)

Christ as an allusion to Ferrara's victory at the Battle of Ravenna. ${ }^{69}$ As I noted earlier, a decisive victory for the Ferrarese came on Easter Sunday, April 11, 1512, when Alfonso's forces, armed with his mighty cannons, obliterated Spanish and papal troops in one of the bloodiest confrontations of their conflict. So stirring was the defeat for the papacy that in his inaugural oration for the Fifth Lateran Council sponsored by Julius II in Rome on May 3, 1512, the Augustinian Egidio da Viterbo, prior general of the Eremitani, described the defeat at Ravenna as a sign of "divine displeasure" of the Church's reliance on arms. ${ }^{70}$ Egidio interpreted historical events eschatologically with recourse to Scripture, believing that history yielded an understanding of God and prefigured the fate of the Church. ${ }^{71}$ The Battle of Ravenna represented Ferrara's one true victory, a show of strength. Reading the image of the Resurrection in the Costabili polyptych as a symbol of Ferrarese victory would have thus made all the more immediate the eternal truth of the divine miracle, when Christ conquered death. It is plain that the historical semantic of the prophecy of Isaiah, complemented by forms and themes affirming triumph, serves to cast the city of Ferrara as a new Jerusalem, enjoying God's favor and protection. The altarpiece fosters religion as much as it celebrates the political ambitions of the duchy.

\section{Saints Ambrose and Augustine on "Just War"}

What I have been arguing thus far is that the Costabili polyptych is a highly allusive work that creates layers of meaning through its close engagement with the biblical text and exegetical traditions. The selection and arrangement of saints, far from being eclectic or arbitrary, contribute to the complexity of meaning. With regard to the representation of Saint Jerome, Renaissance humanists considered the saint the "Christian Cicero"; philological investigation so dominated his life that he became the personification of biblical scholarship. ${ }^{72}$ Accordingly, the emphasis on books, intellectual pursuits, and meditation is meant to sustain a theological discourse in a move from verbal to visual exegesis. The experience of a work of art for the visually literate Ferrarese audience becomes a discursive exercise, requiring a variety of interpretative techniques. ${ }^{73}$ On a certain level of reception, therefore, the strategic pairing of Saints Ambrose and Augustine directly flanking the citations from Isaiah would serve to deepen the question of the legitimate use of arms to preserve a Christian state.

In a number of his writings Saint Ambrose sets out a political theology with the promise of military victory in return for doctrinal obedience. A notable example is his funeral oration for Emperor Theodosius of 395 (De obitu Theodosii), which was composed when barbarian invaders threatened the fate of the Roman Empire turned Christian state. Ambrose champions Theodosius as the exemplary Christian ruler, the guardian of the Church, distinguished by his piety and zeal. With fervor Ambrose exclaims: "He bore the heavy yoke, since he endured exile because of filial devotion and since he assumed the imperial power when the Roman Empire was overrun by barbarians. He bore the heavy yoke that he might remove tyrants from the Roman Empire. But, because he labored here, he rests [in heaven]." 74 The defense of the Christian state by just means was so vital to the theology of Saint Ambrose that he went so far as to claim that Theodosius "gained the grace of Christ and the loyalty of the army, to which he was a proof that God cherishes devotion and is the avenger of treachery." 75 The whip at Ambrose's feet in the Costabili polyptych is an important iconographic detail that corroborates this theology, symbolizing the saint's defense of orthodoxy in 386 against the Arian and pagan parties; the scourge is also a symbol of the saint's miraculous appearance and protection of the Milanese army against rebels at the Battle of Parabiago on February 21, 1339.

Significantly, Saint Augustine drew from the writings of Ambrose to develop the doctrine of bellum justum, which in the De civitate Dei concerns the expansion of the Roman Empire as divinely ordained. Augustine, who calls war "a necessary evil," explains in book 4 how the Romans brought jus to their hostile neighbors: "It was certainly the injustice of those against whom they waged just wars that helped the [Roman] empire to grow, since it would undoubtedly have remained small if peaceful and honest neighbors had never 
10 Silver coin (quarto) of Alfonso I d'Este. London, British Museum (photo: $\odot$ The British Museum, London)
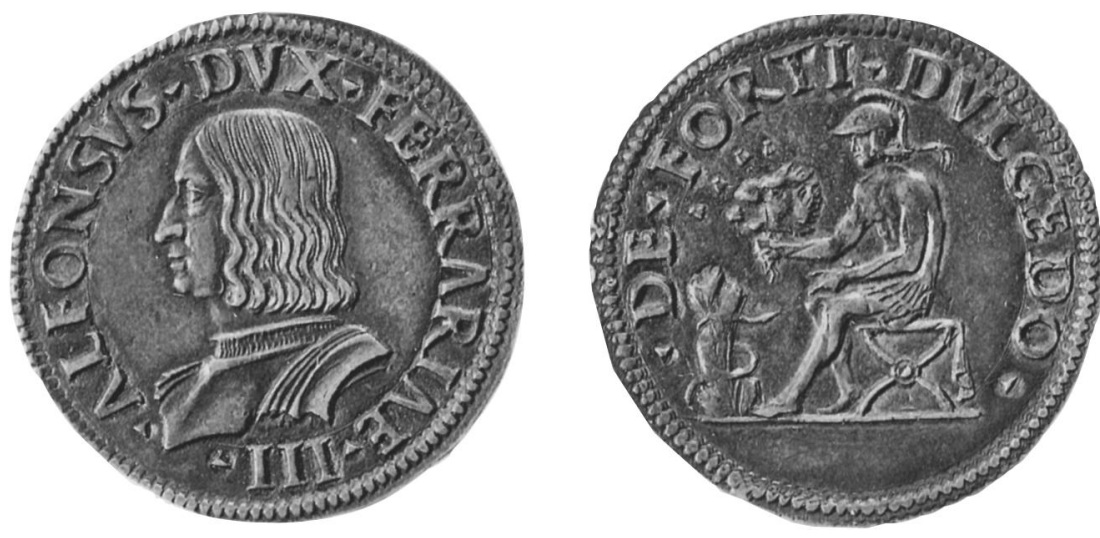

by any wrongdoing given occasion for war."76 Augustine assimilated Roman ideals into Christian theology by basing his doctrine of peace on the precarious concept of pax romana, which rested securely on the idea of military victory. Not everyone embraced Augustine's views, however. Erasmus sharply criticized the theory of bellum justum in his adage "Dulce bellum inexpertis" (first published in 1515 with later additions), on the grounds that Augustine's methods meant a contamination of Scripture with secular Roman tradition. ${ }^{77}$ Erasmus, whose political thoughts are informed in part by the critique of imperial subjugation voiced by Lorenzo Valla (1406-1457), considered war a destruction of God's providence. ${ }^{78}$ War, as a historical reality in early sixteenth-century Europe, meant Christian fighting Christian, and this, according to the theologian, directly conflicted with Mosaic law. Yet the Ferrarese appealed to such biblical warriors as King David, who, as Saint Ambrose remarks in his De officis and De apologia prophetae David, was an exemplum of Christian faith, a servant of God who never engaged in battle unless provoked or by divine command. ${ }^{79}$ The precedent set by David informs a recurring argument in De civitate Dei, in which Augustine condones war insofar as its battles and campaigns contribute to God's end-the punishment of the wicked and the establishment of peace and concord: "For even they who choose warfare desire nothing but victory; it follows that they desire by waging war to arrive at a glorious peace." 80 Furthermore, Augustine mandated that Christians rulers and magistrates must wield their power not only to secure peace but also to promote religion. Thus, the message of peace communicated in Antonio Costabili's altarpiece represents God's covenant with man as much as it represents the cornerstone of a Christian state. While we shall return to the peculiarities posed by the images of Saints Ambrose and Augustine, their very presence flanking the citations from Isaiah serves as testimony in support of "just war."

\section{“Princeps Pacis": Princely Allusions or Divine Intervention in Battle?}

Did Antonio Costabili intend the verse "Princeps pacis" in his altarpiece to celebrate the duke of Ferrara? Certainly Isaiah's prophecy recalls eschatological verses (such as the verse "Rex pacificus" from the poem "In adventu regis") sung during imperial triumphal receptions throughout the Middle Ages and the Renaissance; ${ }^{81}$ indeed, Duke Alfonso I d'Este legitimately raised arms in defense of his homeland in order to secure peace. The appellation "Prince of Peace" might allude to earlier Este ceremonial monuments, namely, the equestrian monument constructed in 1451 and dedicated to the twelfth marquis of Ferrara, Niccolò III d'Este (1383-1441), which once carried the inscription (now lost) on its supporting arch declaring Niccolò thrice creator of peace in Italy (TER PACIS ITALIAAE AUCTORI).$^{82}$ Moreover, the inscriptions from the Hebrew Bible in the Costabili polyptych correspond to Duke Alfonso's self-conscious political identity, whereby he fashioned himself as biblical warrior and model of Christian virtue. For example, a coin minted by the duke in 1505 (Fig. 10) shows his portrait on the obverse, while the reverse bears the inscription "De forti dulcedo," which derives from Judges 14:14: "de forti egressa est dulcedo" (out of the strong came forth sweetness). The figure on the reverse is the biblical hero Samson, who was blessed by God and who in the medal holds the head of a lion he has just slain, from which bees make a hive and produce honey. ${ }^{83}$ The underlying themes from Judges 14:14 and Isaiah 9:6, though developed in different contexts, are intimately related, pronouncing the sweet rewards resulting from God's favor and might.

However, there are no direct allusions to the Este, nor even a donor portrait or Costabili's coat of arms to make overt any honorific intentions. Alternatively, there seems to be an emphatic address to God in his role as the almighty Prince of Peace as well as the theme of divine intervention. The Christ Child holds his orb of dominion while resting lovingly in the lap of the Virgin, who is seated triumphant directly under the prophetic inscriptions. The regalia adorning the Madonna and Child in the central panel are quasitheatrical; the triumphal arch, opulent tapestry, hanging decorative tassels, and offering of a silver bowl teeming with fragrant fruits on the steps invite a comparison with well-documented ceremonial entries, spettacoli, and sacre rappresentazioni held in Ferrara and throughout Italy. ${ }^{84}$ Although the Madonna's majestic throne and the assembly of saints relate to the sacre conversazioni of such Emilian and Venetian artists as Lorenzo Costa, Giovanni Bellini, and Cima da Conegliano, the fact that the female saints are placed in the background further reflects the spatial parameters defined by sacred spectacles. ${ }^{85}$ These symbolic and ceremonial details of the altarpiece suggest that the Ferrarese celebrated the Madonna's role as merciful intercessor.

A look at the Ferrarese chronicles for the year 1511 casts light on this process. Throughout this year Alfonso I d'Este 


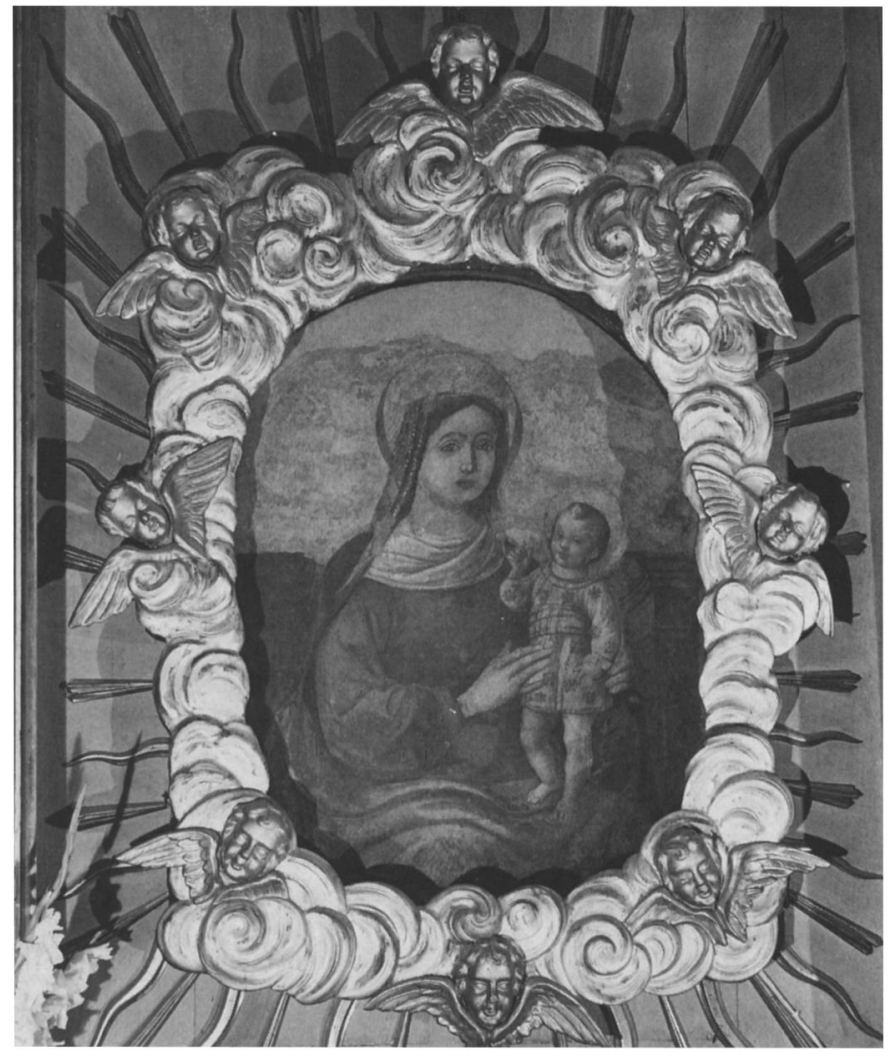

11 Madonna and Child. Ferrara, Madonnina (photo: Musei Civici Arte Antica, Ferrara)

was busy fortifying the defensive walls around the city. Amid the rubble of the demolished bastion at the Porta di Sotto, not far from the church of S. Andrea, a painted image of the Madonna was found intact (Fig. 11). The citizens considered the very survival of the image miraculous. From an enthusiastic report given by the chronicler Zerbinati, we learn that the image had the power to perform miracles, including, significantly, creating an image of the Christ Child:

[1511] In the same month of June Our Lady began to perform miracles in a newly constructed pilaster of stone in the bastion of the Porta di Sotto. There was an image of Our Lady, just her head and face, in this pilaster, which was above the gate and bridge of the aforementioned Porta di Sotto. And when it was destroyed and everything torn down last winter, the very head was not ruined in any way, and having been rediscovered thus intact, it was shown to our duke, and our lord had a pilaster made in the same bastion to place the image inside, and there it began to perform many miracles. Then it happened that the entire figure was completed, seated with her son standing, by a painter who said and claimed that, wishing to make the child and not knowing how to do so, after having returned from lunch, found a whiteness where he had later depicted the child and the head of the child. He showed the whiteness to many people, and proceeded to make the standing little boy in that very place where the whiteness was appearing. Later the image performed infinite miracles for many foreigners, who came to visit that spot, and one began to make a capital above the pilaster and then a bigger one was made so the people could stand under cover; and many people assembled together, both citizens and outsiders. ${ }^{86}$

The Madonna di Porta di Sotto had a profound psychological effect on the city, and it is certain that the duke of Ferrara, by ordering that the image be placed back into the newly fortified bastion, believed the Madonna could protect the city from the pope's wrath. ${ }^{87}$ The intense channeling of public devotion toward the miraculous image generated a series of canzone (largely unpublished) in the Virgin Mary's honor. A compelling example is Francesco Bovio's "Ad illibatam Virginis imaginem ad Portam Inferiorem," dated 1511 (see App. below), in which the poet refers to the Madonna di Porta di Sotto as the city's Magna Parens (Great Mother), beseeching her to end the many months of punishment endured by his community. So great was the belief in the image's miraculous power that in 1512 worshipers established a confraternity named in honor of the Virgin's intercession or "visit" to Ferrara during their conflict: the Società della Visitazione della Porta di Sotto. ${ }^{88}$

The venerated image of the Madonna di Porta di Sotto, Ferrara's Magna Parens, became the focus of civic care at the conclusion of the war. The civic official responsible for finding a permanent home for the miraculous image was Antonio Costabili. On April 8, 1513, Costabili assembled thirty-two high-ranking citizens in his private residence in order to discuss the construction of a church that would house the image that had protected the city. ${ }^{89}$ Ferrarese church historians dispute the date of the completion of the church, called in the vernacular tongue the Madonnina, located near the church of S. Andrea and the palace of Antonio Costabili (Fig. 12). Marc' Antonio Guarini records the construction date as July 24, 1526, whereas Giuseppe Scalabrini lists it as July $24,1531 .^{90}$ In either case, it is clear that Costabili had an intense and, as Isabella Fedozzi has suggested, long-standing devotion to the Virgin..$^{91}$ Costabili's direct involvement with the civic interests of the community regarding the Madonna di Porta di Sotto may have prompted him to celebrate in his own altarpiece the Madonna's role as Ferrara's intercessor. The ostentation displayed toward the Madonna in the Costabili polyptych becomes all the more meaningful when we recall that the patron's chapel was dedicated to the Virgin. Moreover, the church of S. Andrea was consecrated on March 13 (1438), the very same day in 1513 on which a papal bull nullified all spiritual censures in Ferrara. ${ }^{92}$

\section{Saints George and Sebastian}

The prominent status afforded to Saints Sebastian (Fig. 13) and George (Fig. 14) caters to the various expectations of an audience that would have encountered the image immediately following a war. Both saints stand symbolically as soldiers of God and of Ferrara. Dosso stages Saint George in a poised contrapposto as he stands triumphant over the dragon, who exhales his final puffs of smoke. In his study of Cosmè Tura's Roverella Altarpiece (ca. 1479, now dispersed), which included an image of Saint George decorated with Este heraldry, Stephen Campbell has demonstrated the relevance of the story of Saint George as told in the Legenda aurea for establishing the theme of harmony between Church and 
12 Andrea Bolzoni, Pianta di Ferrara, 1800 , detail showing southeast quarter of Ferrara, with S.'Andrea (7), Madonnina (59), and Antonio Costabili's palace (130) (photo: Musei Civici Arte Antica, Ferrara)

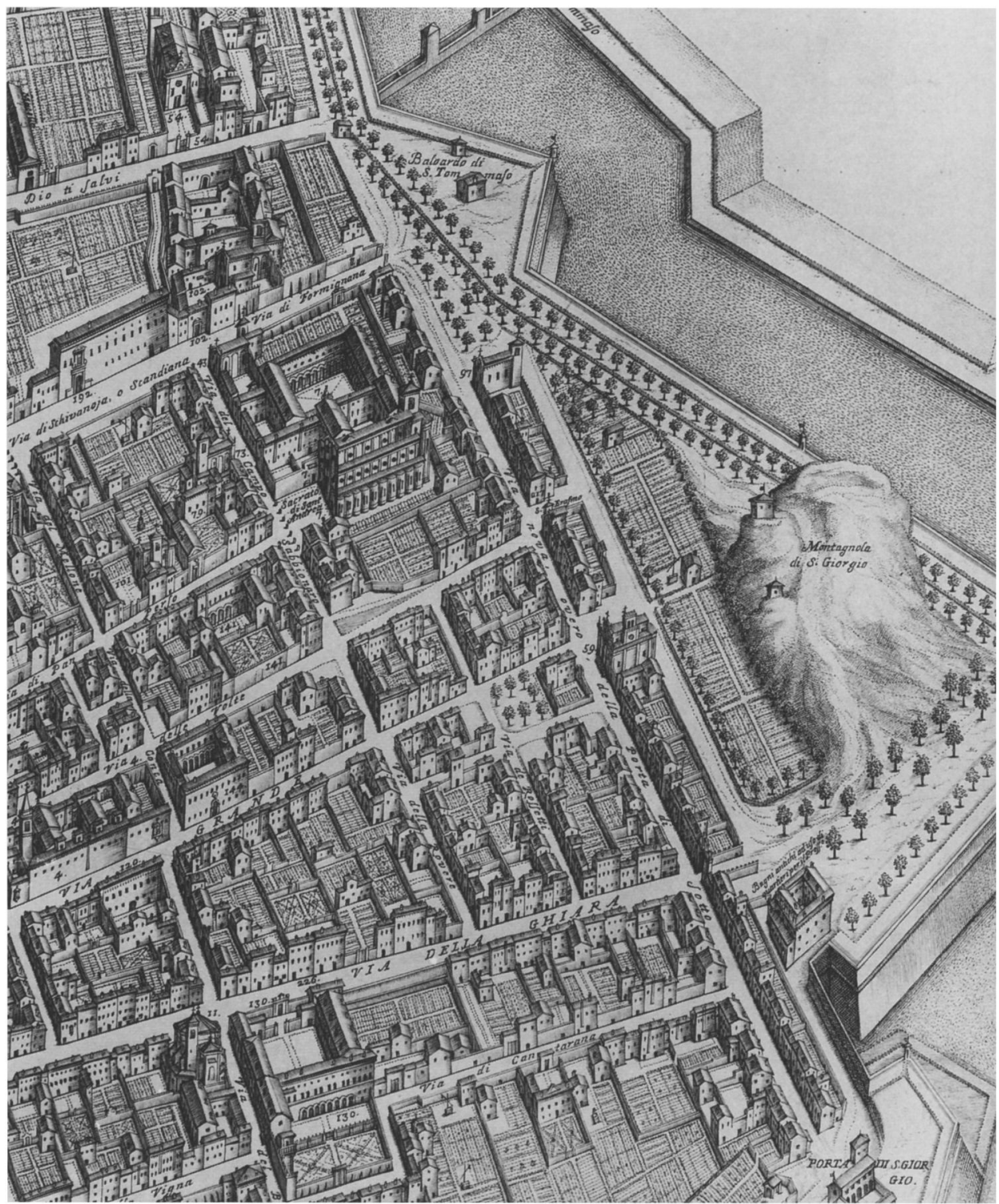

State. ${ }^{93}$ In the Costabili polyptych, the city's patron saint, ready in his gleaming armor, personifies the image of personal fortitude, communal strength, and spiritual leadership. In the opposite panel, Saint Sebastian is bound to a column with his armor cast at his feet; the pious centurion wears only the green cloak of hope, thereby underscoring his miraculous defiance of execution by arrows. The way in which Garofalo bathes the saint's nude body in an intense light that articulates the soft contours of his skin provides an image of wholeness. Garofalo's artifice contributes to the sense of delivery from suffering that finds its visual and conceptual parallel in the body of the Risen Christ in the pediment of the polyptych. ${ }^{94}$

The dialectical relationship between the Madonna and the saints allows us to associate the Costabili polyptych with Andrea Mantegna's Madonna of Victory (Musée du Louvre, Paris), a painting that commemorates Francesco II Gonzaga's rout of the French army at the Battle of Fornovo on July 6, 1495 (Fig. 15) ${ }^{95}$ Francesco Gonzaga, the marquis of Mantua and husband of Isabella d'Este (Alfonso's sister), declared that he sought refuge under the Virgin's protection at a pivotal moment in the conflict, when the Madonna revived his courage and ensured him victory. ${ }^{96}$ In the altarpiece Mantegna portrays the Madonna extending her hand and bestowing special favor on the marquis, who is dressed in full armor. Simultaneously, Saints Michael and George raise the Virgin's mantle to shield Francesco, who is portrayed as a warrior of God-the underlying value of "just war." Notably, Saints Andrew and Longinus, the patron saints of Mantua, accompany the Virgin in her festive bower of Paradise, teeming with exotic birds and fruits. Likewise, the way in which Dosso and Garofalo depicted the Madonna's blue robe and the green tapestry as spilling over the sides of the Virgin's throne serves both a formal and metaphoric function (Fig. 16). On the one hand, the triangle created by the fabrics functions as a stabilizing pyramid for the composition. On the other hand, when we consider the Virgin's gesture, her position under the prophetic inscriptions, and the way she touches Christ's orb of dominion, the open mantle and tapestry make a striking visual impact symbolizing protection. The warrior saints flanking the Madonna, as in Mantegna's altarpiece, complement the shielding nature of the Virgin, 


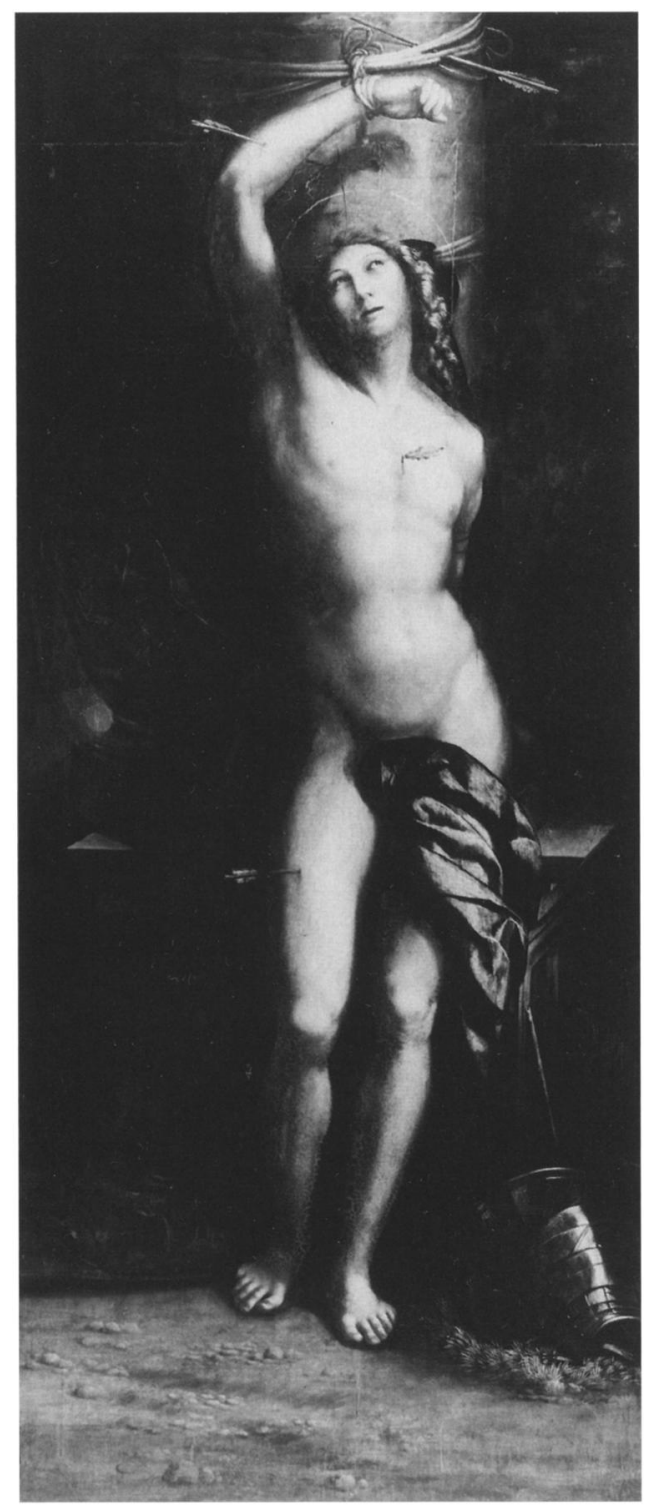

13 Detail of Fig. 1 with Saint Sebastian

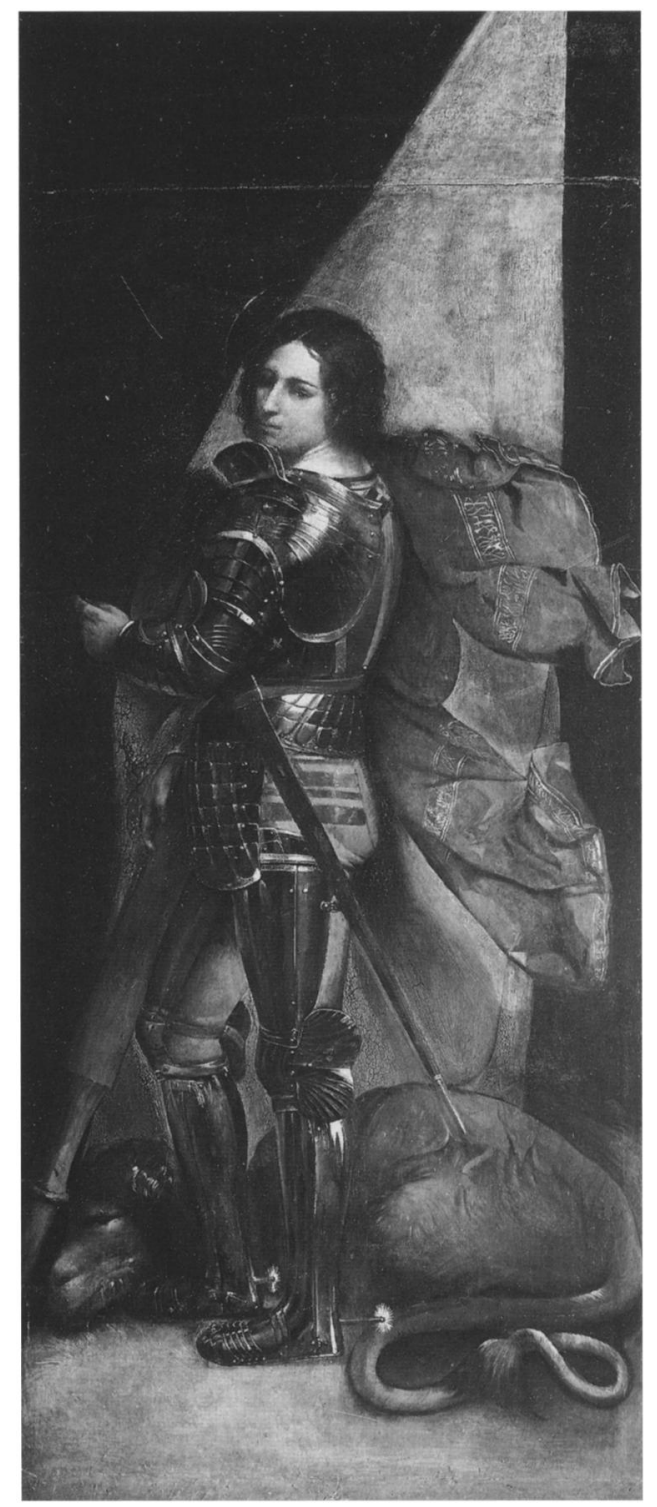

14 Detail of Fig. 1 with Saint George whom the Ferrarese believed intervened for their safety and protection. Prior to 1513, Dosso Dossi and Garofalo both worked in Mantua, and Costabili himself had visited the city twice on diplomatic missions. ${ }^{97}$ The artists and patron certainly knew and admired Mantegna's altarpiece, which was housed in a church built and dedicated to the Madonna della Vittoria. The thematic analogy between the Madonna of Victory and the Costabili polyptych helps us to understand the celebratory function of the Ferrarese altarpiece and establishes a pattern of Este iconography in the context of war as well.

\section{Friar Antonio Meli and the Vocational Pursuits of the \\ Eremitani}

The saints in the Costabili polyptych encourage various facets of theological discourse; this is especially true for the figure of Saint Augustine, who is dressed in the habit of an Austin hermit. Augustine's conversion to Christianity is marked by his discovery of monasticism as described in book 8 of his Confessions. ${ }^{98}$ Thus, the image carries strong vocational impli- cations for the Augustinian hermits of S. Andrea. As we have seen, the friars at $\mathrm{S}$. Andrea took an active role in cultivating the spiritual life of the Ferrarese community. In addition to Andrea Baura, Friar Antonio Meli, the prior general of the Eremitani congregation at S. Andrea, also proved himself a religious leader. Meli furthermore had close ties with Antonio Costabili, standing as witness to his last will and testament. In 1511 , the prior general composed a treatise on the reform of the female members of the Augustinian order. ${ }^{99}$ His bestknown and most important work is an exegetical treatise entitled Libro de vita contemplativa: Intitulato Scala del Paradiso, which he also dedicated to Lucrezia Borgia on April 10, 1513 (it was not published until 1527). ${ }^{100}$ The rich composition offers practical methods for leading a virtuous Christian life-from decorous dress codes to meditative practices-and contains prayers composed for the safety of Ferrara's rulers. The text is devoid of mysticism, calling for interpretative readings of the biblical text that explore its moral and didactic value- "per metaforica similitudine et imitatione." An exemplary and relevant exegesis involves the friar's study 
of Psalm 136, a lament and prayer for the vengeance of the people of God on Israel's enemies. Meli glosses Psalm 136 with chapter 2 of the Book of Isaiah, in which the prophet envisions an age of peace following God's judgment, and also with recourse to Saint Augustine's thesis on retributive justice. First, the friar explains that the adversaries of God are rocklike, noting for example that the name Esau, an enemy of God, means hard (duro), or lapidary (lapideo). Then he bids his readers-here, specifically female-to pray for divine retribution for those adversaries who bring harm to the allegorical (tropologica) city of Jerusalem, or the spiritual self:

Remember O Lord to take revenge on these men who are worldly, hard, rocklike, who were the destroyers of my allegorical city of Jerusalem, raising my sensible passions and sensual parts to the rebellion of reason, and the destruction of my spiritual parts. And what vengeance must be submitted? Nothing other than what God says through the prophet Isaiah. I will avenge myself on my enemies (that is killing and extinguishing the error in them and stimulating my assiduous faith) as Augustine expounds. ${ }^{101}$

While we shall momentarily explore the recurrence of the themes of retribution and deliverance with regard to their historical significance for Ferrara, the new Jerusalem, it is more important to note at this point how Meli's philological and allegorical approach to Scripture benefits the individual's spiritual self. The friar's teachings shed light on the message of salvation communicated by the Costabili polyptych. The Book of Isaiah remained central to the Church because it contains, according to Christian tradition, the whole story of Christ's life, from his birth to his death and subsequent resurrection. The theme of salvation is reinforced by the image of the Madonna who extends her hand over the Baptist in a tender gesture signifying protective motherly care. ${ }^{102}$ The Gospel of Saint John (1:6-8) recognizes the Baptist as the one divinely chosen to "give testimony of the light." He was the last prophet who verified Christ and foreshadowed his suffering for mankind's salvation. Furthermore, Isaiah 9:1-6 also had a liturgical function: these verses were read at the Mass of Christmas, thereby situating the high altarpiece within sacred and ordained ritual.

According to Meli's Scala del Paradiso, reading (lectione) was the first of four stages of spiritual development, followed by meditation (meditazione), prayer (oratione), and contemplation (contemplazione), the final step that leads to revelation. It is tempting to see the divine colloquium of saints in the central panel as practicing Meli's precepts of graduated difficulty by which the soul could progress from practical morality in quotidian life to the contemplation of the highest spiritual truth and the love of God: Saints Jerome and John the Evangelist, with texts in hand, represent lectione; the female saint in the right background and Saint Andrew, the patron saint of the church who directs the beholder to the Madonna and Child, invite oratione; while the saint behind Jerome with his hand to his mouth in a pensive gesture possibly stands for meditazione (Fig. 17). The Ferrarese painter Giovanni Battista Benvenuti, called Ortolano (ca. 1480/85-after 1527) adopted this gesture for the figure of Saint Demetrius in his altarpiece

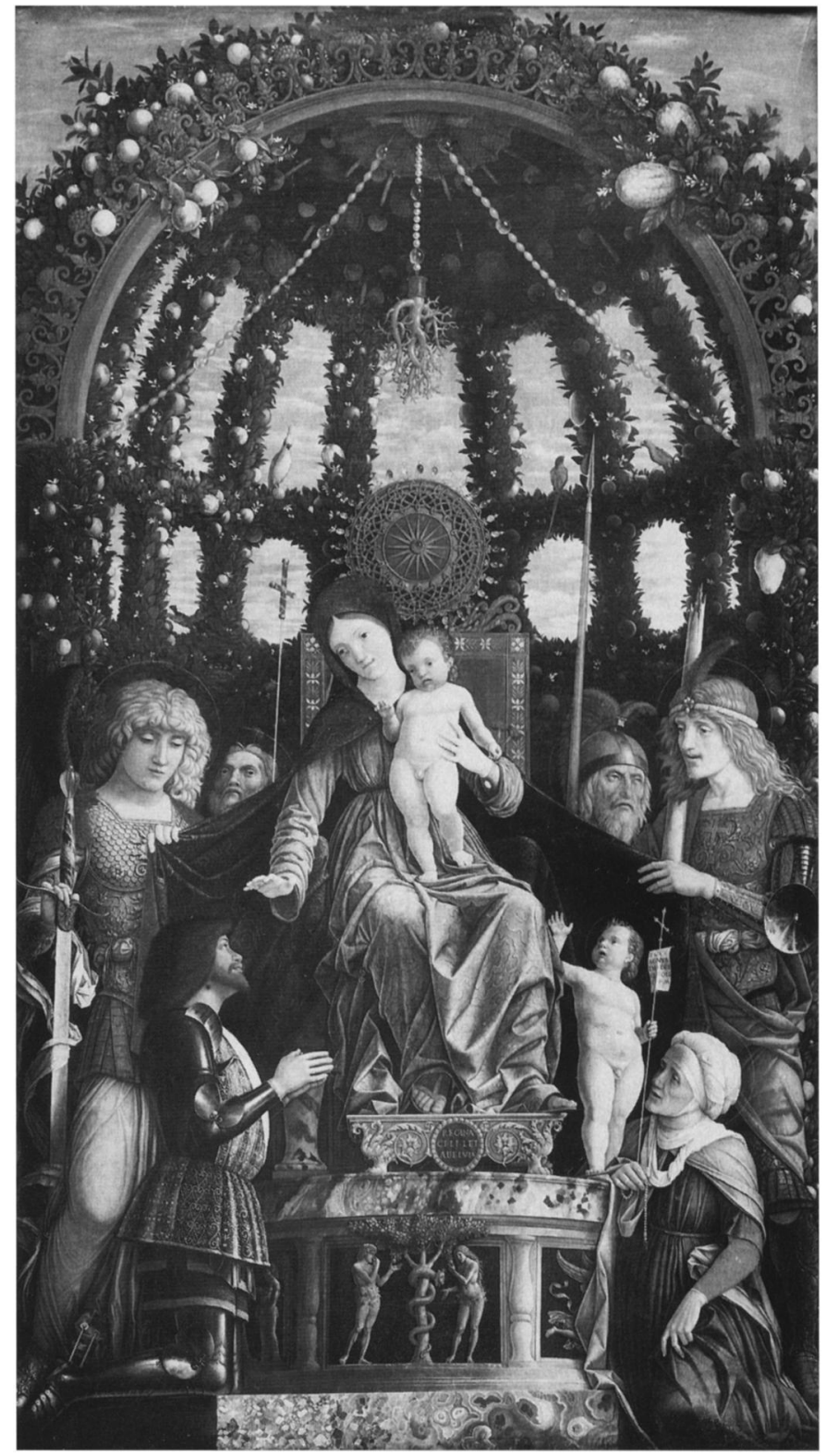

15 Andrea Mantegna, Madonna of Victory. Paris, Musée du Louvre (photo: Marburg/Art Resource, New York)

Saints Sebastian, Roch, and Demetrius of about 1520 (National Gallery, London), executed for the church of S. Maria in Bondeno, outside Ferrara (Fig. 18). ${ }^{103}$ Ortolano's employment of this gesture reveals how Ferrarese artists studied the Costabili polyptych as a visual paradigm of spiritual expression. Furthermore, the steps leading up to the Virgin seem to visualize Meli's metaphoric Scala del Paradiso, a spiritual ladder having been reached metaphorically by Saint Ambrose, who sits in the heavenly zone enrapt in contemplazione. The image of Saint Ambrose elevates the worshiper's mind to an inward vision through his intensity of concentration. ${ }^{104}$ Collectively, the saints in the Costabili polyptych exemplify the various behavioral methods designed to constitute a particularly spiritual subjectivity, manifesting what the friars believed was true and essential for the communal well-being. The rhetorical and liturgical force of the imagery suggests that Antonio Meli, along with Andrea Baura, may have assisted in devising the invention of the Costabili polyptych. 


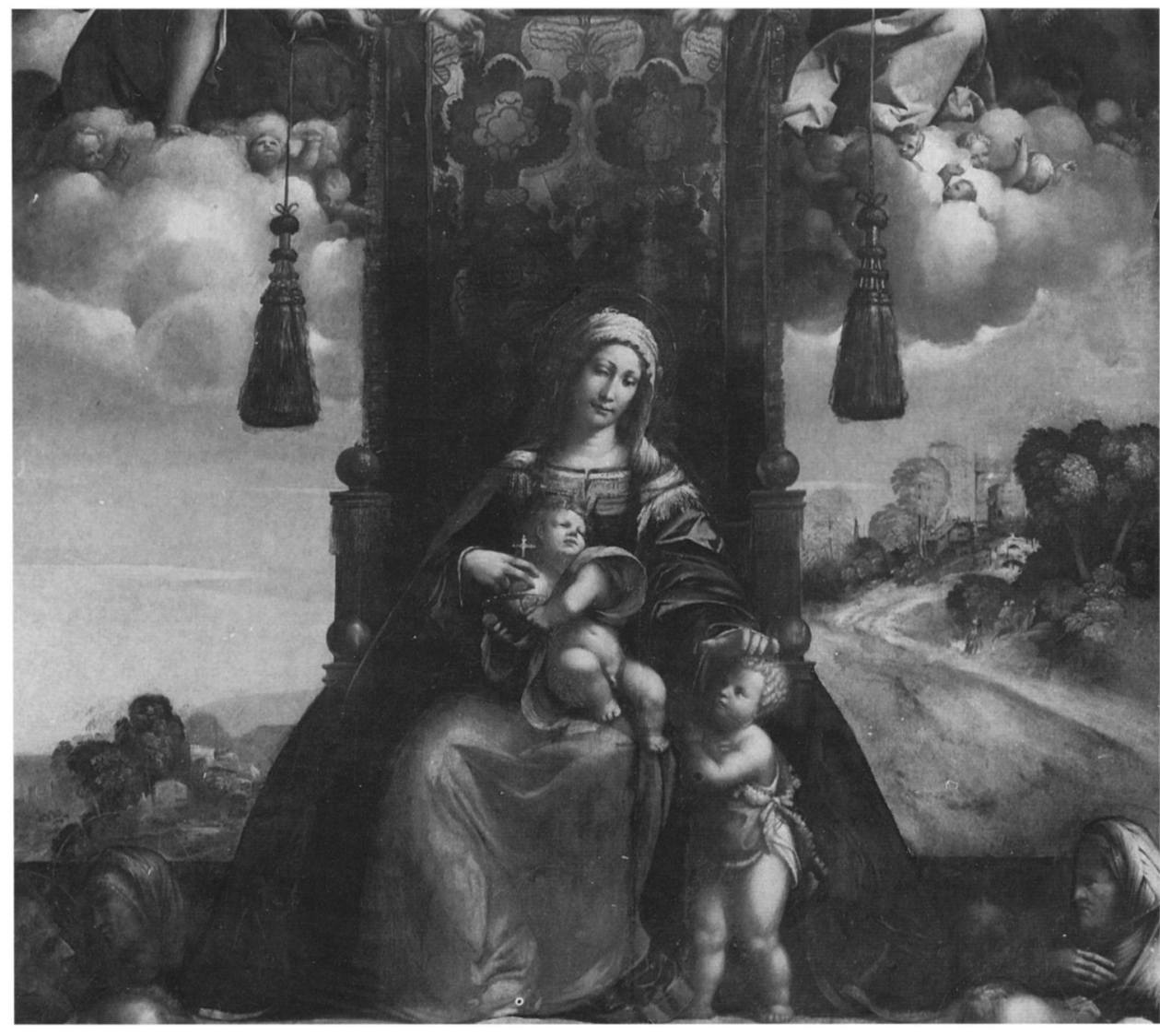

16 Detail of Fig. 1 with Madonna and Child

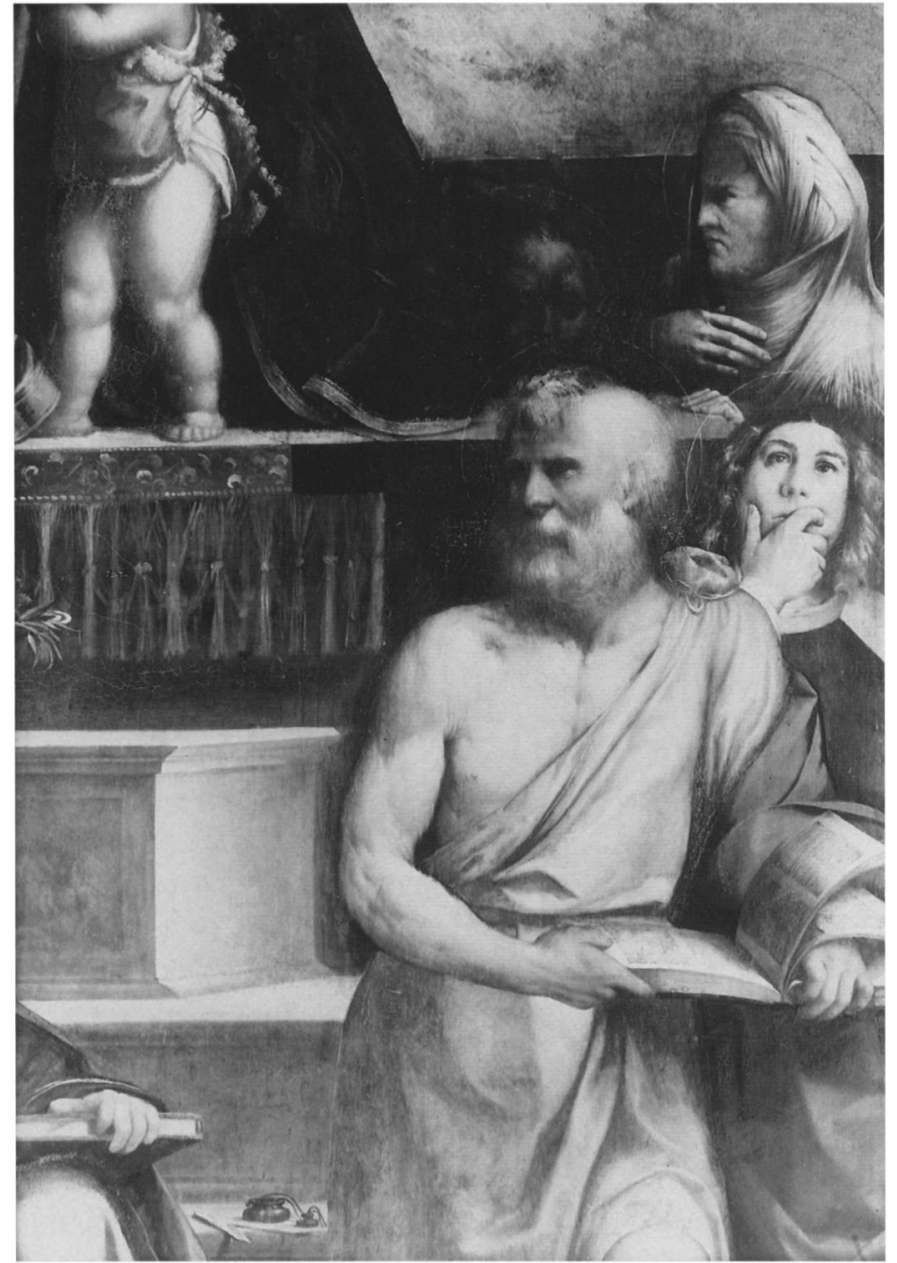

17 Detail of Fig. 1 with saint behind Jerome in central panel
An involvement in the altarpiece's invention by Meli may also explain the peculiar halo of fire around Saint Augustine's head (Fig. 19) as well as the central position of Saint John the Evangelist (Fig. 20). As the leader of the Eremitani in Ferrara, the friar would have been involved in the debate with the Canons Regular over the antiquity and primacy of their order-a debate that originated in the late fifteenth century and was in full force by the 1510 s throughout Italy. The confrontation centered on which order best developed Augustine's theology and "Rule," thereby achieving the ideal Christian life, which in turn led to a dispute as to whether images of Augustine should show the saint dressed in the habit of an Austin canon or of an Austin hermit. ${ }^{105}$ To corroborate their argument, the hermits turned to the eschatological writings of Joachim del Fiore (ca. 1135-1202), who had been the first to interpret the Book of the Apocalypse in light of contemporary figures and events. ${ }^{106}$ Such learned sixteenth-century Eremitani as Egidio da Viterbo and Silvestro Meuccio of S. Cristoforo della Pace (Venice) made use of Joachim's Expositio in Apocalypsim, which contains a famous prophecy of a new order of spiritual men, dressed in black (nigris vestibus), who will be called from the contemplative to the active life. The following commentary by Joachim on the various angels in chapter 14 of the Book of the Apocalypse served as testimony to the authority of the hermits and was believed to foreshadow their order: "They shall increase and their fame shall spread abroad; they shall preach the faith and defend it until the consummation of the world in the spirit and power of Elias. There shall be an order of hermits living like angels, whose life shall be as a burning fire to consume all tares." 107 The startling image of Saint August- 
ine in the Costabili polyptych, pointedly dressed as a hermit, and whom the painter Dosso Dossi has punctuated with fervent brushstrokes for his halo of fire, carries an especially charged meaning as it ostensibly visualizes Joachim's prophecy. Dosso's virtuosic display cannot be explained by appealing to visual precedents in Rome or Venice; rather, this unparalleled detail caters to an audience of clerics who fashioned their identity in the image of angelic fire. Considering the artist's representations of Saint Augustine and Saint George, small wonder that Luigi Lanzi, who in his Storia pittorica della Italia was the first to recognize an autonomous Ferrarese school of painting, championed Dosso for assimilating the "antico" manner of Francesco Francia and Lorenzo Costa into his own "moderno" manner by means of his novel inventions and daring exploration of color and light. ${ }^{108}$

\section{Pope Julius II and Divine Retribution}

Until now I have not claimed that the Costabili polyptych takes a direct antipapal stance. Yet contemporary attacks on Pope Julius II's character and authority are relevant to our analysis of the most peculiar feature of the altarpiece: the fiery hail in Augustine's cell.

When Alfonso I d'Este sought to legitimate his position as an excommunicated ruler in crisis, he and his courtiers initiated a campaign designed to characterize Julius II as an impetuous tyrant, one warranting retributive justice. Alfonso's sumptuous Book of Hours (ca. 1505-12), ${ }^{109}$ executed at the time Ferrara was plunged into war with Rome and Venice, provides a bitter commentary on the sufferings of Ferrara at the hands of the pope. A historiated leaf in the Calouste Gulbenkian Museum, Lisbon (inv. L.A. 149, fol. 13r), depicts Alfonso dressed in full armor and kneeling in prayer to God set inside the initial $Q$, whereby the duke fashions himself as a warrior under God's command. Certain illuminations from his Book of Hours condemn the duke's enemies, the most striking example being a folio accompanying the Vigils of the Dead (Fig. 21). In this full-page miniature now in the Strossmayerova Galerija, Zagreb, the illuminator Matteo da Milano

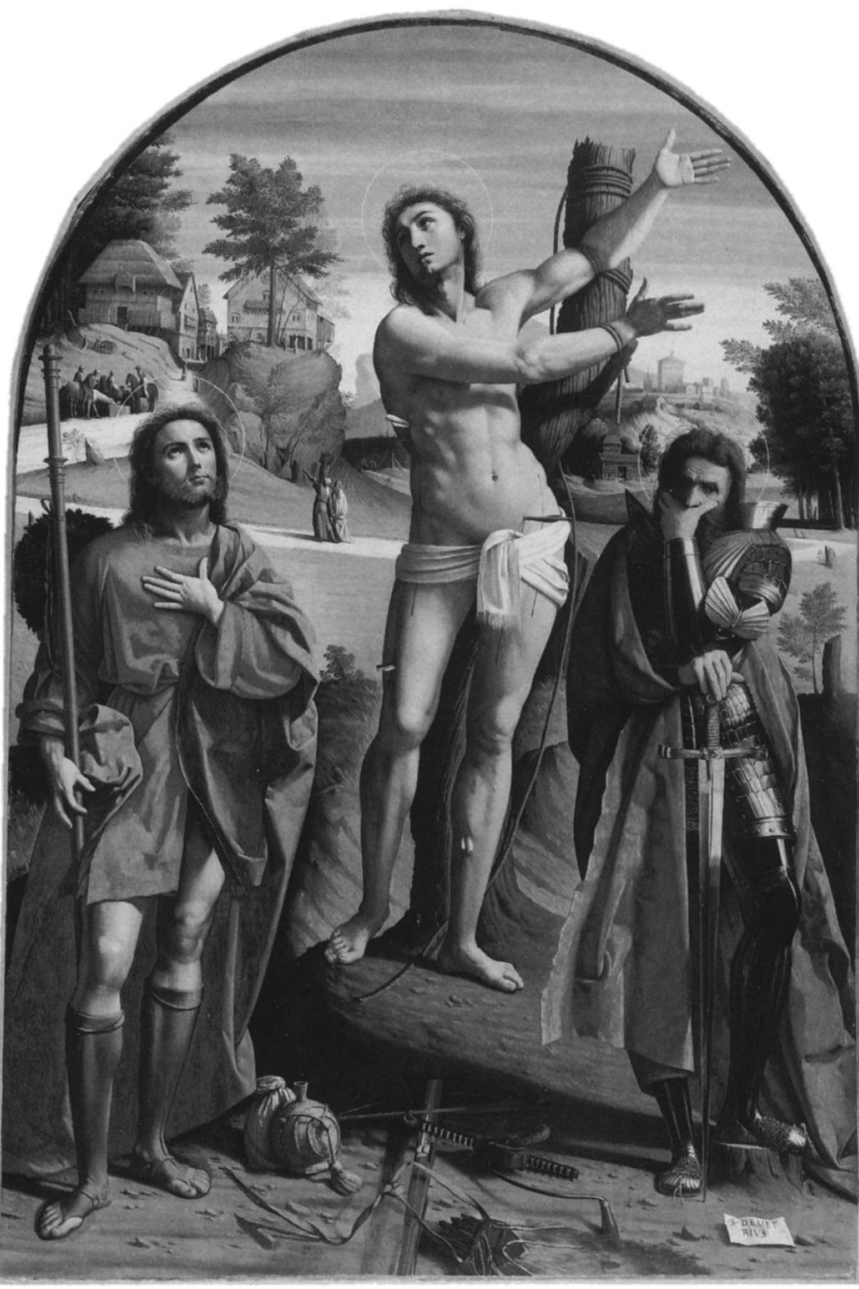

18 Ortolano, Saints Sebastian, Roch, and Demetrius. I.ondon, National Gallery

interprets the Triumph of Death as a false pope clutching his money bag while fleeing from the skeletal personification of Death. A devil standing behind the pope holds up a book

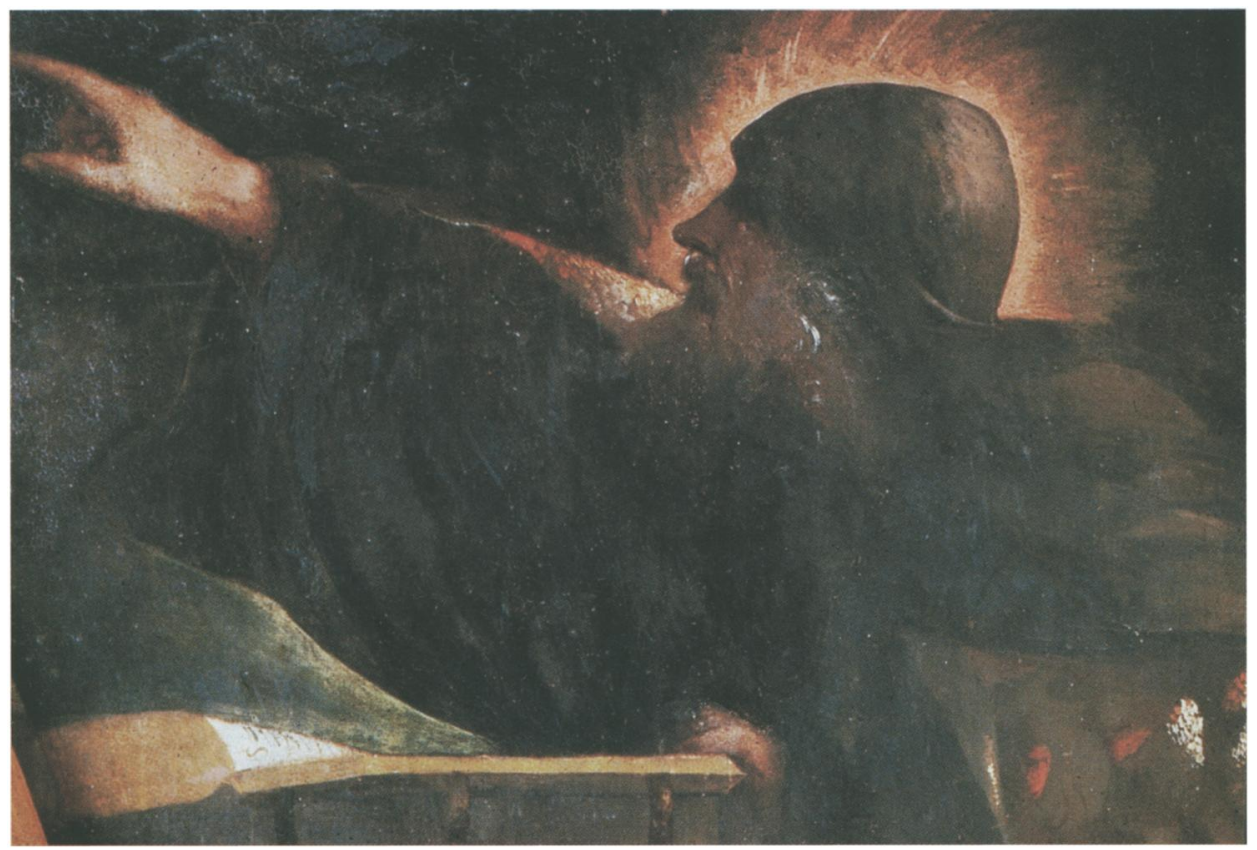




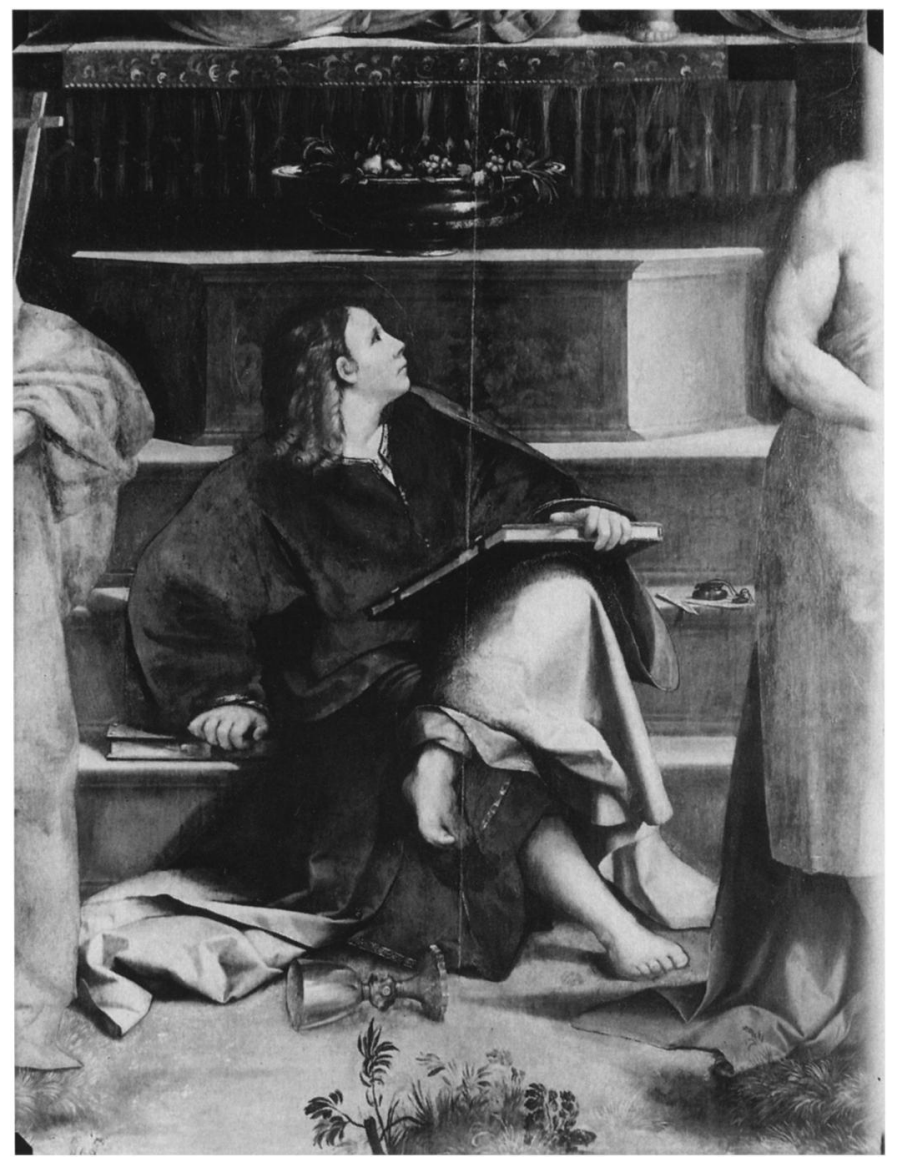

20 Detail of Fig. 1 with Saint John the Evangelist

inscribed with the words "Vide quanta sunt s[c]elera...." (Observe how many are the impious deeds). Under this macabre Dance of Death lies a mass of bodies, while in the background fire consumes a building. Jonathan Alexander has rightly interpreted this image in the context of Alfonso's intense enmity toward Pope Julius II. ${ }^{110}$ The bearded pope in the illumination lends further proof that the figure is meant to be seen as a satirical portrait of Julius II, who began growing his beard in October 1510. ${ }^{111}$ Matteo's highly sophisticated illumination thus damns the vengeful, greed-driven pontiff and his quest for temporal dominion over Italy. The keen rhetorical deployment of the Triumph of Death enabled the duke of Ferrara to submit the wicked deeds of the pope to God's judgment.

Accordingly, if we consider the practice of eschatological readings of historical events and signs, the startling image of flames shooting from within Augustine's cell in the Costabili polyptych may in fact figure as divine retribution against Ferrara's adversaries. ${ }^{12}$ Notably, the saint points to these flames with a gesture that imitates that of the spiritello who calls attention to the inscriptions, the Word of God, in the central panel. The authoritative text on retribution is once again the Book of Isaiah. In his vision of Judgment Day, the prophet foresees retribution for the wicked, exclaiming God's revelation with thunderous force (Isaiah 66:15-16):

For behold the Lord will come with fire [in igne veniet], and his chariots are like a whirlwind, to render his wrath in

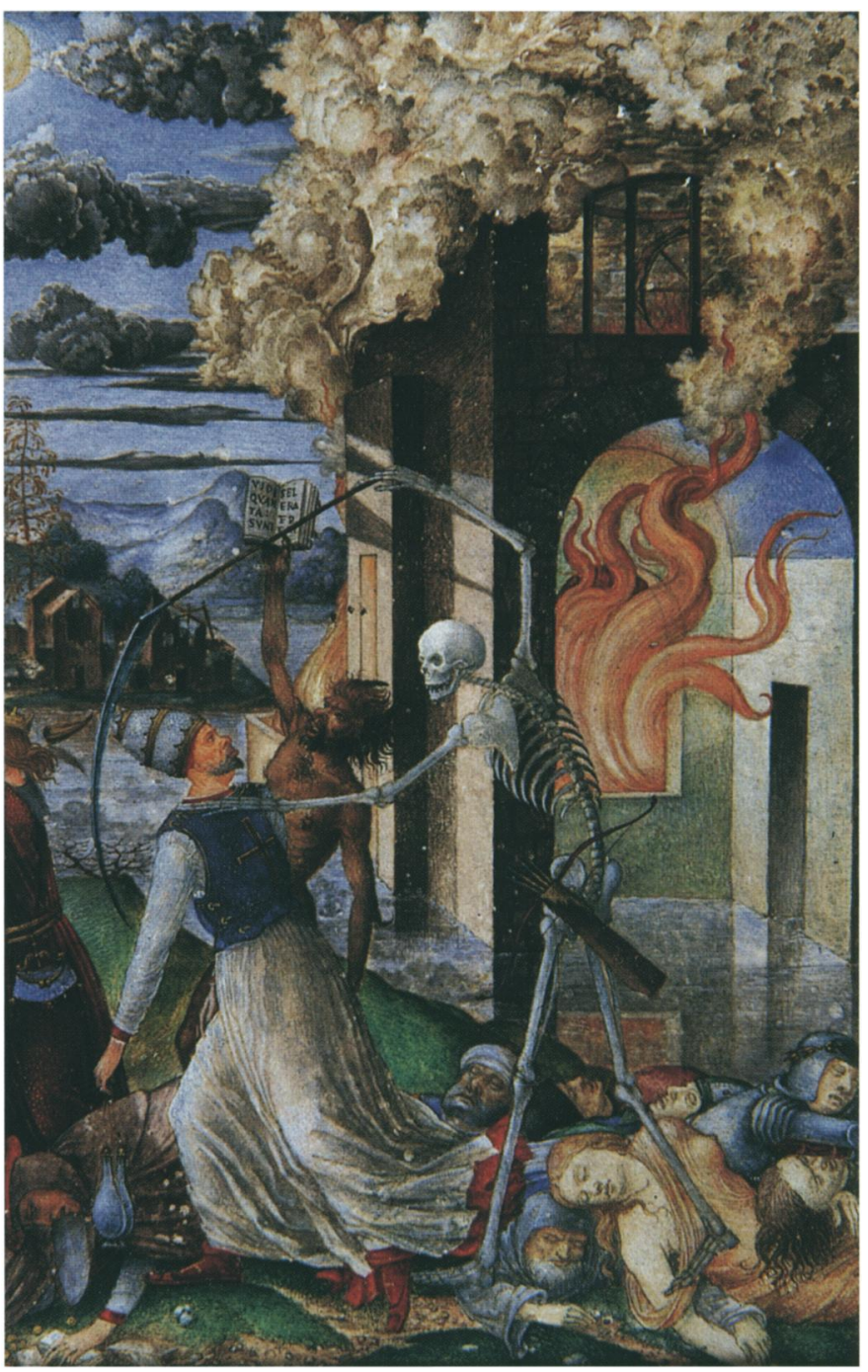

21 Matteo da Milano, leaf from the Book of Hours of Alfonso I, Death Pursuing a Pope. Zagreb, Strossmayerova Galerija

indignation, and his rebuke with flames of fire [in flamma ignis].

For the Lord shall judge by fire, and by his sword unto all flesh, and the slain of the Lord shall be many.

As Augustine relates in his Confessions (9.5), it was Saint Ambrose who directed him to read Isaiah, whose prophecy became an important source for Augustine's thesis on retributive justice in his De civitate Dei. In his exegesis of Isaiah 66:15-16, Augustine discusses the prophet's blending of figurative and literal expressions, explaining by "fire," "whirlwind," and "sword" that Isaiah means ". . . the punishment of judgment; for he savs that the Lord himself shall come as a fire, to those, of course, for whom his coming is a punishment." 113 According to the prophet, God shall comfort the saved in Jerusalem, a place of heavenly bliss and peace.

The theme of retribution by fire figures even more prominently in Andrea Baura's exposition on Psalm 17, a text that also provides a useful gloss for interpreting the Saint Augustine panel. In Psalm 17:13-16, David sings of his delivery from his enemies through God's intervention, whom he envisions as coming in "hail and coals of fire [grando et carbones ignis]." According to Baura, the hail and coals of fire signify bloody 
battles, explaining in his exposition that God must eliminate the wicked through bloodshed in order to bring about a purified Church. The friar's interpretation accords with the doctrine of bellum justum, since battle is necessary to obtain divine "justice [iustitia]" and "peace [pace]":

Grando et carbones ignis: that is, God will send hail and coal of ardent fire, which will be bloody battles.... Et fulgura multiplicavit: And God will multiply over a long time these lightnings, or these afflictions, until he will have troubled them. . . Et apparuerunt fontes aquarum: And alas God will make appear the fountains of his sacred waters, and there will appear through all the Church the fountain of peace, the fountain of clemency, the fountain of justice, the fountain of grace, charity, and faith, and all the other virtues. ${ }^{114}$

The metaphor of justice and peace pouring forth like a fountain recalls the imagery of Isaiah $66: 12$, whereby God will comfort the saved in Jerusalem and "will bring upon her as it were a river of peace [declinabo super eam quasi fluvium pacis]." Moreover, there appears to be a quite specific relationship between Psalm 17 and the hail of fire in the Saint Augustine panel. Conventionally, one would expect to see golden rays of divine light inspiring Augustine or signaling his conversion. Here, however, Dosso offers a compelling visualization of God's potential fury, interpreting Scripture, be it Isaiah or the Psalms, according to his own personal, self-conscious stylistic devices. Such artifice may well have offered the Ferrarese audience, recently liberated from the wrath of a warrior pope both physically and spiritually, psychological reassurance. According to Saint Augustine, a "spiritual vision," such as that of the prophet Isaiah, is a revelation through symbols and divine signs. ${ }^{115}$ The pictorial transmission of these signs connects the topology of the Costabili polyptych to such apocalyptic images as Sandro Botticelli's Mystic Crucifixion of about 1497 (Fogg Art Museum, Cambridge, Mass., Fig. 22).116 The artist shows Mary Magdalen embracing Christ's crucifix before dark storm clouds that release burning torches-a scourge summoned by God the Father, who appears in the sky along with angels holding white shields blazoned with red crosses. The imagery corresponds, in part, to the sermons of the Dominican Girolamo Savonarola (1452-1498), who was born in Ferrara and later resided at the convent of S. Marco in Florence. Especially relevant for Botticelli's invention is Savonarola's The Compendium of Revelations, a text composed in 1495 and filled with related apocalyptic visions warning against the punishment for sins and corruption that God would inflict on Florence. ${ }^{117}$ In the background of his picture Botticelli depicts the city of Florence shining like a new Jerusalem purified after God's wrath. Likewise, Dosso and Garofalo have depicted a serene, hilly landscape and city set under tranquil skies behind the Virgin's throne. Given the close rapport among the Eremitani, the Este, and Antonio Costabili, reading the imagery in the Costabili polyptych as symbols of Ferrara's triumph and the downfall of its enemies would have amplified rather than conflicted with its religious import.

On or around May 1, 1514, while Dosso and Garofalo were in the process of completing the altarpiece for Antonio
Costabili, lightning struck the church of S. Andrea, with one bolt blasting the head off the crucifix at the high altar and another hitting the pilaster that housed the tabernacle. ${ }^{118}$ The lightning may have been seen as a flagellum Dei, a reminder to all that God scourges the wicked-an image vividly evoked in the Book of Isaiah as well as in the Psalms and, moreover, visualized in the Costabili polyptych. ${ }^{119}$ That the Ferrarese did indeed envision the death of Pope Julius II as a sign of God's punishment is further evidenced by an epigram composed by the eminent Ferrarese rhetorician Celio Calcagnini (1479-1541). Calcagnini earned his doctorate in canon law, and his rhetorical skills and sophisticated wit won him the positions of Este court historian, chair of the faculty of rhetoric at the University of Ferrara, and apostolic notary. ${ }^{120}$ The rhetorician was also a close friend of and artistic advisor to Antonio Costabili, devising the invention for Garofalo's frescoes depicting the myth of Anteros in the Stanza del Tesoro of Costabili's palace. ${ }^{121}$ In a classically inspired epigram entitled "De obitu Iulii II pontifex maximus," composed in 1513, Calcagnini admonishes Pope Leo X to keep peace with Ferrara by reminding him of his predecessor's fate in the following manner:

Hard Julius had stirred up dreadful arms against Alfonso, when God knocked away the weapons from his hands. Leo tried to take up again those same weapons, and he himself sensed straight away the anger of the gods. Whosoever you will be who is bid to sit upon this sacred throne, be mindful that peace is characteristic of your office. However, if an evil disposition or a mad passion for dominance drags you into criminality and back again into forbidden war, the gods as avengers of wickedness will stir their own weapons again so that future generations may learn by your example. ${ }^{122}$

Calcagnini absorbs Divine Providence into the political fortunes of the Ferrarese community. His reaction to the defeat of Pope Julius II, here envisioned as a result of God's anger, encourages a reading of the message of peace through strength communicated by the Costabili polyptych as a gloss on Ferrara's conflict with Rome. Accordingly, the responsive practices of the Ferrarese audience may also explain the absence of any papal references from the altarpiece, namely Saints Peter and Maurelius, the patron bishop of Ferrara who was anointed by the pope. ${ }^{123}$ Even though humanists in Italy hailed Leo X as "Rex pacificus," the Ferrarese remained mindful of the motives of Christ's terrestrial vicars. ${ }^{124}$

\section{Prospects for Future Inquiry}

My investigation into the Costabili polyptych aimed to provide a framework in which to understand how the representational techniques at work enable a cognitive as well as affective experience of the altarpiece. Concerning the issue of date, even if it were proven that Dosso's contribution extended into the $1520 \mathrm{~s}$, there can be no doubt that the altarpiece was wholly conceived and the painting underway by 1513 . Interpreting the artistic development of Dosso and Garofalo is immensely challenging, but too often their innovations have been seen as merely symptomatic of the artists' submission to more powerful artistic "influences" generated in Venice and 


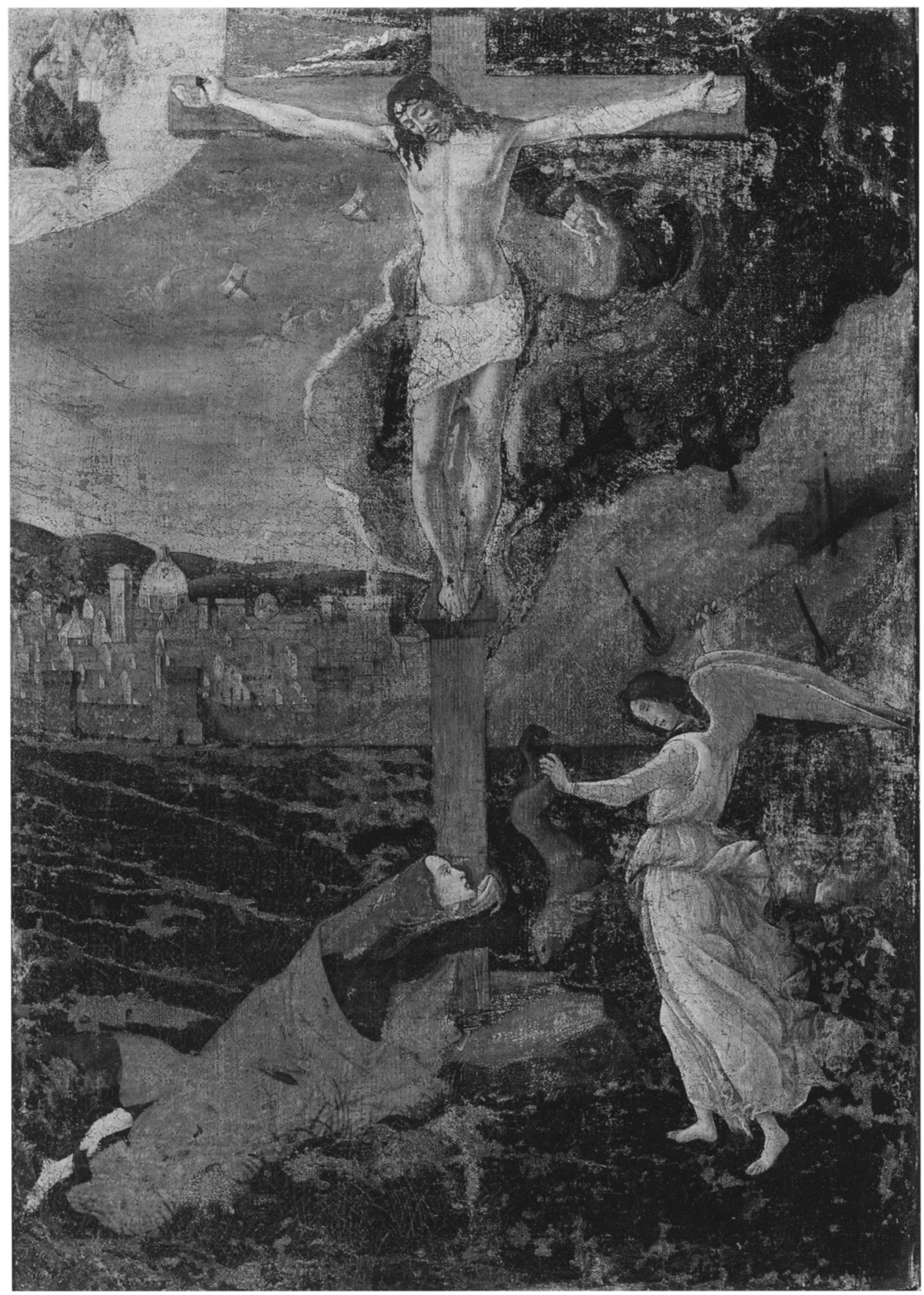

22 Sandro Botticelli, Mystic Crucifixion. Cambridge, Mass., The Fogg Art Museum, Harvard University Art Museums, Gift of the Friends of the Fogg Art Museum (photo: @ President and Fellows of Harvard College)
Rome. ${ }^{125}$ Research into the efficaciousness of the styles of Dosso and Garofalo, the public and private currency of their art, is necessary in order to put questions regarding chronology and stylistic hierarchies into sharper focus. In this regard, more needs to be said concerning Antonio Costabili's strategic pairing of the singularity of Dosso's manner with the more pietistic language of Garofalo. We know that Costabili played an instrumental role in establishing the Lombard painter Boccaccio Boccaccino (ca. 1467-1525) in Ferrara between 1497 and 1500. ${ }^{126}$ Garofalo trained under Boccaccino, as Vasari himself reported and documents recently discovered by Franceschini confirm. ${ }^{127}$ By 1513, the patron had already gained the artistic sensibility to orchestrate the collaboration between Dosso and Garofalo, who together amplified the artistic traditions of Ferrara while they discovered a new and dramatic pictorial vocabulary that expressed the spiritual and civic values of their Ferrarese audience. The promise of peace offered by the Costabili polyptych, designed at the close of Ferrara's participation in the Cambrai Wars, corresponds with a promised Golden Age, both divine and secular, that allows the arts to flourish.

\section{Appendix}

Francisci Bernardini Bovii Ferrariensis (Francesco Bovio), "Carmina (Elegiae, Epigrammata, Tumuli)," BAF ms Cl.I.69, fol. 1r-1v:

Ad Illibatam Virginis Imaginem ad Portam Inferiorem (1511) 
Magna parens, hominum semper miserata labores, Inferni caput ingentis quae conteris anguis,

Stelliferique piis reseras penetralia coeli,

Si tua non nobis summo sine nomine Imago

Nuper adest, miseris libeat succurrere rebus:

Aspicis, a teneris quantum male plectimur annis,

Mens mea perpetuis, quantisque in fluctibus erret.

Namque viri causas fas non est scire profundas,

Implicitasque uelut prisci nodamina Gordi.

At tibi Diva parens quaecunque obducta tenebris

Lumina nostra precor taetris demersa sub umbris

Cor miserum comitata, leva iam ad sidera Mater,

Ut mihi iam liceat tantis exsurgere monstris,

Longaque iam valeam post nubila cernere Solem.

Si Deus immensi specimen te fecit olympi

Ut miseris sidus niteas mortalibus, ergo

Cerne meos gemitus, precibusque movere pudicis.

Non aurum petimus, nec honor sedet, atque voluptas

Summa precum Deus et virtus, charitasque benigna

Nostrarum fuerit. Vivens vivaciter ergo

Fac colere ut valeam, plenoque in pectore numen.

Protinus ut tabulae vigeant mandata secundae,

Atque satis tandem charis ita fiat amicis;

Incolumen me redde precor, reducemque relictum;

Hoc quia Naturae bene congruit, atque saluti:

Atque preces in se pariter concludit honestas

Intemerata tuo pendemus limine Virgo. ${ }^{128}$

(To the Untouched Image of the Virgin at the Porta di Sotto: Great Mother, you who have always had mercy upon the toils of man, and you who crush the head of the giant infernal serpent, and you who reveal the mysteries of the starry heavens to the devout, if for the very best of reasons your image is not recently present to us, it may be pleasing to you now to assist our wretched circumstances. Alas you see how awfully we are punished in these tender years, and in what great and unending waves my mind wanders astray. It is not proper to know the great causes of man, tangled up like the knot of ancient Gordius. Still O Divine Mother I beseech you, lift to the stars our eyes, accompanying our miserable hearts, that are immersed under foul shadows and covered in darkness, that I may now be permitted to raise myself against such great wickedness, and that I may have the strength to discern the sun after the long overcast. If God made you a manifestation of immense Olympus, so that you might shine out like a star for us miserable mortals, therefore, observe my groans, be moved by my chaste prayers. We do not seek gold, nor does honor take a seat; and the highest pleasure of our prayers will have been God and virtue and benign charity. Thus while alive bring it about that I have strength to cultivate your godhead and name with a full heart. So let the mandates from the second set of tablets flourish forthwith, and finally let there thus be enough grace for my dear friends. I pray, restore me unharmed, whole, and renewed, because this fits well with nature and with salvation. And equally it encloses within itself this honest prayer, $\mathrm{O}$ chaste Virgin, we dangle at your threshold.)

Giancarlo Fiorenza is assistant curator of European Painting and Sculpture before 1900 at the Toledo Museum of Art. He is completing his doctoral dissertation on the art of Dosso Dossi at the Johns Hopkins University [The Toledo Museum of Art, P.O. Box 1013, Toledo, Ohio 43697].

\section{$1 \quad$ Frequently Cited Sources}

BAF: Biblioteca Ariostea, Ferrara

Augustine, Saint, De civitate Dei contra paganos (The City of God against the Pagans), trans. William M. Green, Loeb Classical Library (Cambridge, Mass.: Harvard University Press, 1978).

Ballarin, Alessandro, Dosso Dossi: La pittura a Ferrara negli anni del ducato di Alfonso I, register of documents by Alessandra Pattanaro, catalogue by Vittoria Romani, 2 vols. (Cittadella: Bertoncello Artigrafiche, 1994-95).

Bayer, Andrea, ed., Dosso Dossi: Court Painter in Renaissance Ferrara, exh. cat. (New York: Metropolitan Museum of Art, 1998).

Bentini, Jadranka, ed., La Pinacoteca Nazionale di Ferrara: Catalogo generale (Bologna: Nuova Alfa, 1992).

Ciammitti, Luisa, ed., Garofalo e Dosso: Ricerche sul Polittico Costabili (Venice: Marsilio, 1998).

Ciammitti, Luisa, Steven F. Ostrow, and Salvatore Settis, eds., Dosso's Fate: Painting and Court Culture in Renaissance Italy (Los Angeles: Getty Research Institute for the History of Art and the Humanities, 1998).

DBI: Dizionario Biografico degli Italiani (Rome: Istituto della Enciclopedia Italiana, 1960-).

Fioravanti Baraldi, Anna Maria, Il Garofalo: Benvenuto Tisi pittore (c. 1476-1559); Catalogo generale (Rimini: Luisè, 1993).

Franceschini, Adriano, Artisti a Ferrara in età umanistica e rinascimentale: Testimonianze archivistiche, pt. 2, vol. 2, 1493-1516 (Ferrara: Corbo, 1997).

, 1995/1998, "Dosso Dossi, Benvenuto da Garofalo, e il polittico Costabili di Ferrara," Paragone, nos. 543-45 (1995): 110-15; published in English, with additions, as "Dosso Dossi, Benvenuto da Garofalo, and the Costabili Polyptych in Ferrara," in Ciammitti et al., 143-51.

Guarini, Marc' Antonio, Compendio historico dell'origine, accrescimento e prerogative delle chiese, e luoghi pii della città e diocesi di Ferrara, 2 vols. (Ferrara: Gli Heredi di Vittorio Baldini, 1621).

Humfrey, Peter, and Mauro Lucco, "Dosso Dossi in 1513: A Reassessment of the Artist's Early Works and Influences," Apollo 147 (1998): 22-30.

Lanzi, Luigi, Storia pittorica della Italia dal risorgimento delle belle arti fin presso al fine del XVIII secolo (1809), ed. Martino Capucci, 3 vols. (Florence: Sansoni, 1968).

Pattanaro, Alessandra, "Il testamento di Antonio Costabili: Per il polittico di Dosso e Garofalo già in Sant'Andrea a Ferrara," Arte Veneta 43 (1989-90): $130-42$.

Scalabrini, Giuseppe Antenore, Memorie istoriche delle chiese di Ferrara e de' suoi borghi (Ferrara: Carlo Coatti, 1773).

Vasari, Giorgio, Le vite de' più eccellenti pittori, scultori ed architettori (1568), ed. Gaetano Milanesi, 9 vols. (Florence: Sansoni, 1906).

Zerbinati, Giovanni Maria, Croniche di Ferrara: Quali comenzano del anno 1500 sino al 1527, ed. Maria Giuseppina Muzzarelli (Ferrara: Deputazione Provinciale Ferrarese di Storia Patria, 1989).

\section{Notes}

I wish to thank Professors Charles Dempsey, Elizabeth Cropper, and Salvatore Camporeale for reading a version of this essay, and the anonymous readers of the Art Bulletin for their helpful comments. Adriano Franceschini and Don Enrico Preverada provided kind assistance in the archives and with transcriptions of documents. I am very grateful to Dott.essa Grazia Agostini for giving me permission to study the Costabili polyptych on scaffolding. I am also indebted to Anthony Colantuono and Stephen Campbell for sharing their insight into Ferrarese art and culture. Research for my dissertation on Dosso Dossi, from which this essay derives, has been supported by a Jane and Morgan Whitney Fellowship from the Metropolitan Museum of Art and two Travel Fellowships from the Samuel H. Kress Foundation.

Where necessary, I have adapted Italian and Latin texts according to modern convention, spelling out abbreviations, adding diacritical marks, and replacing $\mathrm{u}$ for $\mathrm{v}$ and $\mathrm{i}$ for $\mathrm{j}$. Unless otherwise indicated, all translations are mine.

1. Bentini, 126-28, inv. nos. 189-94; Vasari, vol. 6, 457-69, esp. 462. Although Vasari does not mention Dosso Dossi specifically in connection with the Costabili polyptych, he nevertheless recognizes that Garofalo collaborated with Dosso (and later with his brother Battista Dossi) on various projects: "lavorando ... . alcune in compagnia de' Dossi."

2. Andrea de Marchi, "Dosso versus Leonbruno," in Ciammitti et al., $158-61$.

3. Vasari speaks of his two visits to Ferrara and his friendship with Garofalo in the combined Lives of Garofalo and Girolamo da Carpi; Vasari, vol. 6, 468-69, 476. See also Wolfgang Kallab, Vasaristudien (Vienna: Karl Graeser; Leipzig: G. B. Teubner, 1908), 70-71; and Patricia Rubin, Giorgio Vasari: Art and History (New Haven: Yale University Press, 1995), 127, 369.

4. The issue of Garofalo's sojourn(s) to Rome has yet to be clarified. It appears that the artist was in Rome by 1512 (or even earlier according to 
Vasari), but returned to Ferrara toward the end of that year, at which time he was working for Duke Alfonso I d'Este. Garofalo's Neptune and Minerva (Staatliche Kunstsammlungen, Gemäldegalerie Alte Meister, Dresden), which has a provenance from the ducal castle of Ferrara, is dated Nov. 1512; see Fioravanti Baraldi, 112-13; and the entry by Concetto Nicosia in Sovrane passioni: Le raccolte d'arte della Ducale Galleria Estense, ed. Jadranka Bentini (Milan: Federico Motta, 1998), 316.

5. Vasari, vol. 6, 463: “. . . la Vergine in aria col Figliuolo in collo, e di sotto alcun' altre figure."

6. Bentini, 130, inv. no. 148; Fioravanti Baraldi, 116.

7. Vasari, vol. 6, 463, states that Garofalo always longed to return to Rome where he had studied under Raphael the "modern manner." Luigi Lanzi judged the Roman manner in Garofalo's art to be so important that he also discussed the Ferrarese painter under the "Scuola Romana," as an assistant of Raphael; Lanzi, vol. 1, 317: "Imitò da Raffaello il disegno, le fattezze, la espressione, e molto anche del colorito; sennonché vi aggiunse non so che di acceso e di forte che par derivato dalla sua scuola" (He [Garofalo] imitated Raphael in disegno, character features, expression, and to a great extent in his coloring as well, although he added a certain vividness and boldness derived from his own [Ferrarese] school).

8. Franceschini, 1995/1998; 1997, doc. 1013: u, z, bb, cc

9. Franceschini, 1995, 114 n. 12, 1998, 149 n. 12; 1997, doc. 1013: u: "Al Magnifico Messer Antonio di Costabili lire trenta de marchesani per compto de suo salario, et per Sua Magnificientia a Dosso da la Mirandola et Benvegnudo da Garofalo picturi contanti a bon compto de una tavola che depinzono alo altaro grande de la chiesa de Santo Andrea in Ferrara, quale fa fare il prefato magnifico Meser Antonio. . . . L. XXX."

10. Franceschini, 1998, 147, discusses the painters' fees in relation to other Ferrarese artists of the period.

11. A reconstruction of the apse of S. Andrea is provided by Giovanni Fortini, "La chiesa di Sant'Andrea e il polittico Costabili," in Ciammitti, 37-53. On the church and its decorations, see Guarini, vol. 2, 361-74; Cesare Barotti, Pitture e scolture che si trovano nelle chiese, luoghi pubblici, e sobborghi della città di Ferrara (Ferrara: Giuseppe Rinaldi, 1770), 173-77; Scalabrini, 300-308; Carlo Brisighella, Descrizione delle pitture e sculture della città di Ferrara (ca. 1704), ed. Maria Angela Novelli (Ferrara: Spazio Libri, 1991), 472-81; Amalia Mezzetti and Emanuele Mattaliano, Indice ragionato delle "Vite de' pittori e scultor ferraresi" di Gerolamo Baruffaldi (Ferrara: Cassa di Risparmio di Ferrara, 1980), vol. 2, 20-23; and Thomas Tuohy, Herculean Ferrara: Ercole d'Este, 1471-1505, and the Invention of a Ducal Capital (Cambridge: Cambridge University Press, 1996), 367-68. The patron's chapel rites are outlined in his testament, for which see Pattanaro, 136-41, app.

12. Charles Dempsey, "Donatello's Spiritelli," in "Ars naturam adiuvans": Festschrift für Matthias Winner, ed. Victoria V. Flemming and Sebastian Schütze (Mainz: Philipp von Zabern, 1996), 50-61, defines spiritelli (spirits: celestial, infernal, or essences of pure sensations) in the context of Renaissance art and literature.

13. Conventionally, Isaiah's prophecy appears with recourse to 7:14: "Ecce virgo concipiet, et pariet filium" (Behold a virgin shall conceive, and bear a son). Latin text from Biblia sacra juxta Vulgatam Versionem; English translation from the Rheims-Douay Holy Bible.

14. Henriette Mendelsohn, Das Werk der Dossi (Munich: Georg Müller and Eugen Rentsch, 1914), 104-7 (1532-33); Roberto Longhi, "Precisioni nelle gallerie italiane: Regia Galleria Borghese; Un problema di Cinquecento ferrarese (Dosso Giovane)," Vita Artistica 2 (1927): 31-35 (early 1520s); Edoardo Arslan, "Una Natività di Dosso Dossi," Commentari 8 (1957): 261 (ca. 1522); Amalia Mezzetti, Il Dosso e Battista ferraresi (Milan: Silvana, 1965), 84-85 (ca. 1530); Felton Gibbons, Dosso and Battista Dossi: Court Painters at Ferrara (Princeton: Princeton University Press, 1968), 173-74 (ca. 1530). Gibbons drew attention to Vasari's chronology of the polyptych but dismissed it on the basis of his own stylistic arguments.

During the 17th and 18th centuries Emilian scholars believed that the Ferrarese painter Girolamo da Carpi (ca. 1501-1556) also contributed to the Costabili polyptych, thereby underscoring the distinctly Ferrarese character of the work; Francesco Scannelli, Il microcosmo della pittura (Cesena: Neri, 1657; reprint, Bologna: Nuova Alfa, 1989), 316; Brisighella (as in n. 11), 473; and Barotti (as in $\mathrm{n}$. 11), 174-75. The documents discovered by Franceschin exclude the role of Girolamo da Carpi, sometimes suggested in modern scholarship as well.

15. Pattanaro, 140: "Item lassa per ragione de legato e per el presente suo testamento ordina vole e dispone che tuti li soi pani del doso siano per li infrascripti soi heredi dati e donati ala sachristia de sancto Andrea per fare aparamenti al suo altare grande dove e la soa palla." Costabili's 1527 testamen annulled his previous one, cited as having been drawn up on Dec. 17, 1523 but which has yet to be discovered. Based on this evidence, Fioravanti Baraldi, $180-81$, has dated Dosso's intervention to 1523 and Garofalo's to 1527 whereas Ballarin, vol. 1, 90-91, 336-37, dates the altarpiece to about 1523-24. Ballarin first published his chronology of Dosso's works in Le siècle de Titien L'âge d'or de la peinture à Venise, exh. cat., Grand Palais, Paris, 1993, 402-22.

A clarification is in order regarding Pattanaro's reading of the expression "pani del doso" from the passage in Costabili's testament cited above. The author mistakenly inferred "pani del doso" to be cloth or fabrics decorated by the painter Dosso Dossi that were to be inventoried and donated to the sacristy of S. Andrea one month after Costabili's death, according to the patron's testament; Pattanaro, 132, 136 n. 28. However, panni del dosso (Latin: panni a dorso) is an expression found in countless Ferrarese inventories from the 14th through the 16th centuries that denotes fabrics or garments that one wears (indossare). Furthermore, I have discovered the inventory (in fragments) of garments in question, dated Aug. 1527 and entitled "Hec est pars inventarii [ ] hereditatis spectabilis domini Antonii C[ ]," Curia Arcivescovile, Ferrara, Archivio Storico Diocesano (hereafter ASD), Fondo S. Andrea, 7/L, vol. 19, fols. 201-3. The inventory appropriately lists all of the "panni del dosso," that is, costly garments worn on various occasions, that Antonio Costabili donated to the church of S. Andrea. Among the numerous items, the following two donations appear in sequence on 202: "Uno pare di manege de veluto negro fodrà de dossi. / Uno pare de manege de raso fodrà de volpe" (A pair of black velvet sleeves lined with fur. / A pair of silk sleeves lined with fox). In this instance, the expression "fodrà de dossi" refers to fur taken from the back of an animal, such as a fox (volpe), and used to line cloth. The inventory makes no reference to the artist Dosso Dossi. See Marcella Marighella, Un libro di spese di Leonora d'Este 1578-1581 (Ferrara: Accademia delle Scienze di Ferrara, 1996), 56 , and esp. 131 of the glossary, where the author defines dossi as follows: "pelli della schiena usate come fodera, di pelliccia" (fur from the back [of an animal] used as lining, for a fur garment).

16. Ballarin, vol. 1, 89-91. Documents for Dosso's Modena altarpiece are published in Daniele Benati, Francesco Bianchi Ferrari e la pittura a Modena fra '4 $e$ '500, register of documents by Orianna Baracchi (Modena: Artioli, 1990), 176-77; Carlo Giovannini, "Nuovi documenti sul Dosso," Prospettiva, no. 68 (1992): 57-60; and idem, "Notizie inediti sull'altare di S. Sebastiano e sul presepio del Begarelli nel Duomo di Modena," in Il Duomo e la torre di Modena: Nuovi documenti e ricerche, ed. Orianna Baracchi and Carlo Giovannini (Modena: Aedes Muratoriana, 1988), 207-26. For Garofalo's altarpiece, see Fioravanti Baraldi, 169-71.

17. Roberto Longhi, Officina ferrarese (1934), in Le opere complete da Roberto Longhi (Florence: Sansoni, 1956), vol. 5, 88. Longhi also attributed to Dosso the figure of Saint Andrew, yet I feel that this saint is by Garofalo and relates to the artist's treatment of the saintly body in his Suxena Altarpiece.

18. Beginning with Mezzetti (as in n. 14), 84, art historians, namely Ballarin, vol. 1, 90, and Humfrey and Lucco, 23, have frequently assigned the figure to the hand of Dosso. I agree with Pattanaro, $134 \mathrm{n}$. 17, who sees the work as characteristic of Garofalo, especially in comparison with the treatment of impasto in the cloud of angels in the central panel.

19. Humfrey and Lucco, esp. 30 n. 17, where they briefly mention Vasari's chronology. The authors' observations on the Costabili polyptych have been incorporated into the catalogue entry by Humfrey in Bayer, 98-103. See also Peter Humfrey, "Dosso Dossi et la peinture de retables," Revue de l'Art 119 (1998): 9-20

20. Humfrey, in Bayer, 102. Whether Dosso visited Rome prior to 1513, or at any point in his career, continues to be a vexing question for art historians. While it is clear that Dosso assimilated the art of Rome in his own works, what is important to this inquiry is the calculated, self-conscious difference of Dosso's manner from artists such as Raphael. A look at the question from the point of view of historiography provides further insight into this observation. Lanzi, vol. 3, 155, celebrated the unexampled style of Dosso and his brother Battista Dossi, claiming, "Formaron così 'un lor propio carattere,' ma in gener diverso. Dosso riuscì maravigliosamente nelle figure; Giovanni Batista forse men che mezzanamente" (They fashioned their very own artistic character, but in different ways. Dosso succeeded wonderfully in making figures, whereas Giovanni Battista achieved maybe less than average quality). Camillo Laderchi, La pittura ferrarese: Memorie (Ferrara: Abram Servadio, 1856), 69, emphasized the clear difference between the art of Raphael and Dosso, observing that the figures of Raphael are supple (svelte) and delicate (gentile), whereas those of Dosso are fleshier (carnoso) and more robust (robuste). Alternatively, Cesare Cittadella, Catalogo istorico de' pittori e scultori ferraresi e delle opere loro (Ferrara: Francesco Pomatelli, 1782-83), vol. 1, 137-38, preferred, as Francesco Scannelli had before him, to compare Dosso to Correggio, especially regarding their strength in coloring ("la forza del colorito").

21. Andrea de Marchi (as in n. 2), 158-61; Ciammitti, introduction, 9-26; Nicholas Penny, review of the exhibition Dosso Dossi: Pittore di Corte a Ferrara nel Rinascimento, Burlington Magazine 141 (1999): 253-54. Francis Haskell, "Mysterious Masterpieces," New York Review of Books, Feb. 18, 1999, 43, voices skepticism over the completion of the polyptych by 1514 .

22. Vincenzo Gheroldi, "Techniche e strati," in Ciammitti, 75-112. For further technical analysis on Dosso's paintings, see idem, "Painting a Calce and Sprezzatura in the 1530s: A Technical Context for Dosso," in Ciammitti et al. 113-39; Andrea Rothe and Dawson W. Carr, "Poetry with Paint," in Bayer, 55-64; Jadranka Bentini, "Dosso's Works in the Galleria Estense, Modena, and the Pinacoteca Nazionale, Ferrara," in Bayer, 65-71, esp. 68-69; Anna Coliva, "Dosso's Works in the Galleria Borghese: New Documentary, Iconographical, and Technical Information," in Bayer, 72-80; Barbara H. Berrie, "A Note on the Imprimatura of Two of Dosso Dossi's Paintings," Journal of the American Institute for Conservation 33 (1994): 307-13; Barbara H. Berrie and Sarah L. Fisher, "A Technical Investigation of the Materials and Methods of Dosso Dossi," in Preprints, ICOM Committee for Conservation, ed. Janet Bridgland (Paris: ICOM Committee for Conservation, 1993), vol. 1, 70-74; and Allan Braham and Jill Dunkerton, "Fragments of a Ceiling Decoration by Dosso Dossi," National Gallery Technical Bulletin 5 (1981): 27-37. 
23. Erwin Panofsky, Perspective as Symbolic Form, trans. Christopher Wood (New York: Zone Books, 1991), 40-41: "But if perspective is not a factor of value, it is surely a factor of style. Indeed, it may even be characterized as (to extend Ernst Cassirer's felicitous term to the history of art) one of those 'symbolic forms' in which 'spiritual meaning is attached to a concrete, material sign and intrinsically given to this sign.' This is why it is essential to ask of artistic periods and regions not only whether they have perspective, but also which perspective they have.'

24. Ballarin, vol. 1, 314-15; and see the entry by Concetto Nicosia in Bentini (as in n. 4), 310.

25. Significantly, the Ferrarese historian Agostino Superbi understood that there was an equal division of labor between Dosso and Garofalo on the Costabili polyptych, as he notes in his Apparato de gli huomini illustri della città di Ferrara (Ferrara: Francesco Suzzi, 1620), 124: “... vedesi nella Patria nostra nella Chiesa de' Padri di S. Andrea l'Altare Maggiore la metà sua [Garofalo], e l'altra metà del Dosso" (. . . one sees [among the many works of Garofalo] an example in our city in the church of the fathers of S. Andrea at the high altar, which is half by Garofalo, the other half by Dosso).

26. Ballarin, vol. 1, 90-91, attributes the design of the central panel to Dosso, whereas Humfrey and Lucco, 25, argue the case for Garofalo. Andrea de Marchi (as in n. 2), 159-60, suggests that the structure of the drawing for nearly all the saints in the central panel is by Garofalo, with some of the surface paint later transformed by Dosso.

27. Gheroldi (as in n. 22), 103. The traces of pentimenti in the Costabili polyptych, some visible with the naked eye, are common in the practice of Dosso, for which see the essay concerning the artist's working methods by Rothe and Carr (as in n. 22).

28. Cittadella (as in n. 20), vol. 1, 141: "Questa Tavola a miei giorni ... fu più ingiuriata da chi si pretese di ristorarla, malamente lavandola, e scorticandola negli ombreggiamenti, che dal lungo tratto del tempo; con tutto ciò conserva in gran parte la sua bellezza" (This painting in my days was injured more by those who purported to restore it-cleaning it poorly and skinning it in the areas of shading - than by weathering over a long time. Despite all this it maintains in large part its beauty). Gheroldi (as in $\mathrm{n} .22$ ), 77-78, does take into careful consideration 19 th-century restorations.

29. Fioravanti Baraldi, 114-15.

30. Scannelli (as in n. 14), 316: "Nella Chiesa detta di S. Andrea de' Padri Agostiniani vi è la Tavola del Choro, dove si scopre la Beata Vergine col Christo Bambino, e varii Santi dalle parti, e la figura della Santissima Madre è così ben espressa con gratia, e decoro, che al certo non si può desiderare attitudine maggiormente maestosa, e per ogni parte compita, e degna. ... ed il tutto stà assai bene, ma la figura della $B$. Vergine viene in ogni tempo riconosciuta $d i$ più eccellente bellezza" (In the church of S. Andrea of the Augustinian father there is a painting in the choir, where one finds the Blessed Virgin with the Christ Child, and various saints in the panels; and the figure of the most Blessed Mother is so well expressed with grace and decorum that it is certain one cannot desire a character more majestic, and with every part perfected and worthy. ... The entire altarpiece is very well made, but the figure of the Blessed Virgin is recognized throughout time for its most excellent beauty) Guarini, 362, considered the polyptych one of the jewels of S. Andrea. Later copies of various parts of the polyptych are examined by Alessandra De Santis, "Le copie del polittico Costabili," in Ciammitti, 141-59.

31. Fioravanti Baraldi, 132-33.

32. Bentini, 135-37, inv. no. 143; Fioravanti Baraldi, 163-65. Adriano Franceschini, during the round-table discussion at the conference "L'età di Alfonso I e la pittura del Dosso" (Istituto di Studi Rinascimentali, Ferrara, Dec. 9-12, 1998), announced that he had discovered a document detailing Antonio Costabili's intervention between the Augustinian friars and Garofalo regarding the remuneration for the artist's decoration in the refectory of $\mathrm{S}$. Andrea. The document will be included in the forthcoming volume (pt. 3) of Franceschini's Artisti a Ferrara in età umanistica e rinascimentali: Testimonianze archivistiche, doc. 121.

33. Curia Archivescovile, Ferrara, ASD, Fondo S. Andrea, 5/D (Expense), n.p.; under expenses for Mar. 1524 (Expense mensis martii): “Adì 31 . . (u supra) al procuratore per dare ali depintori dela capela del Crucifixo et della Madona, Maiestro Thomaso et Maiestro Benvenudo.... lire 6, soldi dinari —. / Adì ultimo ... (ut supra) al procuratore lire tre per dare ali dipintori suprascripti. . . . lire 3 , soldi 5 , dinari —_."

34. The question of Dosso's place of birth and education is still debated in the scholarship. Franceschini, 1995, 112-13, 1998, 144-45, has conducted archival research into Dosso's family name, Lutero/i, suggesting that he came from Tramuschio in the small city-state of Mirandola, which borders the duchy of Ferrara and the state of Mantua. For a study arguing the possible Modenese origins of Dosso, see Orianna Baracchi, "I Luteri a Modena," Atti e Memorie della Deputazione di Storia Patria per le Antiche Provincie Modenesi 19 (1997): 93-119. However, Carlo Giovannini, 1992 (as in n. 16) claims that Dosso originated from the southern part of the state of Mantua, in the village of Dosso Scaffa (now known as S. Giovanni del Dosso), near Mirandola, Quistello, and Revere.

35. Franceschini, 1995, 116 n. 17, 1998, 150-51 n. 18; 1997, doc. 1042, has published a document dated Mar. 14,1514, indicating that Dosso was on the payroll of the duke of Ferrara, Alfonso I, and being housed in the Este castle. This is the earliest reference pertaining to Dosso's work for the Este of Ferrara.
36. Isabella Fedozzi has convincingly identified the sitter in Dosso's portrait as Antonio Costabili, in "Antonio Costabili: Un ritratto; Cenni sulla committenza d'arte a Ferrara nel primo Cinquecento," in Ciammitti, 55-73. The author also connects the sitter to the figure of a man in Garofalo's Allegory of the Crucifixion, executed for the refectory of S. Andrea. Ballarin, vol. 1, 313, first attributed the portrait to Dosso, dating it to about 1519. Mauro Lucco dates the work to about 1520 but questions the attribution to Dosso in his entry for the recent exhibition catalogue, in Bayer, 238-39. I am very grateful to Andrea Bayer for helping me obtain this photograph.

37. An 18th-century(?) transcription of a document from 1388 reveals the dedication to the Virgin of the Costabili chapel at the high altar: Curia Archivescovile, Ferrara, ASD, Fondo S. Andrea, Libro 20 (Notizie diverse di testamenti), fol. 64, no. 116: "Calindreso Costabili nel suo Testamento rogato [di] Francesco da Rovigo 17 giugno 1388 ... Lascia al Convento Lire 20 marchesine con obligo d'una messa continua al suo Altare di S. Maria appreso l'altare grande."

38. Pattanaro, 136: "Item prima che venendo el chaxo overo tempo dela soa morte lanima sua racomanda a dio el quale priega che el se voglia dignare de alogare la dicta soa anima nel Sancto paradiso et el suo corpo vole che sia sepelido nela giexia de sancto Andrea nela sepultura che se habia a fare e cusi comanda che la se habia a fare fare per li infrascripti soi heredi alo altare grande dela dicta giexia nela quale sepultura el vole chel sia spexo per li soi heredi ducati centocinquanta e non mancho e nela quale sepultura el vole e comanda che se habia a metere tute le osse de tuti li soi morti zoe de suo padre de sua madre de suoi fratelli e de soi nepoti acompagnato dali frati de Sancto Andrea, de Sancto Spirito de Sancto domenego, di Anzoli, e di Servi, e segondo che parera ali suoi heredi infrascripti."

39. On Alfonso I d'Este, see Antonio Capelli, ed., "Vita di Alfonso I d'Este Duca di Ferrara, Modena e Reggio scritta da Bonaventura Pistofilo da Pontremoli Segretario di Esso Duca," Atti e Memorie delle RR. Deputazioni di Storia Patria per le Provincie Modenesi e Parmensi 3 (1865): 448-56; Paolo Giovio, Liber de vita et rebus gestis Alfonsi Atestini Ferrariae Principis (Florence: Lorenzo Torrentino, 1551), translated into Italian by Giovanbattista Gelli, La vita di Alfonso da Este Duca di Ferrara di Mons. Paolo Giovio Vescovo di Nocera (Venice: Giovanni Battista and Giovanni Bernardo Sessa, 1597); Giovanbattista Giraldi, De Ferraria et Atestinis Principibus commentariolum (Ferrara: Francesco Rubeo, 1556), translated into Italian by Lodovico Domenichi, Commentario delle cose di Ferrara, et de Principi da Este (Florence: Lorenzo Torrentino, 1556), 138-89; Gasparo Sardi, Libro delle historie ferraresi, ed. Agostino Faustini (Ferrara: Giuseppe Ginori, 1646), vol. 1, 203-30; Ludovico Antonio Muratori, Delle antichità estensi (Modena: Stamperia Ducale, 1740), pt. 2, 279-363; and Antonio Frizzi, Memorie per la storia di Ferrara, ed. Camillo Laderchi, 2d ed. (Ferrara: Abram Servadio, 1848), vol. 4, 219-326.

An essential survey on Julius II's political campaigns remains that of Ludwig Pastor, The History of the Popes (London: Kegan Paul, Trench, Trübner, 1901), vol. 6, 185-454. My account of the friction between Ferrara and Rome also draws on Felix Gilbert, The Pope, His Banker, and Venice (Cambridge: Cambridge University Press, 1980), 88ff.; Ingrid Rowland, "A Summer Outing in 1510: Religion and Economics in the Papal War with Ferrara," Viator 18 (1987): 347-59; and Christine Shaw, Julius II: The Warrior Pope (Oxford: Blackwell, 1993).

40. Francesco Guicciardini did not fail to acknowledge Alfonso's decisive victory in his Storia d'Italia, ed. Silvana Seidel Menchi (Turin: Einaudi, 1971), vol. 2, 806-12. A modern historical perspective of the battle is provided by Robert Finlay, "Venice, the Po Expedition and the End of the League of Cambrai, 1509-10," Studies in Modern European History and Culture 2 (1976): 37-72.

41. Pope Julius II, “... è volontà di Dio di castigar el ducha di Ferrara e liberar Italia de' man de Francesi”; quoted in Pastor (as in n. 39), 322, n. Julius made this declaration on May 14,1510

42. Richard Brown, "The Politics of Magnificence in Ferrara 1450-1505: A Study in the Socio-Political Implications of Renaissance Spectacle," Ph.D. diss., University of Edinburgh, 1980, explores the importance of ritual celebration in Ferrara and its impact on civic and religious life.

43. The Ferrarese chronicle of Paolo Zerbinati, long recognized for its accuracy, was transcribed in the 17 th century by Giovanni Maria Zerbinati, under whose name it is published; Zerbinati, 100: “[1510] La scomunica di Ferrara si è intesa chiaramente questo dì 14 settembre in Ferrara, non si è detto messa alcuna nella città, et non so come la stia, per non l'havere intesa né letta per non essere stata portata a Ferrara, et nota che sino il dì sopradetto li preti di vescoato non volessero dire messa né vespero, né sonarlo, ma dapoi dissero messa e gli altri offitii per tutto il dì 13 detto, ma hoggi ogni chiesa ha lasciato di offitiare et non sonano altro che l'Ave Maria la mattina et da mezzo dì e la sera, né so altro di detta scomunica se non che siamo privi di messe e divini offitii e di confessione e di comunione eccetto che in articulo mortis et non si sepelisse morti in chiesa né in sacrato e li pretti e fratti non vano a morti e la più parte delli frati si sono partiti da Ferrara, pochi ne sono rimasti per monasterio, cosa grande e tremenda, il signor Iddio per sua pietà e misericordia non ci abbandoni" (The excommunication [read "interdict"; $c f$. n. 44 below]) of Ferrara manifested itself clearly this day, the 14th of September in Ferrara; no mass was said in the city, and I do not know how this happened, as the news was neither heard nor read because it was not brought to Ferrara. Note that even up to the aforementioned day the priests of the episcopate at first were not willing to say mass, or vespers, or sing, but 
afterward they performed mass and other offices for the whole day of the 13th However, today every church abandoned performing offices and singin anything except the Ave Maria in the morning, afternoon, and evening. I do not know anything else about the excommunication other than that we are deprived of mass, divine offices, confession, communion, except for in articulo mortis, yet the dead are not buried in church or on sacred ground. The priests and friars do not attend to the dead and the majority of friars have left Ferrara, few have remained in the monastery. What a terrible and awful thing; I hope that the Lord with his piety and mercy will not abandon us).

44. Confirmation reached Ferrara four days later when an elated Zerbinati quoted the papal bull in his chronicle; Zerbinati, 132: “[17 March 1513] . 'Interdictum ecclesiasticum et omnes censuras quibus felicis recordationis Julii II, predecessor noster, te [Alfonso I d'Este] et civitatem ferrariensem et loca dominii tui, subdicta inodavit, te et civitatem ferrariensem, et omnes subdictos tuos, per menses duos a presentatione huius nostri, et ultra ad beneplacitum nostrum suspendimus, relaxamus teque absolvimus etc. Datum Romae ante incoronationem nostram die 13 Martii 1513.'"

45. Costabili's restoration campaign is discussed by Alfonso Maresti, Cronologia et istoria de capi, e giudici de Savii della Città di Ferrara (Ferrara: Stampa Camerale, 1683), 65: "Nelle Guerre, che hebbe il Serenissimo Duca Alfonso Primo restò il Costabili Vice Duca in Ferrara, nella qual carica si fece grandissimi onori. Finite le Guerre fece ristaurare gran quantità di edificii, e rifare tutti gli Ponti così sopra il Pò vicino alla Città, come per tutto lo Stato, quali per le passate Guerre erano stati distrutti. Fece riedificare il Palazzo dell Ragione, vedendosi in esso sino al giorno d'oggi la sua Arme" (During the wars that the most serene Duke Alfonso I waged, Costabili remained as vice duca in Ferrara, in which capacity he brought upon himself such great honor At the end of the wars, he had restored a great quantity of buildings, and rebuilt all the bridges over the Po River near the city, as well as throughout all the state, which had been destroyed during the battles. He had reconstructed the Palazzo della Ragione, which one can even see today bearing his coat of arms). A marble plaque that was once displayed in the Palazzo della Ragione commemorated Costabili's acts; see Guarini, vol. 1, 200. On Antonio Costabili I consulted the following: Celio Calcagnini, In funere Antonii Constabilis, oratio, in Opera aliquot (Basel: Froben, 1544), 512-15; Guarini, vol. 2, 364-68; Alfonso Maresti, Teatro geneologico et istorico dell'antiche, et illustri famiglie di Ferrara (Ferrara: Stampa Camerale, 1681), 179; DBI, vol. 30 (1984), s.v. "Costabili, Antonio," 257-60; and Fedozzi (as in n. 36)

46. The date of Costabili's appointment to office, Apr. 18, 1506, has caused confusion in recent literature, yet it is confirmed by a number of contemporary sources, including Zerbinati, 60: “[1506] Adì detto [Apr. 18] l'illustrissimo signor duca ha finito di dare li suoi offitti et ha fatto messer Antonio Costabili giudice de Savi, in loco del Strozzi, il quale messer Antonio è gentilhomo e cavaliero a speron d'oro e conte e secretto consiliero ducale" (On the aforementioned day [Apr. 18] the illustrious duke finished making official appointments and named Antonio Costabili giudice de Savi, in place of [Tito] Strozzi. Sir Antonio is a gentleman and knight of the Golden Spur, count, and private counselor of the duke).

47. Zerbinati, 103. The chronicler describes Costabili's meeting with the papal ambassador as occurring in June 1510.

48. Costabili's banquet is described in a letter dated Apr. 2, 1513, and addressed to Isabella d'Este of Mantua from her correspondent in Ferrara, Bernardino Prosperi; see Alessandro Luzio, "Isabella d'Este e i Borgia," Archivio Storico Lombardo 42 (1915): 165-67; Michele Catalano, Lucrezia Borgia duchessa di Ferrara, con nuovi documenti: Note critiche e un ritratto inedito (Ferrara:

A. Taddei et Figli, 1920), 34; and idem, Vita di Ludovico Ariosto ricostruita su nuovi documenti (Geneva: Leo S. Olschki, 1930), vol. 1, 579.

49. Fini refers to Antonio Costabili as pater patriae (father of the country) in a poem dedicated to the Ferrarese poet Lodovico Bigo Pittorio, which is published in Silvio Pasquazi, Poeti Estensi del Rinascimento (Florence: Felice Le Monnier, 1966), 89-91.

50. Sociological studies into court culture include Werner Gundersheimer Ferrara: The Style of a Renaissance Despotism (Princeton: Princeton University Press, 1973); and Nobert Elias, The Court Society, trans. Edmund Jephcott (Oxford: Basil Blackwell, 1983). See also the essays in Roberta Iotti, ed., La corte di Ferrara (Modena: Il Bulino, 1997). It should be noted that Antonio Costabili frequently used the municipal registers and accounts for his personal transactions.

51. John Oswalt, The Book of Isaiah, Chapters 1-39 (Grand Rapids, Mich.: William B. Eerdmans, 1986), 240-48. On the biblical concept of peace, see The Anchor Bible Dictionary (New York: Doubleday, 1992), vol. 5, s.v. "Peace," 206-12.

52. Saint Augustine, Quaestiones in Heptateuchum, 6.10, defines bellum justum as follows: "Iusta autem bella ea definiri solent quae ulciscuntur iniurias, qua gens vel civitas, quae bello petenda est, vel vindicare neglexerit quod a suis inprobe factum est vel reddere quod per iniurias ablatum est. Sed etiam hoc genus belli sine dubitatione iustum est, quod deus imperat...." (The just wars, after the common definition, are those which avenge the injuries, when people or a state neglect to punish the wrongs committed by its citizens or to return those things unjustly taken. Without any doubt that war commanded by God is also just. . . .); Latin from Corpus Christianorum: Series Latina (Turnhout: Brepols, 1958), vol. 33, 319; trans. José A. Fernández, "Erasmus on the Jus War," Journal of the History of Ideas 34 (1973): $220 \mathrm{n}$. 44. See further Rober H.W. Regout, La doctrine de la guerre juste de Saint Augustin à nos jours (Paris: A.
Pedone, 1934), 1-130; Dictionnaire de théologie catholique (Paris: Librairie Letouzey et Ainé, 1947), vol. 6, s.v. "Guerre," cols. 1899-962; and Roland H. Bainton, Christian Attitudes toward War and Peace: A Historical Survey and Critical Re-evaluation (New York: Abingdon Press, 1960).

53. For a discussion of the religious and artistic exchange in early 16thcentury Ferrara that takes a different view from my own study, see Anna Maria Fioravanti Baraldi, "Vita artistica e dibattiti religioso a Ferrara nella prima metà del cinquecento," in La pittura in Emilia $e$ in Romagna: Cinquecento, un romanzo polifonico tra Riforma e Controriforma (Milan: Electa, 1995), 105-25; and idem, "Ludovico Pittorio e la cultura figurativa a Ferrara nel primo cinquecento," in Alla corte degli Estensi: Filosofia, arte e cultura a Ferrara nei secoli XV e XVI, ed. Marco Bertozzi (Ferrara: Università degli Studi, 1994), 217-46.

54. Gerolamo Baruffaldi, Dissertatio, de poetis ferrariensibus (Ferrara: Bernardini Pomatelli, 1698), 36; Ferrante Borsetti, Historia almi ferrariae gymnasii (Ferrara: Bernardini Pomatelli, 1735), vol. 2, 332; Giammaria Mazzuchelli, Gli scrittori d'Italia cioè notizie storiche, e critiche intorno alle vite, e agli scritti dei letterati italiani (Brescia: Giambatista Bossoni, 1762), vol. 2, 1922-23; DBI, vol. 13 (1971), s.v. "Bovio, Francesco Bernardino," 550. Bovio composed a number of poems in praise of Alfonso I d'Este's military triumphs.

55. The poem is in Bovio's autograph manuscript: Francisci Bernardini Bovii Ferrariensis, Carmina (Elegiae, Epigrammata, Tumuli), BAF ms Cl.I.69, fols. 123v-124r: "Hic mos militibus, nequeunt tolerare quietem, / Sed semper motus, unde lucrentur, amant. / Nos cupimus pacem, pacis Deus, o, bene verte, / Pacemque iam stabilem munere redde tuo. / Quam non ipse potest mundus dare, tu Deus alme / Corporis atque animae nos, rogo, pace fove."

56. Desiderius Erasmus, Julius Excluded from Heaven: A Dialogue, trans. Michael J. Heath, in Collected Works of Erasmus, ed. A.H.T. Levi (Toronto: Toronto University Press, 1986), vol. 27, 155-97; Latin text, Erasmi opuscula, ed. Wallace K. Ferguson (The Hague: Martinus Nijhoff, 1933), 65-125. In the dialogue, Erasmus has the character "Julius" pitifully and ironically attempt to defend his unjust aggressions toward Alfonso I.

57. Oswalt (as in n. 51), 240-48; John F.A. Sawyer, The Fifth Gospel: Isaiah in the History of Christianity (Cambridge: Cambridge University Press, 1996).

58. For Erasmus's theological methodology and its impact, see Marjorie O'Rourke Boyle, Erasmus on Language and Method in Theology (Toronto: University of Toronto Press, 1977); Silvana Seidel Menchi, Erasmo in Italia 1520-1580 (Turin: Bollati Boringhieri, 1987).

59. Desiderius Erasmus, A Complaint of Peace Spurmed and Rejected by the Whole World, trans. Betty Radice, in Levi (as in n. 56), 299; Desiderii Erasmii Roterodami: Opera Omnia (Amsterdam: North Holland, 1977), vol. 4, pt. 2, 68-70: "Universam eius vitam contemplare: quid aliud est, quam concordiae mutuique amoris doctrina? Quid aliud inculcant eius praecepta, quid parabolae, nisi pacem, nisi charitatem mutuam? Egregius ille vates Esaias, cum caelesti afflatus spiritu Christum illum rerum omnium conciliatorem venturum annunciaret, num satrapam pollicetur, num urbium eversorem, num bellatorem, num triumphatorem? Nequaquam. Quid igitur? Principem pacis; siquidem cum omnium optimum principem intellegi vellet, ab ea re denotavit, quam omnium optimam iudicasset." A useful study of Erasmus's text is Roland H. Bainton, "The Querela Pacis of Erasmus, Classical and Christian Sources," Archiv für Reformationsgeschichte 42 (1951): 32-48.

60. Leon Battista Alberti, On Painting and Sculpture: The Latin Texts of "De Pictura" and "De Statua," ed. and trans. Cecil Grayson (London: Phaidon, 1972), 95ff. For a definition of inventio in Renaissance art theory, see Martin Kemp, 'From 'Mimesis' to 'Fantasia': The Quattrocento Vocabulary of Creation, Inspiration and Genius in the Visual Arts," Viator 8 (1977): 347-98.

61. For a history of S. Andrea, see the references cited in n. 11. Guarini, vol. 2, 362, records that Paolo Costabili, Antonio's grandfather, who also served as giudice of the Dodici Savi, provided funds to help construct the cloister of $\mathrm{S}$. Andrea: “. . essendo Giudice de' Savi Paolo Costabili vi si edificò un'amplissimo Claustro sostenuto da numerosa quantità di collone de marmo ben regolate" (Paolo Costabili, as giudice of the [Dodici] Savi, constructed there a spacious cloister supported with a large quantity of well-ordered marble columns). The various theological centers in Ferrara are examined by Domenico Dal Nero, "L'Insegnamento della teologia in Europa e a Ferrara," in La rinascita del sapere: Libri e maestri dello studio ferrarese, ed. Patrizia Castelli (Venice: Marsilio, 1991), 246-63. On the related development of humanist theology in the Renaissance, see Salvatore I. Camporeale, "Renaissance Humanism and the Origins of Humanist Theology," in Humanity and Divinity in Renaissance and Reformation: Essays in Honor of Charles Trinkhaus, eds. John W. O'Malley, Thomas M. Izbicki, and Gerald Christianson (Leiden: E. J. Brill, 1993), 101-24; Charles Trinkhaus, "The Religious Thought of the Italian Humanists, and the Reformers: Anticipation or Autonomy?" in The Pursuit of Holiness in Late Medieval and Renaissance Religion (Leiden: E. J. Brill, 1974), 339-66.

62. On Andrea Baura's life and work, see DBI, vol. 7 (1965), s.v. "Baura, Andrea," 296-97; and Antonio Samaritani, "Contributo documentario per un profilo spirituale religioso di Lucrezia Borgia nella Ferrara degli aa. 15021519," Analecta Tertii Ordinis Regularis Sancti Francesci 14 (1981): 957-1007, esp. $975-90$

63. Interestingly, Baura was condemned for expressing "heretical" (or Lutheran) views in a public oration he delivered in Venice in 1520. In response to increasing papal pressure and the threat of censure, Baura published a text in 1523 denouncing Luther's theology and stressing papal primacy with recourse to the authority of Saint Peter: Apostolicae potestatis defensio ... In 
Lutherum, for which see Antonio Samaritani, "La defensio di Pietro Scazzano in favore di Andrea Baura contro Lorenzo Castrofranco (a. 1520) ai prodrom della polemica antiluterana in Italia," Analecta Augustiniana 47 (1984): 5-42; Adriano Prosperi, "Le istituzioni ecclesiastiche e le idee religiose," in I rinascimento nelle corti padane: Società e cultura, ed. Paolo Rossi (Bari: De Donato, 1977), 125-62, esp. 149; and Fedozzi (as in n. 36), 58-60.

64. Andrea Baura, Exposition ingeniosa et accomodata a nostri tempi del XIV, XV et XVII Psalmo (Ferrara: Ioannes Maciochius Bondenus, 1513), 18r-19r: "Diligam te domine: Signore io vo pensando che debio fare per non essere ingrato ala tua maiesta di tanta gratia quanta mi hai concessa liberandomi de tante calamita, et non scio che mi operare perho che ogni mia operatione è nulla apreso la infinita maiesta tua, scio che non hai bisogno dele operatione mie. . . Fortitudo mea: La mia fortezza nela quale mi salvaro se mai più sero dal inimici mei tribulata. Et se tu serai forteza mia chi sera che persuma in alcun modo offendermi[?] Altre volte quando non te amava mi confidava nele forteze terrene, ne le arme, ne i soldati, et nele forte mure, et repari, quali existimava inexpugnabili, ma me inganava, perchè non è forteza dove non sei tu."

65. It was the philological approach of humanist exegesis, which treated Scripture as a text-one governed by formal lexical and syntactic rules-that brought biblical scholarship into the discipline of history; in addition to the references cited in n. 61 above, see Debora Kuller Shuger, The Renaissance Bible: Scholarship, Sacrifice, and Subjectivity (Berkeley: University of California Press, 1994), esp. 1-53.

66. Art historians have tended to see the format of the frame as conservative and obsolescent without considering its potential symbolism; Gibbons (as in n. 14), 173; Humfrey, in Bayer, 98. On the later history and restoration of the frame, see Barbara Ghelfi, "Le cornici del polittico Costabili," in Ciammitti, $113-40$

67. Deborah Howard, “Giorgione's Tempesta and Titian's Assunta in the Context of the Cambrai Wars," Art History 8 (1985): 271-89. For further interpretations and references concerning Titian's The Assumption of the Virgin, see Harold Wethey, The Paintings of Titian, vol. 1, The Religious Paintings (London: Phaidon, 1969), 74-76; and Peter Humfrey, The Altarpiece in Renaissance Venice (New Haven: Yale University Press, 1993), 301-4, 357.

68. Howard (as in n. 67), 286

69. Humfrey, in Bayer, 100, claims, "The image of the resurrected Christ in the apex was a natural, even necessary inclusion in a chapel where the patron-as he specified in his will of 1527-intended to be buried; it expressed his hope for his own resurrection through the merits of his Savior." For secular images glorifying Alfonso's victory at the Battle of Ravenna and his policy of "peace through strength," see Wendy Steadman Sheard, "Antonio Lombardo's Reliefs for Alfonso I d'Este's Studio di Marmi: Their Significance and Impact on Titian," Studies in the History of Art 45 (1993): 315-57, esp. 329 and Douglas Lewis, "The Washington Relief of Peace and Its Pendant," in Collaboration in Italian Renaissance Art, ed. Wendy Steadman Sheard and John Paoletti (New Haven: Yale University Press, 1978), 233-44.

70. Egidio's oration is discussed by John O'Malley, Praise and Blame in Renaissance Rome: Rhetoric, Doctrine, and Reform in the Sacred Orators of the Papal Court, c. 1450-1521 (Durham, N.C.: Duke University Press, 1979), 230.

71. John O'Malley, Giles of Viterbo on Church and Reform: A Study in Renaissance Thought (Leiden: E. J. Brill, 1968); idem, "Giles of Viterbo: A Reformer's Thought on Renaissance Rome," Renaissance Quarterly 20 (1967): 1-11; and Francis X. Martin, Friar, Reformer, and Renaissance Scholar: Life and Work of Giles of Viterbo 1469-1532 (Villanova: Augustinian Press, 1992).

72. Eugene F. Rice, Saint Jerome in the Renaissance (Baltimore: Johns Hopkins University Press, 1985)

73. An insightful examination of art as a "superintendency of knowledge" is offered by Robert Williams, Art, Theory, and Culture in Sixteenth-Century Italy: From Techne to Metatechne (Cambridge: Cambridge University Press, 1997), esp $1-28$.

74. Saint Ambrose, On the Death of Theodosius, trans. Roy J. Deferrari, in Funeral Orations by Saint Gregory Nazianzen and Saint Ambrose (New York: Fathers of the Church, 1953), 331, Sancti Ambrosi opera, in Corpus Scriptorum Ecclesiastico rum Latinorum, ed. Otto Faller, vol. 73, pt. 7 (Vienna: Hoelder, Pichler Tempsky, 1955), 399: “ 'Portavit iugum grave,' quando subiit pietatis exilium, quando infusis Romano imperio barbaris suscepit imperium. 'Portavit iugum grave,' ut tyrannos Romano imperio dimoveret. Sed quia hic in labore, ibi in requie." On Saint Ambrose and the theme of war, see François Heim, "Les figures du prince idéal au IVe siècle: Du type au modèle," in Figures de l'Ancien Testament chez les Pères (Strasbourg: Centre d'Analyse et de Documentation Patristiques, 1989), 277-301; and idem, "Le thème de la 'victoire sans combat' chez Ambroise," in Ambroise de Milan, XVIe centenaire: Son éléction épiscopale (Paris: Etudes Augustiniennes, 1974), 267-81. A useful biography of Ambrose is in Neil B. McLynn, Ambrose of Milan: Church and Court in a Christian Capital (Berkeley: University of California Press, 1994).

75. Saint Ambrose (as in n. 74), 307-8, Corpus Scriptorum (as in n. 74), 372 "Sed non sunt destituti, quos pietatis suae reliquit heredes, non sunt destituti, quibus Christi adquisivit gratiam et exercitus fidem, cui documento fuit deum favere pietati ultoremque esse perfidiae."

76. Saint Augustine, 4:15: "Iniquitas enim eorum cum quibus iusta bella gesta sunt regnum adiuvit ut cresceret, quod utique parvum esset, si quies et iustitia finitimorum contra se bellum geri nulla provocaret iniuria. ..."
77. The "Adages" of Erasmus: A Study with Translations, ed. Margaret Mann Phillips (Cambridge: Cambridge University Press, 1964), 308-57; for the Latin text with an insightful commentary, see Silvana Seidel Menchi, ed., Erasmo da Rotterdam, Adagia: Sei saggi politici in forma di proverbi (Turin: Einaudi, 1980), 196-285. See further Fernández (as in n. 52), 209-26; John R. Hale, "Sixteenth-Century Explanations of War and Violence," Past and Present 51 (1971): 3-26.

78. Valla's politics are expressed in his De falso credita et ementita Constantini donatione declamatio, for which I consulted The Treatise of Lorenzo Valla on the Donation of Constantine, trans. Christopher B. Coleman (1922; reprint, Toronto: University of Toronto Press, 1993), 163-69. An indispensable study of Valla's scholarship is Salvatore I. Camporeale, Lorenzo Valla: Umanesimo e teologia (Florence: Nella Sede dell'Istituto, 1972).

79. Heim, 1989 (as in n. 74), 292-93.

80. Saint Augustine, trans. William Chase Greene, 1969, 19.12: "Quando quidem et ipsi qui bella volunt nihil aliud quam vincere volunt, ad gloriosam ergo pacem bellando cupiunt pervenire." Herbert Deane provides an informative analysis of Augustine's concepts of peace and war in The Political and Social Ideas of St. Augustine (New York: Columbia University Press, 1963), 99-103, 154-71.

81. Ernst H. Kantorowicz, "The 'Kings Advent' and the Enigmatic Panels in the Doors of Santa Sabina," Art Bulletin 26 (1944): 207-31, esp. 209.

82. The monument was installed on the feast of the Ascension, June 2, 1451, and attached to the Palazzo Municipale. It had strong military and triumphal associations complemented by an inscription which, as Charles Rosenberg states, "chose to emphasize Niccolò's pacific rather than bellicose accomplishments, focusing on his achievement of one of the most important goals of the ideal Christian prince, the pursuit of peace"; Rosenberg, The Este Monuments and Urban Development in Renaissance Ferrara (Cambridge: Cambridge University Press, 1997), 50-82, esp. 74.

83. Samson's act is described in Judges 14:5-8. The early reception and symbolism of the coin is discussed by Rupert Shepherd, "A Letter Concerning Coins in Sixteenth-Century Ferrara," Apollo 149 (1999): 40-43. Charles Rosenberg examined the political currency and ideology of coins minted under Alfonso I d'Este in a lecture entitled "Money Talks: Numismatic Propaganda under Alfonso I d'Este," presented at the conference "L'età di Alfonso I" (as in n. 32). See also Vincenzo Bellini, Delle monete di Ferrara (Ferrara: Giuseppe Rinaldi, 1761), 169, 189

84. Richard Brown (as in n. 42), " 'La città festeggiante': The Festival Year," 283-434, and "Investiture, Reception and Entry: The Creation of a Ceremonial Identity," 435-592. See also Richard Trexler, "The Ritual of Celebration," in Public Life in Renaissance Florence (New York: Academic Press, 1980), 215-78; and the political and social connotations of the ceremonial canopy, offering of flowers, and inscriptions in Simone Martini's Maestà as analyzed by C. Jean Campbell, "The Lady in the Council Chamber: Diplomacy and Poetry in Simone Martini's Maesta,”, Word and Image 14 (1998): 371-86.

85. Adrian Randolph, "Regarding Women in Sacred Space," in Picturing Women in Renaissance and Baroque Italy, ed. Geraldine Johnson and Sara Matthews Grieco (Cambridge: Cambridge University Press, 1997), 17-41.

86. Zerbinati, 117: “[1511] Nel detto mese di giugno cominciò a far miracoli la Nostra Dona in un pilastro di preda fatto nuovamente nel bastione della porta di Sotto, nel qual pilastro era l'imagine di Nostra Donna, la testa e volto solamente, qual imagine era sopra la porta e ponte della detta porta di Sotto, e quando fu rovinata e getata tutta in terra quella vernata passata, la detta testa non si ruppe niente, e fu ritrovata così intiera et mostrata al duca nostro e sua signoria fece fare un pilastro in detto bastione e mettervela dentro, dove cominciò a far miracoli assai, poi fu fatta tutta la figura intiera, assetata col suo figliolo in piede, per un depintore il quale disse et attestò che volendo fare il bambino non sapea come fare e poi, tornato da desinare, trovò dove lui fece poi il bambino e la testa del bambino tutto bianco e mostrolo a più persone, e fece il puttino in piedi in quel loco medemo dove mostrava quela biancheza, e dopo fece infiniti miracoli a forestieri assai, li quali venivano a visitar quel loco, et si cominciò a fare un capitello sopra detto pillastro e poi se ne fece un maggiore per potere stare al coperto le persone, concorendone assaissime sì de terriere come de forestiere."

87. For cult images in the Renaissance, see David Freedberg, The Power of Images: Studies in the History and Theory of Response (Chicago: University of Chicago Press, 1989), 110-20.

88. Enrico Preverada, "Note sulle confraternite e luoghi pii a Ferrara dal 1574 al 1611," Ravennatensia 4 (1974): 297-344, esp. 324-25; Mario Marzola Per la storia della chiesa ferrarese nel secolo XVI (1497-1590) (Turin: Società Editrice Internazionale, 1976), pt. 1, 721

89. Zerbinati, 133: “[1513] Alli 8 aprile il messer Antonio Costabili, giudice del comune di Ferrara, fece chiamare li gentilhomini e cittadini assai a casa sua per far conseglio e mettere qualche ordine circa l'entrate et elemosina della Madonna delli Miracoli del bastione della porta di Sotto, delli quali gentilhomini e cittadini ne furno elletti 32 che havessero a governare dette entrate et a fabricare una chiesa, quando serà il tempo, dove al duca piacerà et io fui uno delli detti 32" (On April 8 Sir Antonio Costabili, giudice of the commune of Ferrara, had many gentlemen and citizens called to his home to devise a council in order to make arrangements regarding the entry of and charity for the Madonna of Miracles of the bastion at the Porta di Sotto. Out of those gentlemen and citizens, thirty-two were elected to govern over the said 
entry and the construction of a church, when time permits, and where the duke pleases; and I was one of the aforementioned thirty-two).

90. Guarini, vol. 2, 381-82; Scalabrini, 295.

91. Fedozzi (as in n. 36), 61-62, claims that the donor portrayed in the Lamentation by Giovanni Battista Benvenuti, called Ortolano (Galleria Borghese, Rome) is Antonio Costabili, whom she identifies on the basis of physiognomic similarities with his portrait by Dosso. Ortolano's painting, datable to about 1518, has a provenance from the church of the Madonnina. According to Fedozzi, it was probably housed in a temporary oratory constructed for the Madonna di Porta di Sotto. On the painting and its provenance, see Ballarin, vol. 1, 271-72.

92. Guarini, vol. 2, 361; Scalabrini, 301.

93. Stephen Campbell, Cosmè Tura of Ferrara: Style, Politics and the Renaissance City, 1450-1495 (New Haven: Yale University Press, 1997), 140-41. The origins of Saint George in Ferrara are explored by Antonio Samaritani, "Il culto di S Giorgio a Ferrara," in San Giorgio tra Ferrara e Praga (Ferrara: Gabriele Corbo, 1991), 84-99.

94. Carolyn Walker Bynum, Fragmentation and Redemption: Essays on Gender and the Human Body in Medieval Religion (New York: Zone Books, 1991), 231-35, discusses the symbolic function of the martyr body. It may be worth exploring the possible connection between the Costabili polyptych and a series of altarpieces commissioned in Venice from 1509 to 1511 from such artists as Giovanni Buonconsiglio and Titian, which Alessandro Nova points out were meant as "petitions for protection against the plague" and "simultaneously celebrated the end of the worst of the political threats" to the city; Nova "Giorgione's Inferno with Aeneas and Anchises for Taddeo Contarini," in Ciammitti et al., 53-54.

95. Ronald Lightbown, Mantegna (Berkeley: University of California Press, 1986), 177-84

96. Ibid., 177

97. Costabili was in Mantua on diplomatic missions in 1506 and again in 1509. Clifford Brown has republished a document from the Archivio di Stato of Mantua indicating that on Apr. 11, 1512, Dosso was paid for a painting with eleven figures in the Palazzo di S. Sebastiano, in "The Palazzo di San Sebastiano (1506-1512) and the Art Patronage of Francesco II Gonzaga Fourth Marquis of Mantua," Gazette des Beaux-Arts 129 (1997): 151-58. Vasari, vol. 6, 460, claims that Garofalo worked for two years in Mantua with Lorenzo Costa. Furthermore, in Nov. 1519 Alfonso I d'Este sent both Dosso and Titian to Mantua to study the works of Mantegna owned by Isabella d'Este. The artists' visit is described in a letter to Isabella d'Este by her correspondent Girolamo da Sestola, which was first published by Alessandro Luzio, La galleria dei Gonzaga venduta all'Inghilterra nel 1627-28: Documenti degli archivi di Mantova e Londra (1913; reprint, Rome: Bardi, 1974), 218

98. The authoritative analysis of Augustine's conversion in his Confessions is Pierre Courcelle, Recherches sur les "Confessions" de Saint Augustine (Paris: E. de Boccard, 1950).

99. Antonio Meli, Ordinatione deli monasterii dele monache del ordine de Sancto Augustino, BAF ms Cl.II 8 .

100. Antonio Meli, Libro de vita contemplativa: Intitulato Scala del Paradiso (Brescia: Io. Antonio Morandi da Gandino, 1527). Meli's text is discussed by Samaritani (as in n. 62), 968-75.

101. Meli (as in n. 100), 75r-75v: "Ricordate signore di fare vendetta de quelli homini terreni, duri, e lapidei, gli quali sono stati destructori della mia tropologica Città di Hierusalem: accendendo le mie sensibili passioni e parti sensuali, alla rebellioni della raggione: e destructione della parte mia spirituale. E qual' vendetta debbono dimandare? Non altra che quella qual' dio dice per Isaia profeta. Io mi vindicarò de mei nemici (cio' occidendo et extinguendo in essi lerrore: e sussitando la fede mia operosa) come Augustin expone",

102. The gesture recalls that of the Madonna in Leonardo's Virgin of the Rocks (Musée du Louvre, Paris), for which see Timothy Verdon, "Spiritualità rinascimentale nella Vergine delle Rocce: Saggio di metodo interpretivo," Arte Lombarda, nos. 76-77 (1986): 100-112, esp. 105; and Corine Schleif, "Hands that Appoint, Anoint and Ally: Late Medieval Donor Strategies for Appropriating Approbation through Painting," Art History 16 (1993): 1-32.

103. Ballarin, vol. 1, 274, dates Ortolano's altarpiece to about 1523. The author also makes a visual comparison between Dosso's figure of Saint George and Ortolano's figure of Saint Demetrius (vol. 2, figs. 648, 650).

104. On the representation of spiritual visions, see Paul Barolsky, "The Visionary Experience of Renaissance Art," Word and Image 11 (1995): 174-81; and idem, "The History of Italian Renaissance Art Re-envisioned," Word and Image 12 (1996): 243-50

105. Kaspar Elm, "Augustinus Canonicus-Augustinus Eremita: A Quattrocento Cause Célebbre" in Christianity and the Renaissance: Image and Religious Imagination in the Quattrocento, ed. Timothy Verdon and John Henderson (Syracuse, N.Y.: Syracuse University Press, 1990), 83-107. See the fresco by Benozzo Gozzoli in the choir of S. Agostino in S. Gimignano, which depicts a continuous narrative involving three scenes immediately following Augustine's conversion: Augustine's meeting the Christ Child, his visit to the hermits in Tuscany, and the bestowal of his rule. Significantly, Saint Augustine is robed as an Austin friar, thereby attesting to "the distinctive character of Augustinian monasticism and its origins," as explained by Diane Cole Ahl, Benozzo Gozzoli (New Haven: Yale University Press, 1996), 132.
106. Marjorie Reeves, The Influence of Prophecy in the Later Middle Ages: A Study in Joachimism (Oxford: Clarendon Press, 1969).

107. Ibid., 265; Latin text, 144: “. . . hi crescent et fama eorum devulgabitur. Et predicabunt fidem quam et defendant usque ad mundi consumptionem in spiritu Helye. Qui erit ordo heremitarum emulantium vitam angelorum. Quorum vita erit quasi ignis ardens in amore et zelo Dei ad comburendum tribulos et spinas, hoc est, ad consumendum et extinguendum pernitiosam vitam pravorum."

108. Lanzi, vol. 3, 157: "Lo trovo ne' libri rassomigliato or a Raffaello, or a Tiziano, or al Coreggio; e certamente ha grazia, tinte, chiaroscuro di gran maestro. Ritien però dell'antico stile più di questi altri, ed ha un inventare $\mathrm{e}$ un vestire che trattiene per certa sua novità. E ne' quadri ben mantenuti cresce il suo nuovo per una varietà e arditezza di colori che pur non pregiudica alla unione ed all'armonia" (In books I sometimes find him [Dosso] compared to Raphael, Titian, or Correggio; and certainly he has the grace, tints, and chiaroscuro of a great master. He retains, however, the antico style more so than these other artists, and has a means of invention and a way of portraying drapery that attract for their certain novelty. Also, in his well-preserved paintings there grows an unexampled way of achieving a variety and daring in his colors, which does not compromise their harmony and unity). Compare Lanzi's remarks on Dosso's palette to those of Adolfo Venturi, Storia dell'arte italiana: La pittura del quattrocento (Milan: Ulrico Hoepli, 1914), vol. 9, pt. 3, 935-37: “. . . tutta l'arte di Dosso discende da Venezia, da Giorgio da Castelfranco e da Tiziano, finchè trova una sua propria espressione nella ricchezza altisonante e fastosa dei colori gemmei e dei lumi d'oro" (. . . all the art of Dosso descends from Venice, from Giorgione of Castelfranco and from Titian, whereby he finds his own expression in the rich overtures and sumptuousness of gemlike colors and glimmers of gold).

109. The fundamental study on Alfonso's Book of Hours is Hermann Julius Hermann, La miniatura estense, ed. Federica Toniolo (Modena: Franco Cosimo Panini, 1994), 166-70, 178-83; updated and expanded from Hermann, "Zur Geschichte der Miniaturmalerei am Hofe der Este in Ferrara: Stilkritische Studien," Jahrbuch der Kunsthistorischen Sammlungen des allerhöchsten Kaiserhauses 21 (1900): 117-221. See also Charles Rosenberg, "The Influence of Northern Graphics on Painting in Renaissance Ferrara: Matteo da Milano," Musei Ferraresi 15 (1985-87): 61-72; and the entries by Jonathan Alexander in $L a$ Miniatura a Ferrara dal tempo di Cosmè Tura all'eredità di Ercole de' Roberti, ed. Federica Toniolo (Modena: Franco Cosimo Panini, 1998), 305-11.

110. Alexander (as in n. 109), 311; and idem, "Matteo da Milano, Illuminator," Pantheon 50 (1992): 32-45, esp. 32-33.

111. Julius's beard carried strong imperial connotations, since at that time only princes, nobles, and Jews wore beards, for which see Loren Partridge and Randolph Starn, A Renaissance Likeness: Art and Culture in Raphael's "Julius II" (Berkeley: University of California Press, 1980), 43-47.

112. Mendelsohn (as in n. 14), 104-7, suggested that Matthew 3:11 and Luke 3:16, in which Saint John the Baptist predicts that the Savior will be baptized in the Holy Spirit and in fire, are the sources for this detail.

113. Saint Augustine, trans. William Chase Greene, 1969, 20.21: "Sive igne sive tempestate sive galdio poenam iudicii significat; quando quidem ipsum Dominum quasi ignem dicit esse venturum, eis profecto quibus poenalis erit eius adventus."

114. Baura (as in n. 64), 24r: "Grando et carbones ignis: cioè dio mandarà grandine et carboni de ardente foco, che serano le sanguinose battaglie. . . Et fulgura multiplicavit: Et tanto tempo multiplicarà questi fulguri, cioè queste afflictione in fine a tanto che Conturbavit eos. ...Et apparuerunt fontes aquarum: Et alhora dio farà apparere le fonte dele aque sancte sue, appararà alhora per tutta la chiesa la fonte dela pace, la fonte dela clementia, la fonte dela iustitia, la fonte dela gratia et charità et dela fede, et di tutte le altre virtù."

115. Saint Augustine, Literal Commentary on Genesis, 12.16, in which he speaks of the visions of Isaiah and of John in the Apocalypse as belonging to the spiritual type.

116. Ronald Lightbown, Sandro Botticelli: Life and Work (Berkeley: University of California Press, 1978), vol. 1, 130-33; vol. 2, 94; vol. 1, rev. ed. (New York: Abbeville Press, 1989), 242-47.

117. Savonarola's text appears in translation in Apocalyptic Spirituality: Treatises and Letters of Lacantius, Adso of Montier-en-Der, Joachim of Fiore, the Franciscan Spirituals, Savonarola, trans. Bernard McGinn (New York: Paulist Press, 1979), 192-275, esp. 200. The Dominican maintained close ties with the court of Ferrara: on Aug. 1, 1497, Savonarola presented Duke Ercole I d'Este with an autograph manuscript containing sermons, notes, and annotated poems that he had composed while residing briefly in S. Gimignano; see Giulio Cattin, ed., Il primo Savonarola: Poesie e prediche autografe dal Codice Borromeo (Florence: Leo S. Olschki, 1973). On the issue of eschatological spirituality and the cult of saints in Ferrara, see Gabriella Zarri, "Pietà e profezia alle corti padane: Le pie consigliere dei principi," in Rossi (as in n. 63), 201-37.

118. Previously unpublished sources describing this event include a letter addressed to Isabella d'Este from her correspondent in Ferrara, Girolamo da Sestola, May 3, 1514, Archivio di Stato, Mantua, Archivio Gonzaga, busta 1245: "Illustrissima Signora patrona mia, qui non abiamo di novo so no che trete la saieta in Santo Andrea et dete in tel Crucifiso grande et à butato via la testa e ' 1 busto de meser Domenedio et romase le braze atachate al Crucifiso qual è sopra l'altaro grande. Aspetemo de di in di rezo e spero serà presto. ..."; and "Diario delle cose di Ferrara," BAF ms Cl.I.463, fol. 114: “[May 1, 1514] La 
saetta diede nelle Chiesa di Sant'Andrea, e getto via la testa al crucifisso grande, e diede anco nel Pilastro, dove è il tabernacolo col sacramento. In questo tempo predicava il vespere un frate di questo ordine detto Frate Andrea dalla Barba [Andrea Baura?]."

119. Mario Equicola, "Genealogia de signori estensi," BAF ms Cl.II.349 Equicola, fol 91, describes a comet that hit Ferrara in Borgo S. Angeli on March 4, 1501, which Duke Ercole I d'Este interpreted as a sign from God, and he subsequently erected a church, S. Maria degli Angeli, on the very site where it landed.

120. Studies on Calcagnini's biography and work include Ferrante Borsetti (as in n. 54), vol. 2, 115-22; Giannandrea Barotti, Memorie istoriche di letterati ferraresi (Ferrara: Gli Eredi di Giuseppi Rinaldi, 1792), vol. 1, 287-306; Ernesto Piana, Ricerche ed osservazioni sulla vita e sugli scritti di Celio Calcagnini umanist ferrarese del secolo XVI (Rovigo: A. Conzatti, 1899); Alfonso Lazzari, "Un enciclopedico del sec. XVI: Celio Calcagnini," Atti e Memorie della Deputazione Ferrarese di Storia Patria 30 (1936): 83-164; DBI, vol. 16 (1973), s.v. "Calcagnini, Celio," 492-98; Claudio Moreschini, "Per una storia dell'umanesimo latino a Ferrara," in Castelli (as in n. 61), 168-88; and idem, "Aspetti dell'attività letteraria di Celio Calcagnini," in "In supreme dignitatis ..." Per la storia dell'Università di Ferrara 1391-1991, ed. Patrizia Castelli (Florence: Leo S. Olschki, 1995), 155-72.

121. Garofalo's frescoes are based on Calcagnini's Anteros sive de mutuuo amore, in Celio Calcagnini (as in n. 45), 436-42. On the decoration, see Erkinger Schwarzenberg, "Die Lunetten der 'stanza del tesoro' im Palast des Ludovico il Moro zu Ferrara," Arte Antica e Moderna 26 (1964): 131-50; reprint, "Le lunette della Stanza del Tesoro nel Palazzo di Ludovico il Moro a Ferrara," Atti e Memorie della Deputazione Provinciale Ferrarese di Storia Patria 6 (1967): 45-96; Fioravanti Baraldi, 80-86; Alessandra Pattanaro, "Garofalo e Cesarino in Palazzo Costabili a Ferrara," Prospettiva 73-74 (1994): 97-110.

122. Celio Calcagnini, Carminum libri tres, ed. Battista Pigna (Venice: Vincenzo Valgrisi, 1553), 194-95: "Durus in Alphonsum metuenda exciterat arma / Iulius excussit quom Deus arma manu. / Illa eadem arma Leo rursum est attingere nixus / Sensit et iratos protinus ipse Deos, / Quisquis eris sacro in solio considere iussus / Esto memor pacem muneris esse tui. / Quod si te mala mens regnique insana Cupido / In scelus et rursus in vetita arma trahet, / D scelerum ultores rursus sua tela movebunt, / Discat ut exemplo postera turba tuo."

123. On Saint Maurelius, see M. Tagliabue, "L'anonima Vita latina di San Maurelio vescovo di Ferrara e il De inventione di Matteo Rento," Analecta Pomposiana, 6: Studi monastici (1981): 221-63; and Campbell (as in n. 93), 90-92.

124. Charles Stinger, The Renaissance in Rome (Bloomington: Indiana University Press, 1985), 299-308.
125. Before we speculate on whether or not Dosso visited Rome prior to executing the Costabili polyptych, we should consider the impact of Dosso's early education at the small, erudite court of Mirandola. This was a burgeoning artistic center ruled by the Pico family, which had close political and cultural ties with the Este. Alliances between Mirandola and Ferrara solidified in 1468 with the marriage of Bianca Maria d'Este, daughter of Marchese Niccolò III d'Este, to Galeotto Pico. Mirandola was in political turmoil after Pope Julius II conquered the city on Jan. 20,1511, and expelled the humanist Count Gian Francesco Pico. For a concise history of the relations between the two cities, see Odoardo Rombaldi, "Mirandola dai Pico agli Estensi: Problemi," in Mirandola e le terre del Basso Corso del Secchia dal Medioevo all'eta contempranea (Modena: Aedes Muratoriana, 1984), vol. 1, 29-68. Furthermore, Vasari's claim that Dosso trained under Lorenzo Costa (Vasari, vol. 3, 140), a champion of the "devout style" (maniera devota), merits further investigation. On the maniera devota, see Charles Dempsey, "The Carracci and the Devout Style in Emilia," in Emilian Painting of the 16th and 17th Centuries (Bologna: Nuova Alfa, 1987), 75-87.

126. While ambassador for Ercole I d'Este in Milan, Costabili liberated Boccaccino from prison and sent him to Ferrara with a letter of recommendation (dated Apr. 1, 1497) to the duke. The original text of the letter is reprinted in Alfredo Pueri, Boccaccino (Milan: Ceschina, 1957), 210. An English translation of the letter is available in Creighton Gilbert, Italian Art 1400-1500: Sources and Documents (Englewood Cliffs, N.J.: Prentice-Hall, 1980), $141-42$. Boccaccino was highly celebrated by historians from Vasari on as a pivotal artist who mastered a style that came to be known as antica moderna. Recent studies on the artist include Marco Tanzi, Boccaccio Boccaccino (Soncino: Edizioni dei Soncino, 1991); Alessandra Pattanaro, "La 'scuola' del Boccaccino a Ferrara," Prospettiva, no. 64 (1991): 60-74; and Ballarin, vol. 1, 1-21.

127. Franceschini, 1997, doc. 340. References to Franceschini's discovery of these documents first appeared in Emanuele Mattaliano, "Benvenuto Tisi da Garofalo: Documenti inediti," in Da Borso a Cesare d'Este: La scuola di Ferrara 1450-1628 (Ferrara: Belriguardo, 1985), 170-71.

128. Bovio made a few noteworthy emendations in his manuscript: "Inferni" replaces "Antiqui" in line 2; "Stelliferique" replaces "Occulisque" in line 3; and "quaecunque obducta" replaces "nebulis circumdata quaeque" in line 10. Two important surveys on Marian poetry that are relevant to the context of Bovio's poem are Yrjö Hirn, The Sacred Shrine: A Study in the Poetry and Art of the Catholic Church (London: MacMillan, 1912); and Clelia Maria Piastra, La poesia mariologica dell'umanesimo latino: Repertorio e incipitario (Spoleto: Centro Italiano di Studi sull'Alto Medioevo, 1994). I wish to thank Matthew Roller for clarifying some syntactic points regarding Bovio's Latin. 